(2) norden 



\section{The Nordic Energy Markets and Environment}


The Nordic Energy Markets and Environment

TemaNord 2007:613

(C) Nordic Council of Ministers, Copenhagen 2007

ISBN 978-92-893-1625-5

Print: Ekspressen Tryk \& Kopicenter

Copies: 128

Printed on environmentally friendly paper

This publication can be ordered on www.norden.org/order. Other Nordic publications are available at www.norden.org/publications

Printed in Denmark

\section{Nordic Council of Ministers}

Store Strandstræde 18

DK-1255 Copenhagen K

Phone (+45) 33960200

Fax (+45) 33960202

\section{Nordic Council}

Store Strandstræde 18

DK-1255 Copenhagen K

Phone (+45) 33960400

Fax $(+45) 33111870$

www.norden.org

\section{Nordic co-operation}

Nordic cooperation is one of the world's most extensive forms of regional collaboration, involving Denmark, Finland, Iceland, Norway, Sweden, and three autonomous areas: the Faroe Islands, Greenland, and Åland.

Nordic cooperation has firm traditions in politics, the economy, and culture. It plays an important rol in European and international collaboration, and aims at creating a strong Nordic community in a strong Europe.

Nordic cooperation seeks to safeguard Nordic and regional interests and principles in the global community. Common Nordic values help the region solidify its position as one of the world's most innovative and competitive. 


\section{Content}

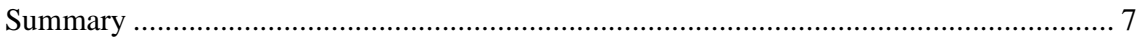

1 Electricity Generation in the Nordic Countries......................................................... 17

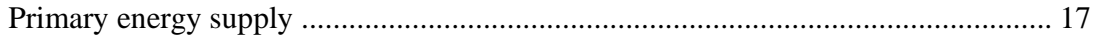

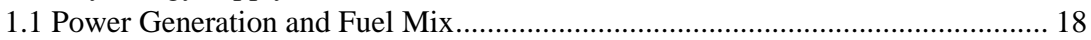

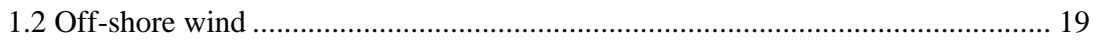

1.3 Promotion of renewable energy production........................................................ 20

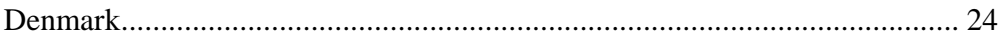

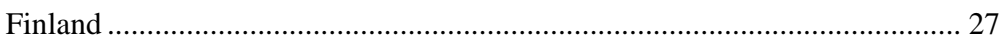

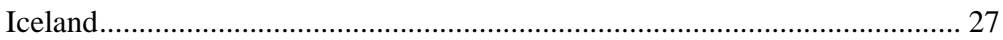

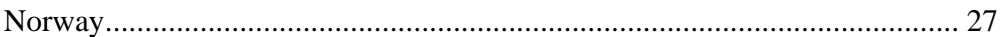

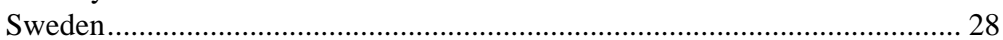

1.4 Support to renewable energy sources through $\mathrm{CO}_{2}$ pricing ................................. 29

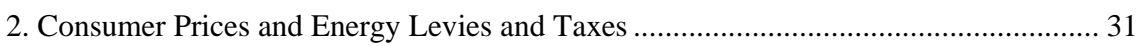

2.1 Energy Consumption in the Nordic Countries...................................................... 31

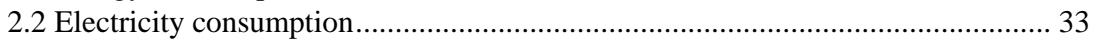

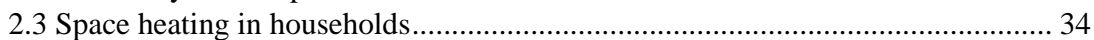

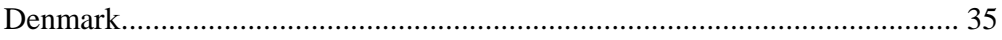

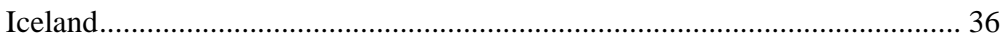

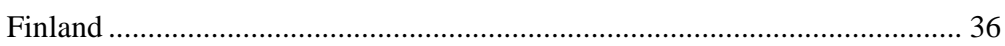

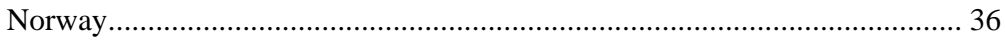

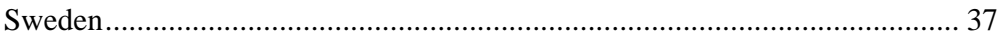

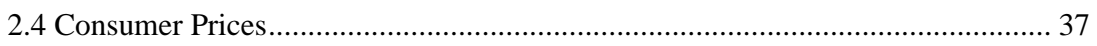

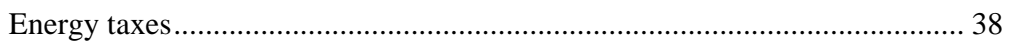

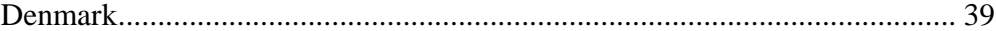

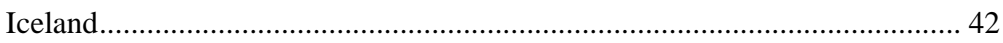

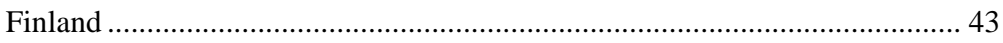

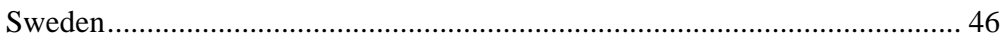

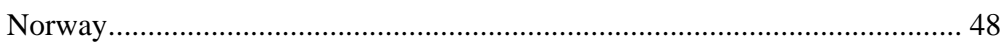

2.5 Electricity supplier switching in the Nordic countries......................................... 50

2.6 Similarities and differences between the Nordic countries.................................. 51

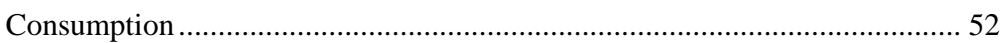

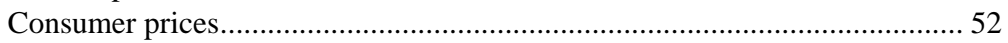

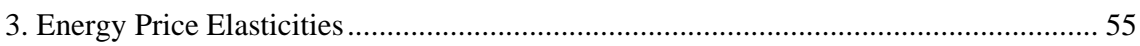

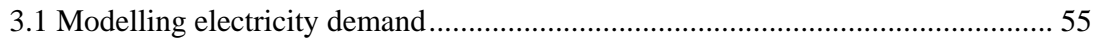

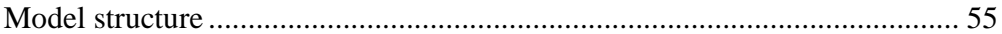

Level of aggregation and functional form .................................................. 57

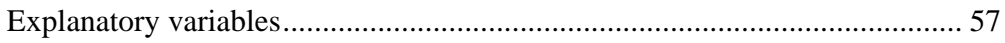

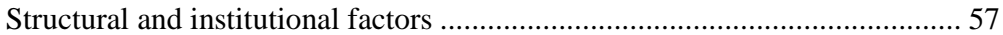

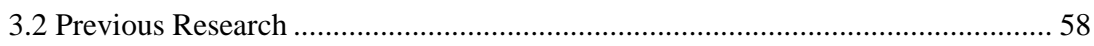

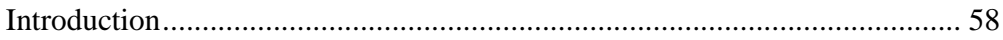

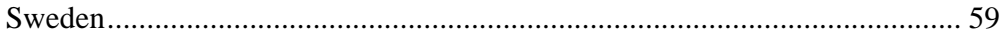

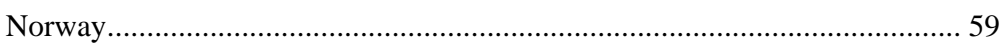

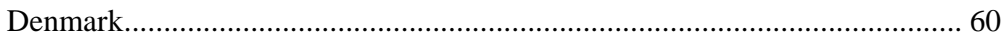

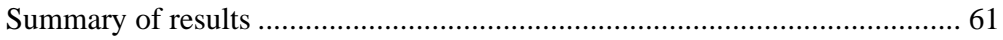

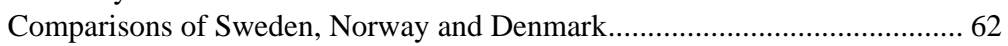

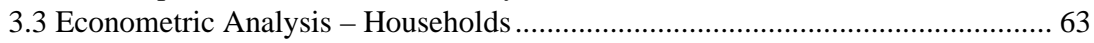

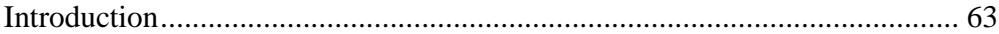

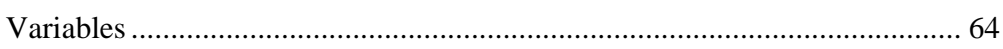

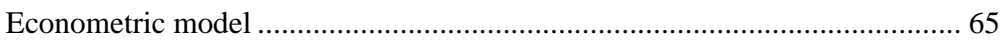




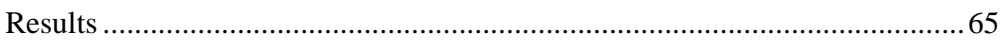

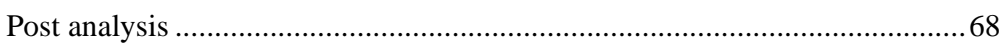

3.4 Conclusions from the econometric analysis ............................................................6 68

4. Environmental effects of energy policy instruments ........................................................ 71

4.1 Historical development of Nordic energy policies............................................... 71

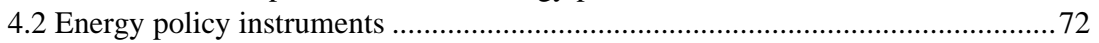

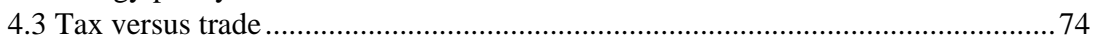

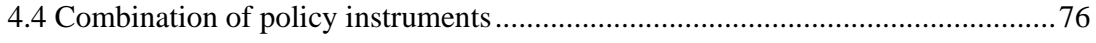

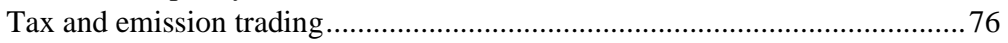

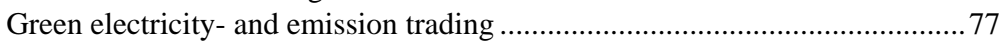

4.5 Policy instruments in relation to the international market..................................... 78

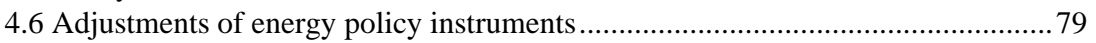

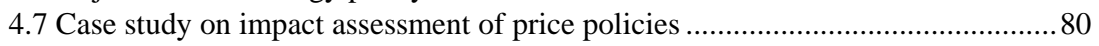

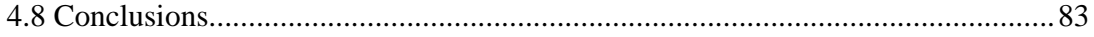

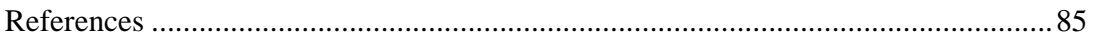

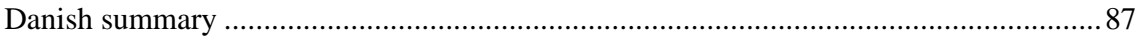

Appendices...................................................................................................... 91

Energy taxes applicable to gas and electricity in the Nordic countries ....................... 91

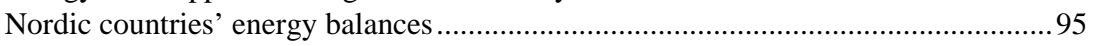

Electricity generation by fuel........................................................................ 95

Final energy consumption by sectors.............................................................99

Electricity consumption per sector, total production and net imports .............100

Primary energy production and consumption ................................................ 102 


\section{Summary}

\section{Background and problem statement}

The Environment and Economy group under the Nordic Council of ministers has called for a report to describe the energy consumption of different Nordic consumer groups. In addition, an overview of the similarities and differences between the energy sectors in the Nordic countries, Denmark, Finland, Iceland, Norway and Sweden, is to be presented. This report sets out the underlying factors for these similarities and differences (e.g. available resources, production and political priorities (financial means)). This is used to discuss the implications on environment and energy use.

Electricity consumption constitutes a very large part of the net energy consumption in the Nordic countries. Therefore, the main focus of this report is on electricity consumption.

The analysis concentrates on the Nordic countries; Sweden, Finland, Norway and Denmark. Iceland is only included in the sub-analyses where it is found reasonable and where data is available.

\section{Findings and main conclusions}

\section{Primary energy supply}

The mix of natural energy resources differs between the Nordic countries. Norway and Denmark have large resources of oil and natural gas. Where Denmark uses almost all their natural gas as domestic consumption, only $1 \%$ of the final Norwegian energy consumption is based on natural gas. The $1 \%$ is the same magnitude as Sweden that does not have any petroleum resources.

Also the share of district heating and combined heat and power production (CHP) differs. Denmark has the largest share with $63 \%$ of the electricity production coming from CHP plants for district heating.

The foundation of the present fuel mix is historically determined. Natural resources and political priorities have formed the energy sector through the last century. Especially the development of the griddependent energies have been driven by central planning and heavily influenced by political priorities - and political priorities have naturally been affected by the endowment of domestic energy resources. This group of energies includes electricity, district heating and natural gas. 
Renewable energy has gained large support since the early 1990ies. Especially in the electricity sector, small scale renewables have been given priority whereas the supply side of conventional power generation has been liberalised.

Large natural resources of geothermal energy in Iceland and hydropower in Norway, Sweden and Iceland made it natural to include these resources in the fuel mix.

\section{Power generation and fuel mix}

The domestic fuel mixes in the power supply differ between the Nordic countries (see figure 1). Coal, natural gas and wind energy are the main energy resources for power generation in Denmark. Norwegian power generation is almost solely based on hydropower. Swedish power generation is based on nuclear and hydropower and Finish power generation is based on a mix of the different energy resources. Iceland has a relatively large share of geothermal electricity production in addition to hydropower.

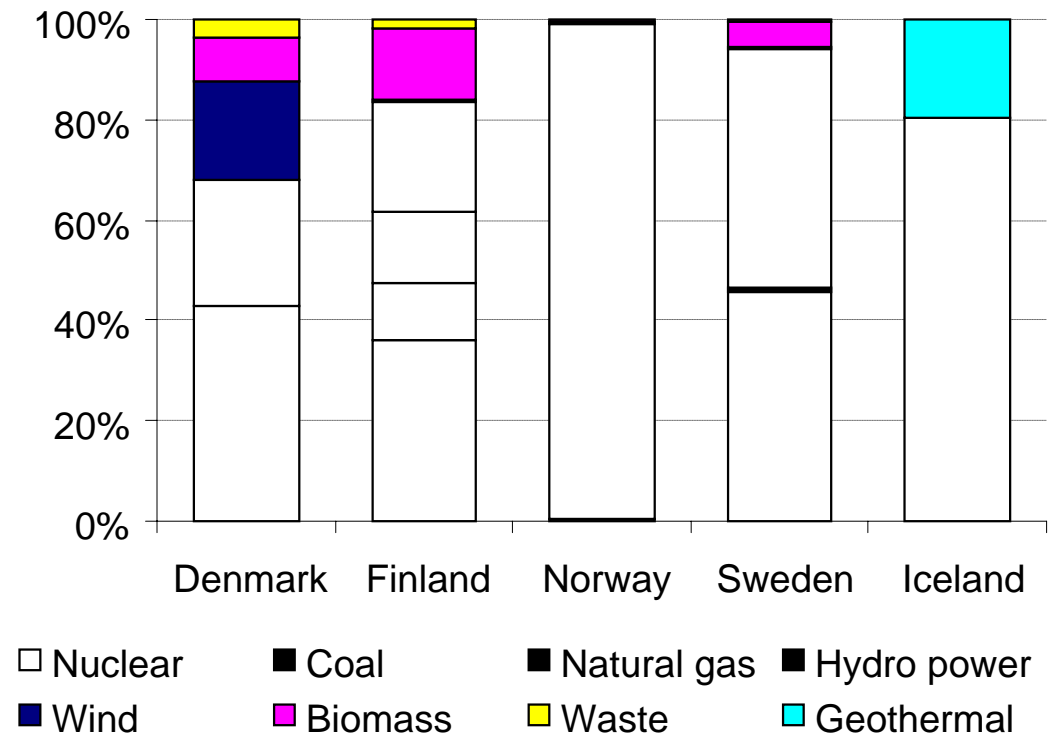

Figure 1: Relative fuel mix in the Nordic power generation. Source: Nordel 2005.

The large use of fossil fuels in power generation in Denmark and to some extent also in Finland implies that the environmental effects in terms of green house gas emissions from electricity supply are much larger in these countries than in the other Nordic countries. 


\section{Energy consumption}

How does the energy consumption differ between the Nordic countries?

In the Nordic countries the wholesale price for fossil energy follows the international prices. Due to the large amount of hydropower and nuclear the wholesale price for electricity is low compared with other EU countries. However, the Nordic countries have some of the highest energy taxes within the EU/EES (European Economic Space ${ }^{1}$ ) area. In spite of this the energy consumption per capita is in general higher in the Nordic countries than in the rest of the EU, and the energy intensity of GDP (energy consumption per unit of GDP) is high. Only Denmark has an energy intensity that is close to the EU average.

Total gross energy consumption in the Nordic countries differs from sector to sector. This is shown in the Figure 2 below. The energy consumption of primary industries is relatively low in most Nordic countries, with the exception of Norway. The industrial sectors in Norway, Sweden and Finland account for a relatively large part of the energy consumption (27-45\% of total national consumption) while the same sectors in Denmark consume only $14 \%$ due to a very small energy-intensive industry.

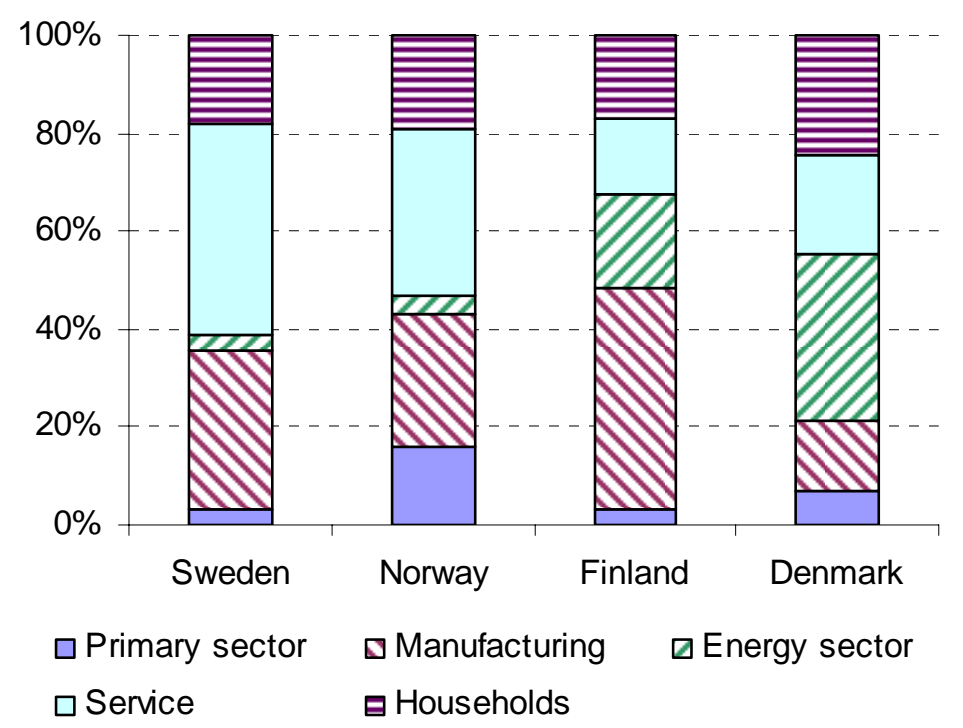

Figure 2: Gross energy consumption per sector (in \%). Source: EuroStat 1999.

\footnotetext{
${ }^{1}$ http://www.unece.org/press/pr2003/03ireedd p01e.htm
} 


\section{Electricity consumption}

Does electricity consumption have the same profile in all of the Nordic countries?

Electricity consumption per capita in the Nordic countries differs a great deal from country to country (Figure 3). Throughout the last decade Denmark has had relatively low and constant electricity consumption per capita, and in spite of a substantial growth in Danish GDP, electricity consumption has stayed at a constant level.

Norway has a relatively high level of electricity consumption per capita. This is especially due to the use of electric heating of houses and a relatively large power intensive industry.

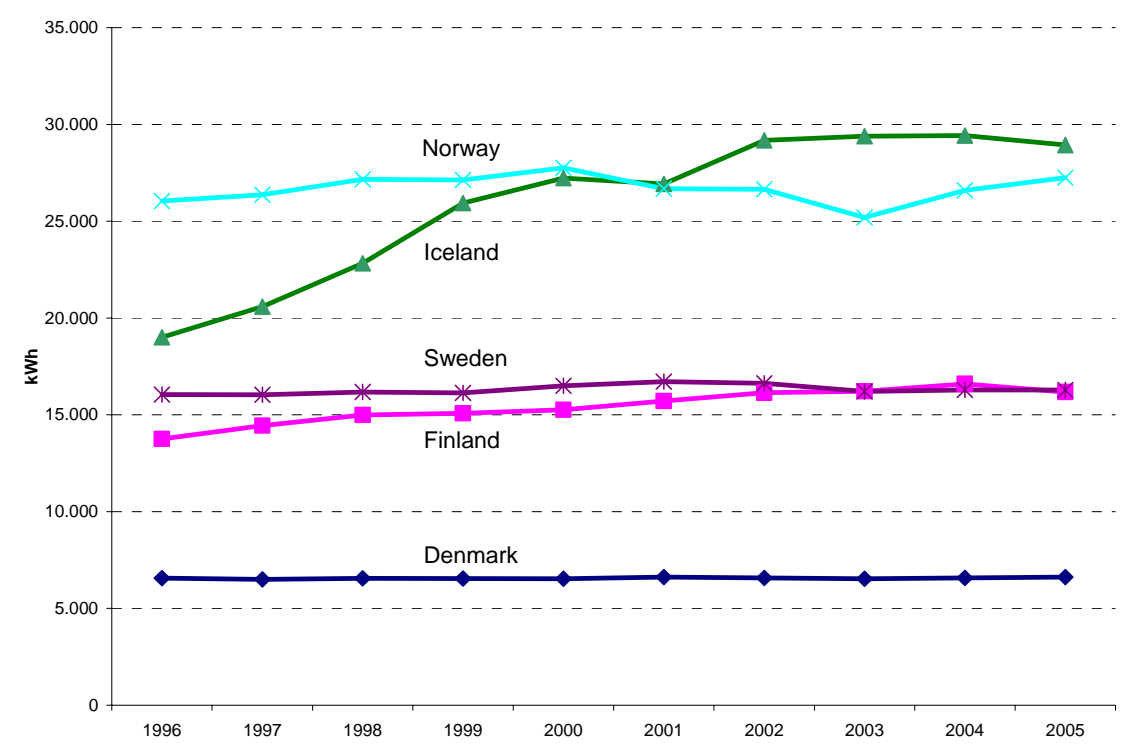

Figure 3: Total electricity consumption per capita in the Nordic countries. Source: Nordel 2006.

Electricity consumption per capita in Iceland increased a great deal in the 1990ies but has remained at the same level since 2002. The increase in consumption was especially due to a growing power-intensive industry particularly aluminium production - and low electricity prices.

\section{Electricity prices}

Have the Nordic consumers faced different trends in electricity prices?

In order to compare the electricity prices for households in the Nordic countries we use the Harmonised Index of Consumer Prices (HIPC). The HIPC for electricity is a measure of the electricity price that households face, i.e. including taxes, VAT and distribution fees. In the Figure 4 we 
have adjusted the HIPC series for electricity by the inflation observed in the HIPC for all goods in each country.

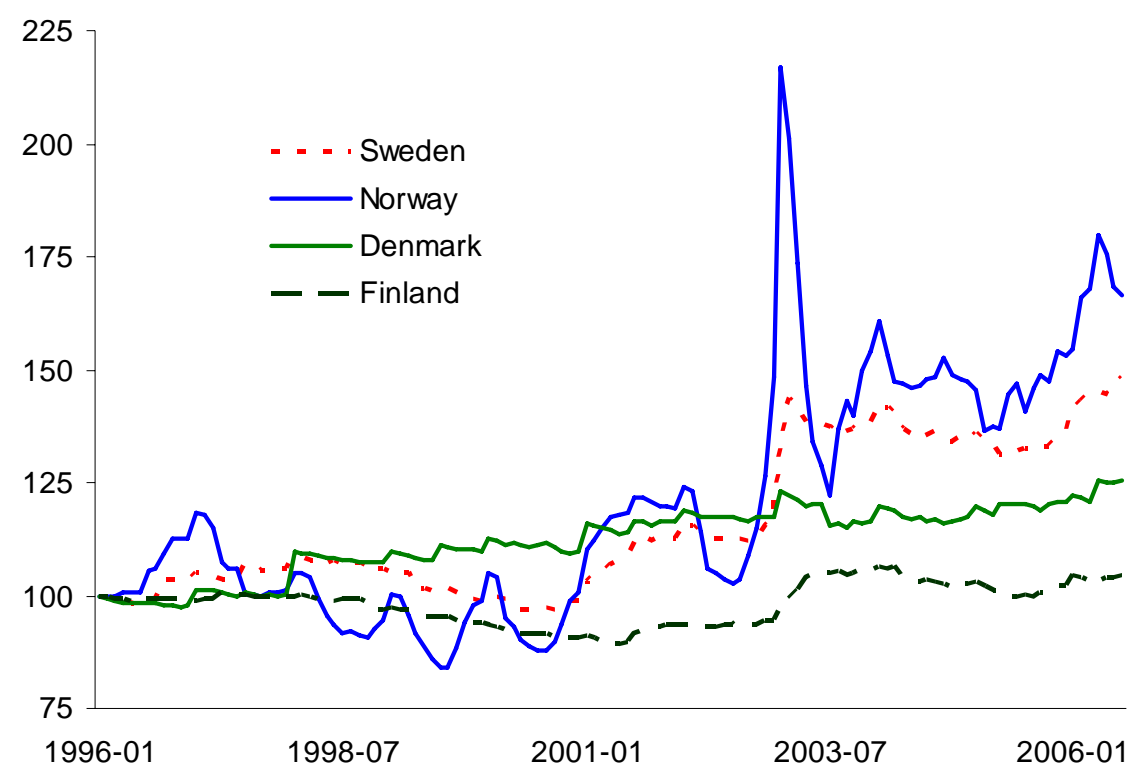

Figure 4: Development of the HIPC for electricity, Source: Eurostat.

All the HIPC indexes for electricity show a positive trend starting around 2002. Measured over the entire period from January 1996 to July 2006 electricity prices increased in all of the four Nordic countries. However, the magnitude of the price increase differs substantially between the four countries. In total, the electricity price in Norway increased by almost $70 \%$ over the period, whereas the corresponding price increase amounted to less than $5 \%$ in Finland. In addition, the volatility of the electricity price index seems to be considerably higher for Norway than for the other Nordic countries.

The small variations in the HIPC of the other countries, especially Denmark, are mainly due to a high level of energy levies and taxes with a flat rate for household. In Denmark, the wholesale electricity price only accounts for $15 \%$ of the consumer price for households. The remaining $85 \%$ are grid payments, taxes and VAT. Due to a flat rate for these taxes any fluctuations in the wholesale electricity price only gives minor fluctuations in the consumer price for households. In other words, in a country like Denmark the household consumers only observe small variations in the consumer prices for electricity. 


\section{Econometric analysis}

How do the Nordic household consumers react to changes in the consumer prices?

In order to answer these questions we need to know whether demand for electricity is price elastic. To obtain comparable estimates of the price elasticities on the Nordic electricity market, we conduct an econometric analysis. We apply a simple log-linear model on monthly aggregated data from the period January 1996 to July 2006 with the objective to estimate short-run price elasticities.

The figure below shows the 95\% confidence interval for the estimated price elasticities in the four Nordic countries.

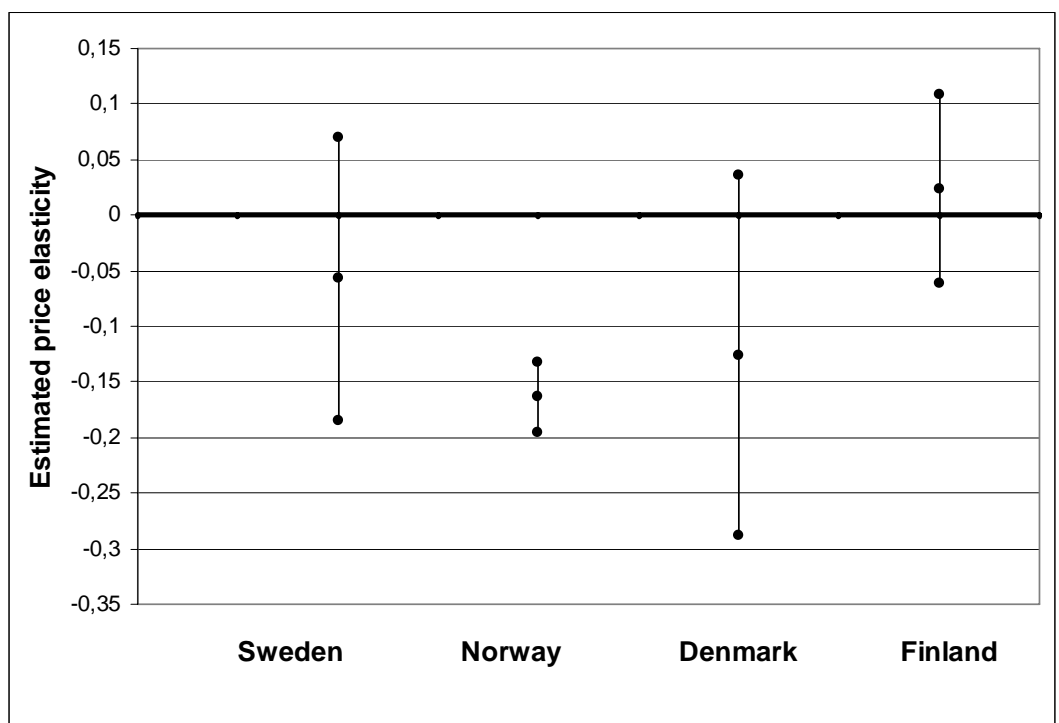

Figure 5: A 95\% confidence interval for the estimated (monthly) electricity price elasticities. Source: own estimates.

The confidence interval is a measure of the accuracy of the estimate. The figure clearly shows that the estimate for confidence interval for Norway is smaller than for the other countries. This illustrates that the price elasticity of electricity demand can be determined with greater certainty for Norway than for the other countries. In addition, the point estimate of the Norwegian price elasticity is lower than the other point estimates. This result suggests that the Norwegian consumers are the most price sensitive consumers on the Nordic electricity market.

In fact, the only price elasticity that has the expected sign and is significantly different from zero is the estimated price elasticity for Norway; the estimated price elasticity is -0.16 . In other words, in Norway, a $1 \%$ increase in the consumer price for electricity, results in a $0.16 \%$ reduction in the electricity consumption. The significant price elasticity in Norway compared to the other Nordic countries may be due to the large amount of electric heating in Norwegian households. This implies that electricity 
counts for a relative large part of the energy budget for households. The share of electricity in the other countries is much lower (see Figure 3).

Based on the analysis, we cannot determine whether, nor to what extent, the electricity consumers in the other Nordic countries are sensitive to changes in the consumer prices for electricity. However, results from an extended analysis indicate that electricity consumption in Sweden does react negatively to increases in the price of electricity, but with at least a six month delay.

\section{Similarities and differences between the Nordic countries}

The above descriptions of consumption and energy prices have shown that similarities and differences do exists between the Nordic countries. However, comparing consumption and prices across different countries is a difficult task. Many underlying factors are not included in the comparison but can be part of the explanation for the differences observed. Examples of such factors are differences in market structure, supply and production conditions, available resources, and historical and energy policy issues. In addition, administrative obligations on the consumption of national fuels or energies may influence the final consumer price, e.g. the Danish mandatory connection to district heating in certain public supply areas and the priority to distributed electricity generation (smallscale CHP and renewable energy). Therefore, the interpretation of the comparisons should be made with caution.

\section{Consumption and consumer prices}

In order to understand the differences in prices and consumption, the structure of the energy markets in the different countries must be taken in to account.

The consumer price level (especially for households) varies considerably between the Nordic countries (Table 1). The consumer price is almost three times higher in Denmark than in Norway.

Table 1: Consumer price level for electricity to households in the Nordic countries and the relative share of energy taxes and VAT.

\begin{tabular}{lrr}
\hline & Consumer price level cent $€ / \mathbf{k W h}$ & Share of VAT and energy taxes \\
\hline Denmark & 24 & $57 \%$ \\
Sweden & 13 & $42 \%$ \\
Finland & 12 & $24 \%$ \\
Norway & 8.5 & $33 \%$ \\
\hline
\end{tabular}

As much as $57 \%$ of the consumer price for electricity to households in Denmark is energy taxes and VAT. In Finland only $24 \%$ of the consumer price originates from energy taxes and VAT. 
Low electricity prices in the last century based on ample access to low cost hydropower resources caused the households in Norway and partly also in Sweden to use electric panels for space heating (see the historical development of prices in the Appendix). This explains why electricity consumption in the household sector is larger in Norway and Sweden than in a country like Denmark, where the use of electric space heating is limited.

In addition, the shift in demand between fuels is highly dependent on the availability of substitutes. The price elasticity of electricity demand should increase with increasing availability of substitutes to electricity. Studies of the Nordic markets indicate that Danish households do not substitute between different energy sources for heating purposes, while Norwegian households do. This difference between Denmark and Norway originates from differences in institutional settings in the two countries. Denmark and Norway are very similar societies in terms of the organization of the society, but there are large differences concerning energy resources, regulation of the energy market and industry structure. Norwegian energy policy imposes few restrictions on the households with respect to choice of space heating equipment. Whereas in a country like Denmark, the priority to district heating and natural gas gives restrictions to the use of alternative space heating equipments. The Norwegian households therefore often have several sources of heating equipment available.

It is reasonable to assume that access to substitutes explains the higher electricity price elasticity in Norwegian households (Figure 5). Previous studies show that almost $90 \%$ of the Norwegian households have the possibility to substitute between different energy sources for heating purposes. In Sweden, 22\% of the households have both electric and fossil based builders. In Denmark, however, the energy market has been submitted to extensive regulation and Danish households typically only have access to one type of heating equipment. In Denmark, 65\% of the households do not have any possibility to substitute between energy types for heating purposes.

The dominating fuel or technology for space heating in households vary substantially between the Nordic countries, from geothermal in Iceland, electricity in Norway, to district heating in Denmark.

The prices for district heating are often regulated and linked to electricity and fuel prices. Due to a limited amount of price series for district heating it is very hard to compare the prices and to make an interpretation of the differences.

However, very stable district heating prices are observed for all countries although the price levels have been slightly increasing. This is mainly due to the fact that district heating prices are regulated based on average prices of alternative fuels and official price indexes. This implies that the short term fluctuation in the prices for alternative fuels is not seen in the price for district heating. 
In conclusion, the level of regulation of the energy market influences the availability of substitutes, which in turn influences the price elasticity. From an energy policy point of view, this implies that using pricing policy to discourage household energy use should be more successful the less regulated the energy market is. For demand to be elastic, two conditions must be in place; Consumers must have access to alternatives (fuels or technologies), and price changes must be reflected in end-user prices.

\section{Energy taxes and the environment}

As a consequence of national policy instruments in combination with international markets, policy goals and instruments in one country can influence conditions in a neighbouring country. Therefore, Nordic cooperation in energy policy design may play an important role although there are differences in goals and the overall policy development.

The Nordic electricity market offers some illustrative examples: Green electricity certificate systems and subsidy schemes for renewable energy sources have reduced the need for investments in Nordic electricity production capacity. On the other hand, nuclear phase outs within Sweden increased the need for further investments in power production.

In relation to the Emission trading scheme (ETS), different allocation rules for new generation capacity in the Nordic countries, creates different investment incentives and distorts competition between the countries, as do different support schemes to renewable generation capacity.

Coordinated or common energy policies require that the underlying energy markets are well functioning. The Nordic Nord Pool electricity market is the best functioning multi-national power market in the world. This gives a good foundation for increased efficiency by implementing common Nordic energy policies - if it cannot work in the Nordic countries it will probably not work elsewhere.

A few years ago Norway and Sweden planned to create the first binational green electricity certificate market. The underlying political process and other policy co-operations should have given the Nordic countries a lot of experiences to build on for the further process.

\section{Can energy taxes be used to reduce CO2 emissions?}

The Nordic countries have applied energy-related taxes for decades. The purpose of energy taxation has primarily been fiscal, but the taxes have nevertheless had an impact on the use of energy and hence the $\mathrm{CO}_{2}$ emissions as well. In addition to taxes, subsidies to renewable energy sources have played a major role as political instrument to reduce the $\mathrm{CO}_{2}$ emission level.

Studies show that policy measures like the ETS, support for renewables and energy taxes all have a significant effect on the $\mathrm{CO}_{2}$ emission level. Where renewables support promotes extended use of renewables, 
taxation of energy and emission trading schemes, like the ETS, internalize the cost of emission in production and utility functions. The internalization will ideally mean increased prices and a reduction in demand depending on price elasticities, technology improvements and the availability of cost-efficient emission reductions options.

Demand for electricity in the Nordic countries is, as we show, not very price elastic in the short-run, but the emission level can nevertheless be affected under the ETS. Emissions reductions will accrue from e.g. technology improvements, fuel switching in the energy sector or increased import of energy intensive goods into the EU.

Policy measures like the ETS and energy taxes will result in an overall increase in energy prices and prices of energy-intensive goods via higher production costs. The price increase on goods happens according to the rate of pass-through of the price of $\mathrm{CO}_{2}$ allowances.

According to the results from our econometric analysis the short-term effect of a price increase on energy services is that energy demand in Norway alone will decrease significantly. The implications in the other Nordic countries are small in the short-term. However, it is likely that consumption adjustments will happen in the long-run in all Nordic countries. It is likely that consumers will adjust their stock of electric appliances and/or the energy efficiency of these to the prevailing price of electricity in the long-run. It is thus reasonable to assume that the long-run price elasticity is negative in all of the Nordic countries. Price effect on demand changes are in other words expected to contribute to emission reductions.

Our impact analysis of the determined elasticities estimates that a $10 \%$ increase in the end-user prices for electricity in the Nordic countries implies a reduction of around 9 million tonne $\mathrm{CO}_{2}$ in the short run and around 14 million tonnes $\mathrm{CO}_{2}$ in the long run. However, these results are only for illustrative purpose due to the uncertainties about the "real" elasticities.

A previous study (Andersen, Enevoldsen and Ryelund, TemaNord 2006:528) has estimated the energy elasticities in ten industrial sectors in Norway, Sweden and Denmark, and for five different fuels. They find that for the other fuels (oil, coal and waste energy) the own price elasticity is much higher than for electricity. This could indicate that carbon energy taxes will induce considerable reduction in energy consumptions if the taxes are exposed on these fuels. 


\section{Electricity Generation in the Nordic Countries}

\section{Primary energy supply}

Norway is a major producer of oil and natural gas and the third largest net exporter of oil \& gas worldwide (accounting for $25 \%$ of EU natural gas imports). In spite of the large natural gas resources, only $1 \%$ of the final Norwegian energy consumption onshore is based on natural gas. However, natural gas is used in the oil industry at the drilling rigs. Onshore, only one natural-gas based electricity plant is under construction and four more has received licenses. The Norwegian power supply system is based on hydropower.

Denmark also produces oil and gas and is self-supplied with a small net export of oil products. Denmark has a thermal dominated electricity supply system with around $25 \%$ of electricity generation from natural gas and $42 \%$ from imported coal. Denmark is also characterised by a high rate of combined heat and power (CHP) for district heating - up from $37 \%$ in 1990 to $63 \%$ in 2005.

Sweden has no petroleum resources and only $1 \%$ of the total Swedish energy consumption is based on natural gas. However, Sweden has large biomass resources. The Swedish power system is mainly based on hydro and nuclear power.

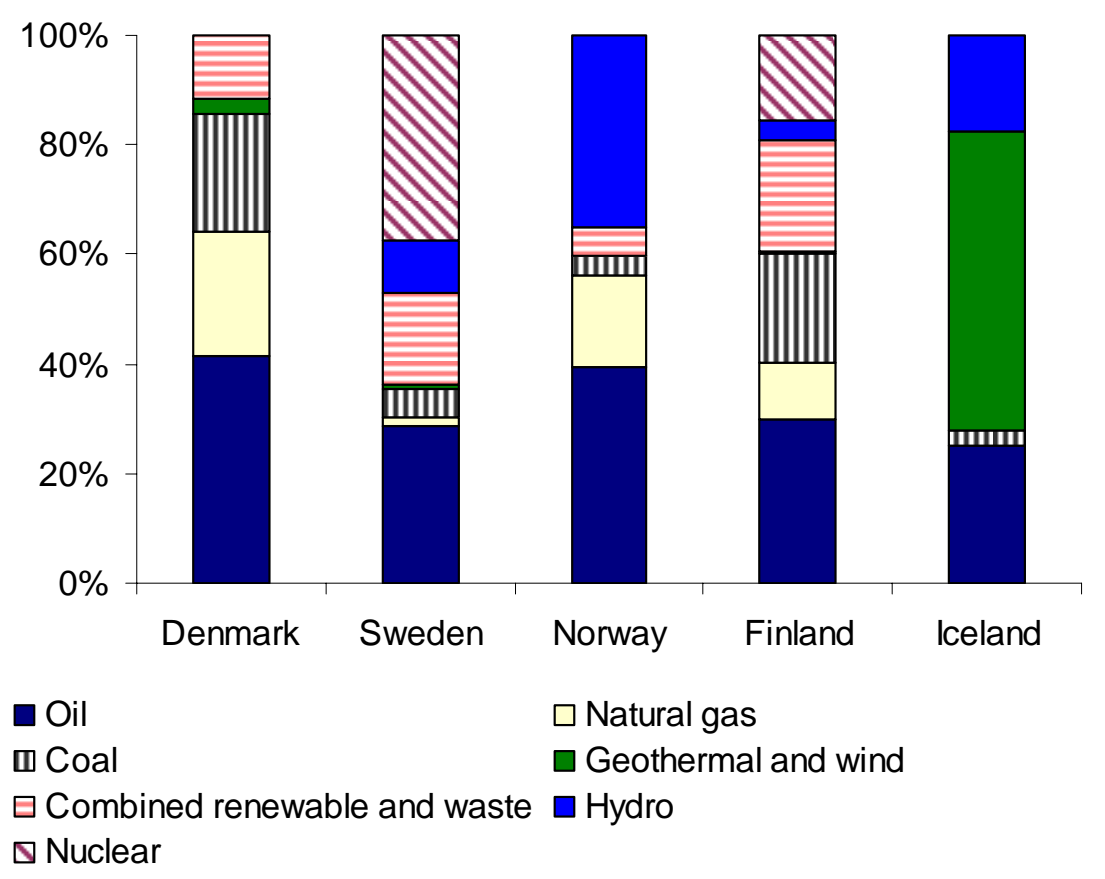

Figure 6: Share of total primary energy supply in 2004. Source: IEA. 
Finland has a very differentiated fuel mix. Iceland has large geothermal and hydro energy resources. In 2005 was 55\% of the gross energy consumption geothermal energy. 16\% were hydropower and 26\% was imported oil and 3\% was imported coal (Figure 6).

\subsection{Power Generation and Fuel Mix}

The national power sectors and the fuel mix differ between the Nordic countries. Coal, natural gas and wind energy are the main energy resources for power generation in Denmark. Norwegian power generation is almost solely based on hydropower. Swedish power generation is based on nuclear and hydropower and Finish power generation is based on a mix of the different energy resources. Iceland has a relatively large share of geothermal electricity production in addition to hydropower.

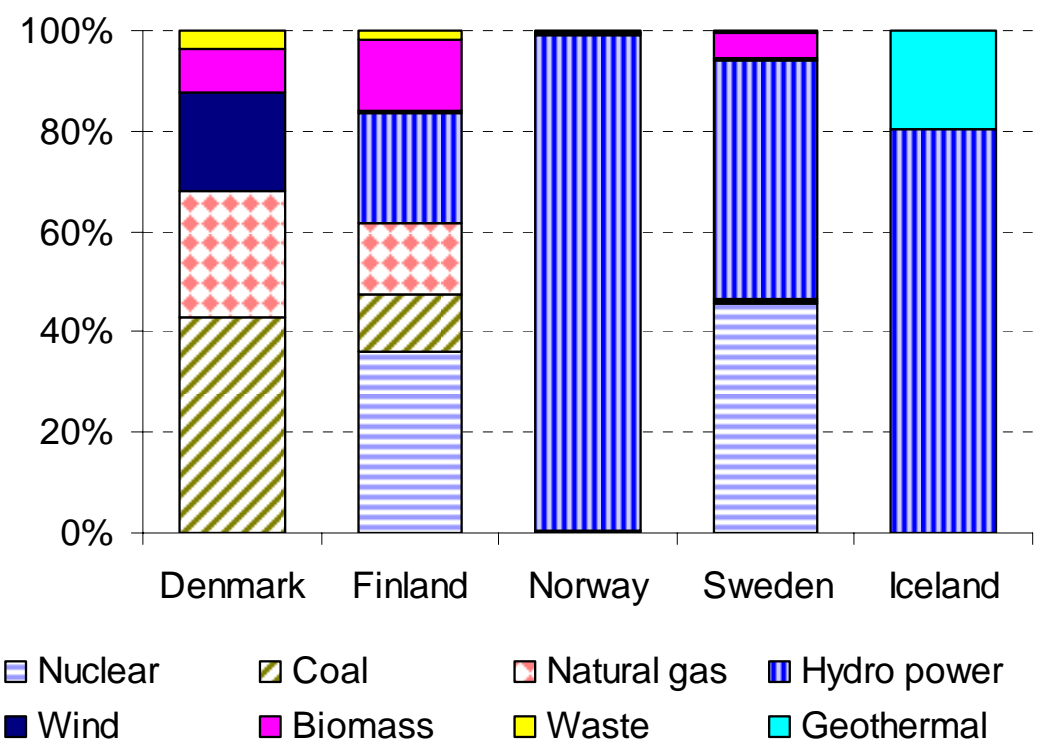

Figure 7: Relative fuel mix in the Nordic power generation. Source: Nordel 2005.

The large use of fossil fuels in power generation in Denmark and to some extent also in Finland implies that the environmental effects in terms of green house gas emissions from electricity supply are much larger in these countries than in the other Nordic countries.

Electricity generation in Denmark is split between traditional production and 'prioritised production', the latter covering mainly renewable electricity based on wind power, biomass and small-scale distributed combined heat and power (CHP).

Almost all the central power generation in Denmark is based on large CHP plants connected to the district heating systems. Similarly, half of the distributed generation is made on CHP plants. 
At present, as a result of earlier agreements, the distribution system operators are obliged to purchase the prioritised production at fixed, high billing prices - hence the term 'prioritised production'. For renewables, the priority rule is combined with a fixed feed-in tariff; for distributed CHP there is a priority rule and a price premium in addition to the market price in place.

In Norway $99 \%$ of total electricity production is hydropower (normal precipitation year production is $121 \mathrm{TWh}$, installed capacity $28300 \mathrm{MW}$ in 1000 large and small plants) which is equal to $50 \%$ of total energy consumption. The total large scale hydropower potential is 205 TWh with an additional small-scale potential of $25 \mathrm{TWh}$.

In Sweden $40-50 \%$ of the total electricity production comes from hydropower (around 67 TWh in normal years), around 50\% from nuclear power and only around 7\% from other sources (of which half is biomass).

\subsection{Off-shore wind}

Within EU and in some of the Nordic countries off-shore wind has gained massive political support during the last few years and political support to a large deployment of wind parks implicate that wind energy will obtain a relatively large share of the renewable electricity supply in the future.

Both in the EU (EU COM(2007)1) and in the Nordic countries, large off-shore wind parks are seen as one of the key new renewable energy sources (together with increased use of biofuels in the transport sector) necessary to reach ambitious energy and environmental goals.

At present a political strategy ${ }^{2}$ has been made in Denmark that will increase the use of wind power from the present $20 \%$ to $50 \%$ of the electricity consumption in 2025 (corresponding to 8\% of the total energy use in Denmark). Possible locations with a total potential of 4600 MW have been identified (with an estimated production of $18 \mathrm{TWh} /$ year).

Adaptations of similar goals are being debated in Sweden and Norway. Norway has large unused wind resources. Table 2 below gives an overview of the planned deployments of wind parks in the Nordic countries.

\footnotetext{
${ }^{2}$ Energistyrelsen, En visionær dansk energipolitik 2025, januar 2007.
} 
Table 2: Already planned and operating off-shore wind parks in Scandinavia. Source: Offshore Center Danmark ${ }^{3}$

\begin{tabular}{|c|c|c|c|c|}
\hline & Name & Status & Capacity [MW] & Completion Year \\
\hline \multirow[t]{15}{*}{ Denmark } & $\begin{array}{l}\text { Frederikshavn } \\
\text { Frederikshavn II }\end{array}$ & $\begin{array}{l}\text { In Operation } \\
\text { Planned }\end{array}$ & 7.6 & 2003 \\
\hline & Grenaa-harbour & Cancelled & 8 & On hold \\
\hline & Horns Rev & In operation & 160 & 2002,12 \\
\hline & Horns Rev - II & Consented & 233,5 & 2009 \\
\hline & Kriegers Flak & Under consideration & 455 & \\
\hline & Kriegers Flak II & Under consideration & $600-700$ & \\
\hline & Middelgrunden & In Operation & 40 & 2001, 03 \\
\hline & Rødsand & In Operation & 166 & $2003,07-27$ \\
\hline & Rødsand II & Consented & 200 & 2009 \\
\hline & Rønland & In Operation & 17 & 2003, early \\
\hline & Rønland II & Planned & & \\
\hline & Rønland III & Planned & & \\
\hline & Samsø & In Operation & 23 & 2003 (late 2002) \\
\hline & Tunø Knob & In Operation & 5 & 1995 \\
\hline & Vindeby & In Operation & 5 & 1991 \\
\hline \multirow[t]{3}{*}{ Norway } & $\begin{array}{l}\text { Havsul I } \\
\text { Havsul II }\end{array}$ & $\begin{array}{l}\text { Planning } \\
\text { Planning }\end{array}$ & $\begin{array}{l}350 \\
801\end{array}$ & \\
\hline & Havsul III & On hold & 450 & \\
\hline & Havsul IV & Planning & 350 & \\
\hline \multirow[t]{10}{*}{ Sweden } & Bockstigen-Valor & In Operation & 2.5 & 1998 \\
\hline & Klasarden & Planned & 44 & $2007 ?$ \\
\hline & Kriegers Flak & Planned & $500-640$ & $2010 ?$ \\
\hline & Kårehamn & Planned & 50 & \\
\hline & Lillgrund & Under consideration & 110 & 2007 , fall \\
\hline & Norgersund & Out of operation & 0.22 & 1990 \\
\hline & Skabbrevet & Planned? & 54 & $2010 ?$ \\
\hline & Utgrunden & In Operation & 10 & 2000,10 \\
\hline & Utgrunden II & Planned? & $72-90$ & 2007 \\
\hline & Yttre Stengrund & In Operation & 10 & 2001, 09 \\
\hline
\end{tabular}

\subsection{Promotion of renewable energy production}

The use of renewable energy sources in the fuel mix is mainly due to natural resource endowments, subsidies and policy priorities. The support for renewable energy sources is gaining more and more importance both on an EU level and in the Nordic counties. In 1997, the European Union started working towards a target of a $12 \%$ share of renewable energy in gross domestic consumption by 2010, representing a doubling compared to 1997. In 2001, the EU Member states (MS) adopted voluntary targets to be reached by the latest in $2010 .{ }^{4}$ The $12 \%$ renewable energy target in gross

\footnotetext{
${ }^{3}$ http://www.offshorecenter.dk/offshorewindfarms/

${ }^{4}$ Directive 2001/77/EC
} 
energy consumption corresponds to generating $21 \%$ of the overall electricity consumption in the EU from renewable energy sources by 2010.

The $12 \%$ target is unlikely to be met. Based on current trends, the EU will not exceed $10 \%$ by 2010 . This is considered as a policy failure (EU COM(2006)848final). In 2007, the EU adopted a mandatory target to increase the EU share of renewable energy to $20 \%$ of the gross energy consumption by 2020 (EU $\operatorname{COM(2007)1).~Individual~targets~for~the~}$ Member States and national allocation plans for sub targets for the electricity, transport (biofuels) and heating sectors are yet to be set (possibly within 2007).

A quantitative guess is that the $20 \%$ target will translate into an electricity sector target of around $34 \%$ of gross electricity consumption for 2020. The transport sector will get a mandatory target with minimum $10 \%$ of the fuels having to be biofuels in 2020 . At present, there are no guesses for the required use of renewables in the heating and cooling sector for $2020 .^{5}$

Along with this process, all the Nordic countries have supported electricity and heat generation from renewable energy sources during the $21^{\text {st }}$ Century. ${ }^{6}$ However, the national measures to support renewable energy differ between the different Nordic countries.

The status of renewable energy development in each of the Nordic countries and in the individual EU Member States is a result of a complex interplay of EU legislation, national policies and specific conditions (e.g., fuel mix, market characteristics) in the respective countries.

The three Nordic EU Member States (Denmark, Sweden and Finland) are directly influenced by the EU directives whereas Iceland and Norway are only indirectly influenced via the EES treaty. The Renewable Energy Directive (Directive 2001/77/EC) envisages national support schemes to be subject to review and evaluation by the Commission. According to the principle of subsidiarity, the EU leaves the implementation of the Directive to the discretion of the Member States so that the latter can apply policy measures which best accommodate their national circumstances.

In 2007 a new revision report from the EU Commission will be made (no later than October 2007). It is expected that a roadmap towards harmonised support systems will be presented (EU COM (2006)848final).

A harmonised support system in the EU will have large effects on the design and functioning of the Nordic systems as well as on the actual deployment of renewable energy technologies in the Nordic countries. Examples of possible effects are on the national or international future "use" of the large wind resources in Norway and the biomass resources in Sweden and Finland.

\footnotetext{
${ }^{5}$ A shift toward geothermal heat pumps and other more energy efficient appliances in the heating and cooling sector can result in an increased use of electricity.

${ }^{6}$ Except of Iceland
} 
However, at present there are no common standards for national policies. Member States apply different support schemes, from direct and indirect support to market oriented mechanisms.

The predominant support scheme in the majority of the EU countries is a feed-in tariff (Figure 8). Apart from these support systems, a number of EU countries have additional forms of support in place. E.g. Denmark has a feed-in tariff system for small, on-shore wind turbines, but a tendering system for off-shore wind power parks. Sweden has introduces a tradable green certificate system, whereas Finland has fiscal incentive schemes for new renewable energy. Norway has recently changed from a fiscal incentive schemes to a feed-in system with price premiums.

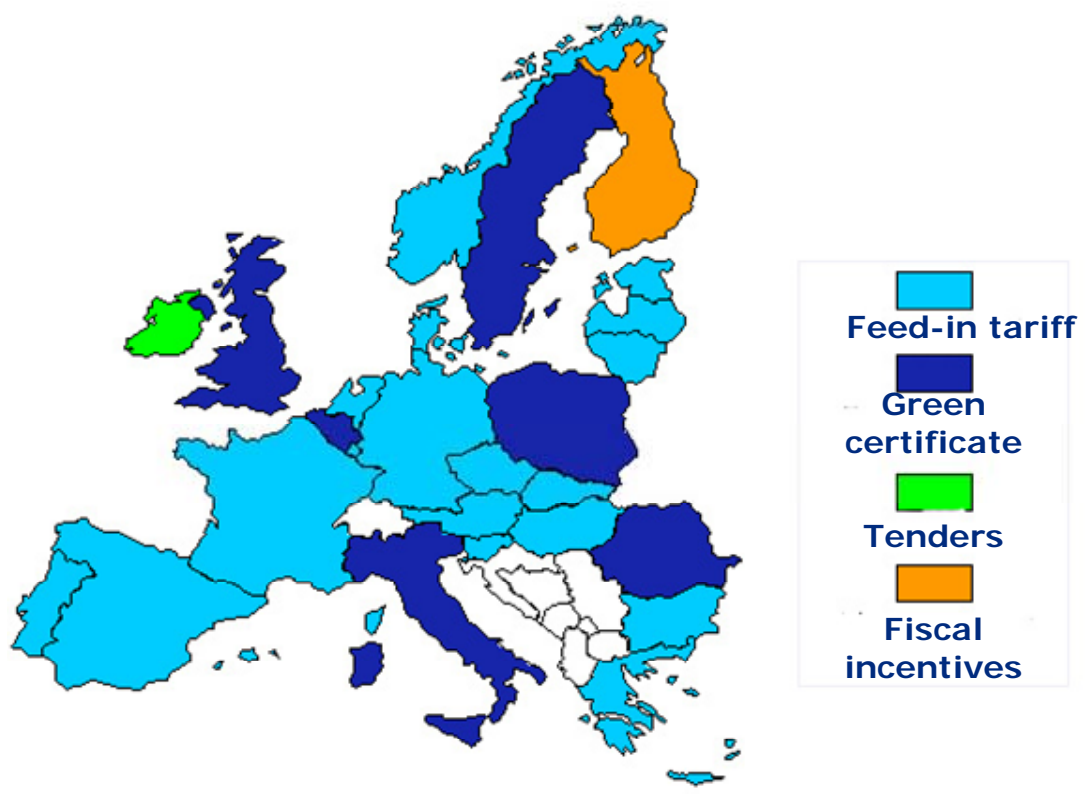

Figure 8: Main support scheme for renewable energy in the EU and Norway.

Source: EU SEC (2004)547 + update.

As mentioned above, discussions within the EU are currently on-going about the need for more harmonised and transparent support systems (EU COM (2006)848 final). However, so far a solution has not been presented.

Some countries have discussed making bi-national support systems (e.g. Sweden and Norway with green certificates) or even regional clusters. However, none of the discussed solutions have yet been implemented. 


\section{The different support schemes}

\section{Feed-in tariff}

In a feed-in system the renewable energy producers receive a regulated subsidy per kWh electricity feet in to the grid. There are two general ways of designing a feed-in system.

- Fixed Feed-In is a regulated subsidy that is often given together with priority access to the network.

- Price premium is given as a regulated premium on top of the market price for electricity.

Fixed feed-in has been very successful in Germany to promote wind power. Price premium is currently used in Denmark.

Both systems can have different regulated tariffs or premiums during the day or week according to a general load profile.

The advantage of fixed feed-in is that the producers know the settling price. The disadvantage is that the producers do not react to market signals which are given by the market price for electricity and which reflect load and demand levels.

The advantage of regulated price premiums is that producers get market signals through the settling price. This gives incentives for producers to being flexible with the supply since they can adjust their production in order to optimise their profit. The reaction to market signals, may also improve the stability of the network. The disadvantage of price premiums is that producers do not know the exact settling price. Producers with intermittent production (e.g. small-scale wind turbines) do not benefit or contribute to the flexibility of the supply side.

\section{Green certificates}

Certificate systems works in many ways like a price premium. However, instead of regulating the level of the subsidy, the demand is regulated through a fixed quota. The certificate price is determined at semi-market conditions with supply competition. The Swedish Elcertifikat system is a good example of a green certificate system.

The advantage of certificate systems is that the market price for certificates together with the power price level reflects the marginal cost for renewables. Like for price premiums the short-term market signals from the power market is reflected in the settling price. The price level of certificates gives investment signals - a high certificate price indicates that actual renewable energy deployment is low compared with the regulated quota (demand) and vice versa. The disadvantage of certificate systems is that producers do not know the exact settling price.

In both feed-in and certificate systems, supply competition for the best locations ensures efficient deployment. The certificates or feed-in tariffs can be either technology neutral (common tariffs / certificates) or technology or area specific (different levels).

The subsidy level (tariff) is known in the feed-in system, but the deployment amount is uncertain. In the certificate system, the deployment amount (quota) is known, but the subsidy level (certificate price) is uncertain. 


\section{Tenders}

Tenders are auctions where potential producers submit bids for constructing and running specific renewable energy projects. Tenders are being used in Denmark for off-shore wind parks.

The design of the tenders can vary from price premiums, fixed tariffs to investment subsidies. Tenders are useful for ensuring a planed deployment at low cost due to supply competition and the fact that the lowest bids win the tenders.

Tenders are especially fitted for large projects with political determined locations, e.g. large wind parks and hydro power.

\section{Denmark}

Denmark has been very successful in promoting the deployment of small scale renewable energy and CHP ('prioritised production'). In fact, Denmark was the first Nordic country to introduce support schemes for renewable energy sources. The main instruments that have been used are feed-in systems, political obligations, investment subsidies and tax refunds.

The political support to renewable energy has been established though different energy plans. As early as in the 1990 "Energy Plan 2000", the Danish Government proposed to increase the use of renewable energy sources by $12-14 \%$ by 2005 compared to the level in 1988. To reach this goal, "Udviklingsprogrammet for vedvarende energi (UVE)" was introduced. UVE subsidised renewable energy projects by a maximum amount of DKK 1 million. $^{7}$ Subsidies were given to

- Solar heat ( with a maximum subsidy $30 \%$ )

- Heat pumps (with a maximum subsidy $15 \%$ )

- Biofuel (with a maximum subsidy $30 \%$ )

- Biogas (with a maximum subsidy $30 \%$ )

This program, with the exception of a few later projects, was terminated in $2004 .^{8}$

The support to renewable energy sources was further strengthened by the 1993 "Biomass agreement". ${ }^{9}$ According to this agreement subsidies were given to

\footnotetext{
${ }^{7}$ http://www.ens.dk/graphics/Publikationer/Forsyning/Evaluering_af_UVE/UVE-standard1.pdf ${ }^{8}$ http://search.ens.dk/cgi-

bin/MsmGo.exe?grab_id=159\&page_id=65792\&query=udviklingsprogrammet+for+vedvarende+ene rgi\&hiword=energi+for+udviklingsprogrammet+vedvarende

${ }^{9}$ http://www.ens.dk/graphics/Energipolitik/dansk_energipolitik/politiske_aftaler/biomasseaftale_ 1993.pdf
} 
- Existing decentralised CHP plants (DKK 10 øre/kWh)

- New CHP decentralised plants (DKK 10 øre/kWh + DKK 17 øre/kWh)

- Centralised CHP plants (A price supplement that together with the market price gives a maximum income at DKK 40 øre/kWh in a 10 year period) ${ }^{10}$

The biomass agreement aimed to increase the use of straw to 1,2 tonnes and the use of wood chips to 0,2 tonnes by 2000. In 1997 the biomass agreement was adapted to increase the flexibility between the use of straw and wood chips. ${ }^{11}$

The Biomass agreement meant that Danish use of biomass resources for energy is at present found mainly within the electricity sector (mostly for CHP). However, new biofuel targets from the EU means that biomass resources will also be used in the transport sector in the future.

In 1996 the Danish Government proposed a new energy action plan, "Energy 21" to further reduce the $\mathrm{CO}_{2}$ emissions from energy sources by sharply increasing the energy production from renewable energy sources. ${ }^{12}$

Since 1993 a feed-in tariff system existed in Denmark, where utilities were obliged to pay wind turbine owners up to $85 \%$ of the electricity price for household consumers.

In 1999 the Danish Government proposed a renewable electricity certificate (VE-bevis) system with a $20 \%$ purchase obligation for all consumers. ${ }^{13}$ The green certificate market was supposed to replace the existing feed-in system from January 2003. However, the introduction of such a green certificate system has been postponed indefinitely due to concerns from the renewable energy sector about the market for green certificates, especially in the European context.

An intermediate scheme was designed for the period until green certificates could be introduced. Until then, there is a premium of 10 øre/kWh instead of the green certificate. The support is now generally lower than in previous policy regimes, in line with the technological development and cost reduction.

From 2004, subsidies to renewable energy sources, except wind power, are given to ${ }^{14}$

- Existing plants, with a maximum limit of market price + subsidy of DKK 60 øre/kWh during 20 years from grid connection, or at least in 15 years

\footnotetext{
${ }^{10} \mathrm{http://www.ens.dk/sw15282.asp}$

${ }^{11}$ http://www.ens.dk/sw13380.asp

${ }^{12}$ http://www.ens.dk/graphics/Publikationer/Energiforskning_UK/VE_Brochure_web.pdf

${ }^{13} \mathrm{http}: / / \mathrm{www} . \mathrm{ens} . \mathrm{dk} / \mathrm{sw13373.asp}$

${ }^{14} \underline{\mathrm{http}: / / \mathrm{www} . \mathrm{ens} . \mathrm{dk} / \mathrm{sw} 15282 . \mathrm{asp}}$
} 
- New plants, with a maximum limit of market price + subsidy at DKK 60 øre/kWh during 10 years and then a maximum of DKK 40 øre/kWh during 10 years.

Subsidies to wind power are given to ${ }^{15}$

- Wind turbines bought before 1999 get a subsidy that together with the market price will ensure a tariff of 60 øre/kWh until full load hours are used up and subsequently 43 øre/kWh until the turbine is 10 years old. Full load hour allowance is 25,000 hours for turbines of $200 \mathrm{~kW}$ or less, 15,000 hours for turbines of 201-599 kW and 12,000 hours for turbines of $600 \mathrm{~kW}$ and over. When the turbine is over 10 years old and its full load allowance is used up, the owner is responsible for sale of production on the electricity market and related costs. A premium of $10 ø r e / k W h$ until the turbine is 20 years old is available. The premium is reduced from 10 to $0 ø r e / \mathrm{kWh}$ as the market price increases from 26 to 36 øre/kWh. There is also an allowance of $2.3 ø \mathrm{re} / \mathrm{kWh}$ for offset costs etc.

- Wind turbines connected to the grid 2000-2002 get at subsidy that together with the market price will ensure a tariff of 43 øre $/ \mathrm{kWh}$ for 22,000 full load hours for turbines on land and 10 years for offshore turbines. Once full load hours are used up, turbine owners are responsible for the sale of production on the electricity market and for related costs. A premium of $10 ø \mathrm{re} / \mathrm{kWh}$ until the turbine is 20 years old is available. The premium is reduced from 10 to $0 ø r e / \mathrm{kWh}$ as the market price increases from 26 to 36 øre/kWh. There is also an allowance of 2.3 øre $/ \mathrm{kWh}$ for offset costs etc

- Wind turbines connected to the grid 2003-2004 get a premium of $10 ø r e / k W h$ until the turbine is 20 years old. The premium is reduced from 10 to 0 øre/kWh as the market price increases from 26 to 36 øre/kWh. There is also an allowance of 2.3 øre/kWh for offset costs etc

- Wind turbines on-shore connected to the grid from 2005 receives a price premium of DKK 10 øre $/ \mathrm{kWh}$ in addition to the power price (for 20 years). There is also an allowance of 2.3 øre/kWh for offset costs etc.

- The 2 new (2009 and 2010) off-shores wind parks receives after tendering rounds a subsidy that combined with the market price comprises 51.8 and 49.9 øre/kWh respectively. The subsidy is payable for 50,000 full load hours.

\footnotetext{
${ }^{15}$ http://ens.dk/sw13754
} 


\section{Finland}

In Finland, the first subsidy scheme for renewable energy sources (and peat) was introduced in 1997, covering small installations. The purpose of the subsidy was to increase the competitiveness of small installations. This support scheme was later expanded to include all renewable energy sources, except hydropower. In 2003, it included wind power, small hydropower (less than $1 \mathrm{MW}$ ) and electricity produced from wood fuels, recycled fuels and biogas. Also industrial produced heat from chemical processes and electricity from metallurgical waste gas processes receive subsidies. There are now three levels of subsidy, depending on the energy source. ${ }^{16}$

- €c 0.25/kWh: recycled fuels

- €c $0.69 / \mathrm{kWh}$ : subsidies to wind power and forest chips

- €c 0.42/kWh: others

\section{Iceland}

Hydropower and geothermal energy are the main renewable energy sources in Iceland. These technologies have gained investment support or have been deployed by state or county owned companies.

There is no support to electricity generation or heat production from these plants.

\section{Norway}

The present goal for Norway is to achieve 12 TWh of energy conservation and energy production by new renewable energy within 2010. Of this, at least 4 TWh must be district heating based on new renewable energy sources, waste heat or heat pumps, and at least 3 TWh wind power.

Hydropower has been utilised widely in Norway. State- or county owned companies have build most of the (large scale) plants before the deregulation of the market in the early 1990ies. Most of the large-scale hydro power in Norway was built before the deregulation of the market, and new large-scale hydro is not eligible under current renewables support schemes. A large portion of the remaining large-scale hydro resources is not available for exploitation; they are protected by nature conservation regulations.

During the 1990ies support for other renewable energy sources was given in the form of investments subsidies. Special simplified concession rules apply to small-scale hydropower (less than $10 \mathrm{MW}$ ).

\footnotetext{
${ }^{16}$ http://www.ktm.fi/index.phtml?l=sv\&s=195
} 
Wind energy was introduced as a renewable energy alternative in 1990 (NVE, 2005) ${ }^{17}$. The first projects were pilot projects, and the process to licence the first large projects commenced in 1997/98. By the end of 2005, wind power capacity had grown to $280 \mathrm{MW}$.

In 2002, Enova SF was established, a government agency that administers support to energy efficiency and renewable energy projects. Enova also administers the support scheme to promote infrastructure for domestic supply of natural gas.

In early 2000, the government planned to establish a green certificate market joint with Sweden. However, the negotiations were terminated in the beginning of 2006, just before the system was to be launched. In autumn 2006, a new support scheme for renewable electricity based on feed-in tariffs was announced; this scheme is to come into force from January 1, 2008. The feed-in tariffs are differentiated between technologies:

- Bio fuelled CHP: 10 øre/kWh

- Wind power: 8 øre/kWh

- Small-scale hydro: 4 øre/kWh

\section{Sweden}

Prior to 1991 there was no support for renewables in Sweden. In 1991, several support schemes for renewable energy were introduced, including wind power, bio-fuelled power and solar heat. The support schemes were mainly designed as investment subsidies, e.g. 4,000 SEK/kW for bio fuelled power and 15\% of total investment costs for wind power. In July 1994 an environmental bonus was added to the wind power subsidy. The bonus was designed as a production subsidy (per kWh) and it equalled the electricity consumption tax.

In May 2003 a green certificate system was introduced. This scheme includes all new renewable electricity generation. Demand for electricity certificates has become mandatory through a quota obligation, i.e. a certain share of the electricity consumption (excluding industry) has to be supplied from "certified" renewable energy generation. The quota obligation will be gradually increased to achieve the Swedish target of realizing an additional 10 TWh of electricity from renewable energy sources in 2010 compared to the level in 2002, and 17 TWh in 2016. The environmental bonus for wind power has not been removed, but will be gradually phased out within 2010.

\footnotetext{
${ }^{17}$ Vindkraft I Norge - status januar 2005.
} 


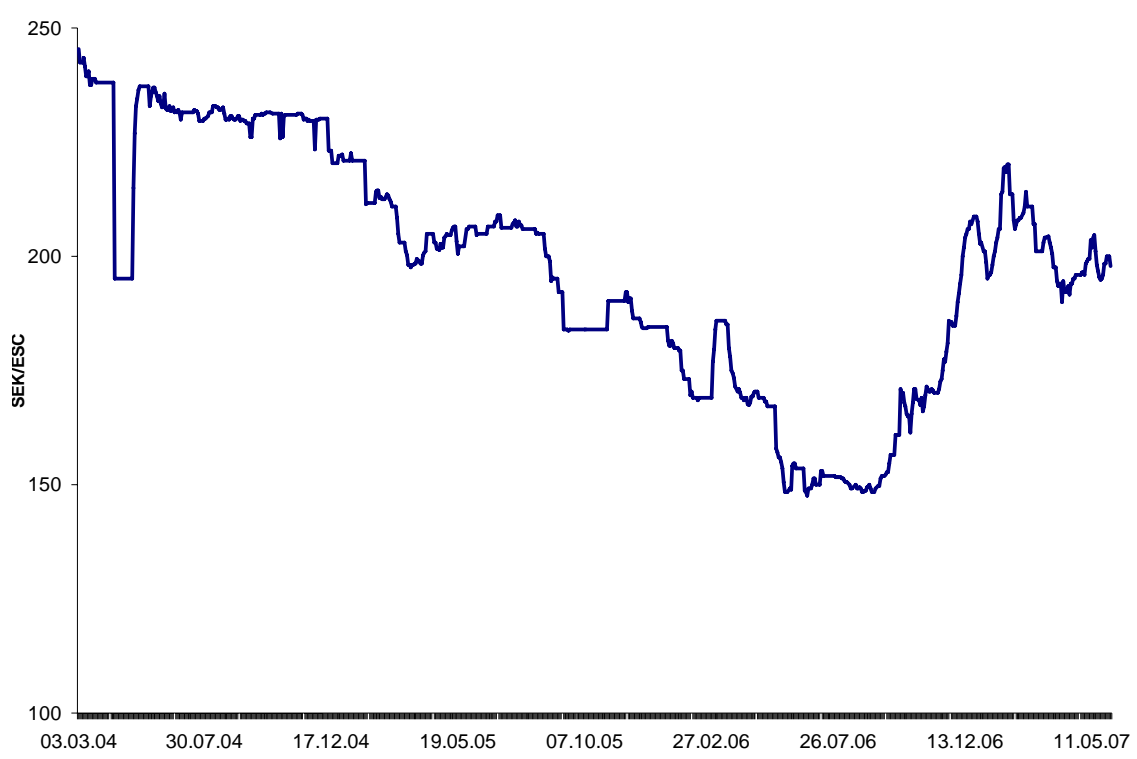

Figure 9: Price development of green electricity certificates in Sweden.

Source: Nordpool.no

Compared to the electricity spot price the electricity certificate price has been very stable and has only showed small fluctuation (Figure 9).

The electricity certificate scheme has led to a significant increase in support for electricity based on biofuels.

\subsection{Support to renewable energy sources through $\mathrm{CO}_{2}$ pricing}

All Nordel countries introduced $\mathrm{CO}_{2}$ pricing in the beginning of the 1990ies in order to reduce $\mathrm{CO}_{2}$ emissions and increase the use of renewable energy sources. The $\mathrm{CO}_{2}$ taxes in the Nordel countries are levied on fuel's carbon content. The $\mathrm{CO}_{2}$ taxes in Denmark, Finland, Norway and Sweden are presented in detail in the report "The impact of renewables and energy efficiency on $\mathrm{CO}_{2}$ emissions (project no. 52 060)".

A pan European emission trading scheme (the ETS system) was introduced in 2005 implying common $\mathrm{CO}_{2}$ prices in Sweden, Denmark and Finland.

In 2005-2007, a domestic emission quota system similar to the EU ETS was introduced in Norway. Industries that are included in the EU ETS and that had been exempted from the $\mathrm{CO}_{2}$ tax became subject to the quota system. From 2008, the Norwegian quota system will supposedly be linked to EU ETS, implying that similar industries will be included in the system. For these industries, the quota system will replace the present $\mathrm{CO}_{2}$ tax.. However, there is an exception for the petroleum sector which will be included in the ETS but keep the $\mathrm{CO}_{2}$ tax as well. 



\section{Consumer Prices and Energy Levies and Taxes}

\subsection{Energy Consumption in the Nordic Countries}

The Nordic countries have some of the highest energy taxes within the EU/EEA area. In spite of this energy consumption per capita is in general higher than in the rest of the EU. Only Denmark has an energy intensity that is close to the EU average (Figure 10). There is a similar high energy consumption compared to the GDP (the energy intensity).

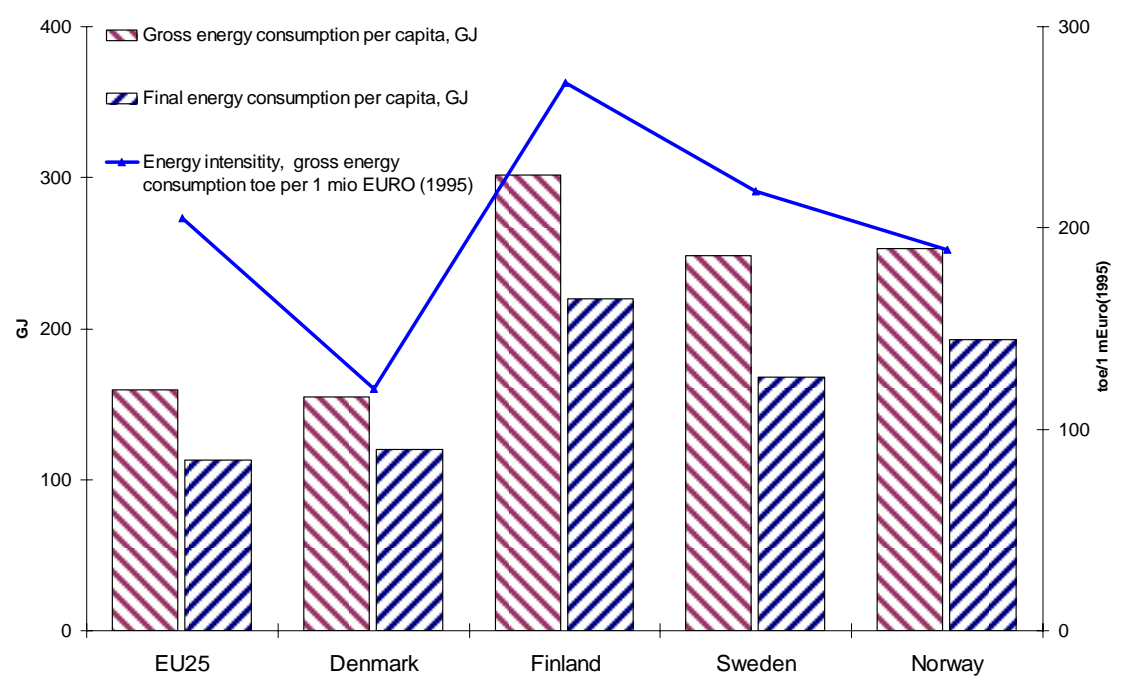

Figure 10: Energy consumption per capita and energy intensity in the Nordic countries (excl. Iceland). Source: EuroStat and the Danish energy agency.

In this chapter we will look further into the combination of the energy taxes in the Nordic countries. We will have a closer look at which consumer groups have high energy consumption.

The total gross energy consumption in the Nordic countries is very different when we compare sector by sector (Figure 11). This is shown in the figure below. The energy consumption of the primary industries is relatively low in most Nordic countries except for Norway. The industrial sectors in Norway, Sweden and Finland account for a relatively large part of consumption (from 27-45\%) while in Denmark it is down to $14 \%$ due to a very small energy-intensive industry. 


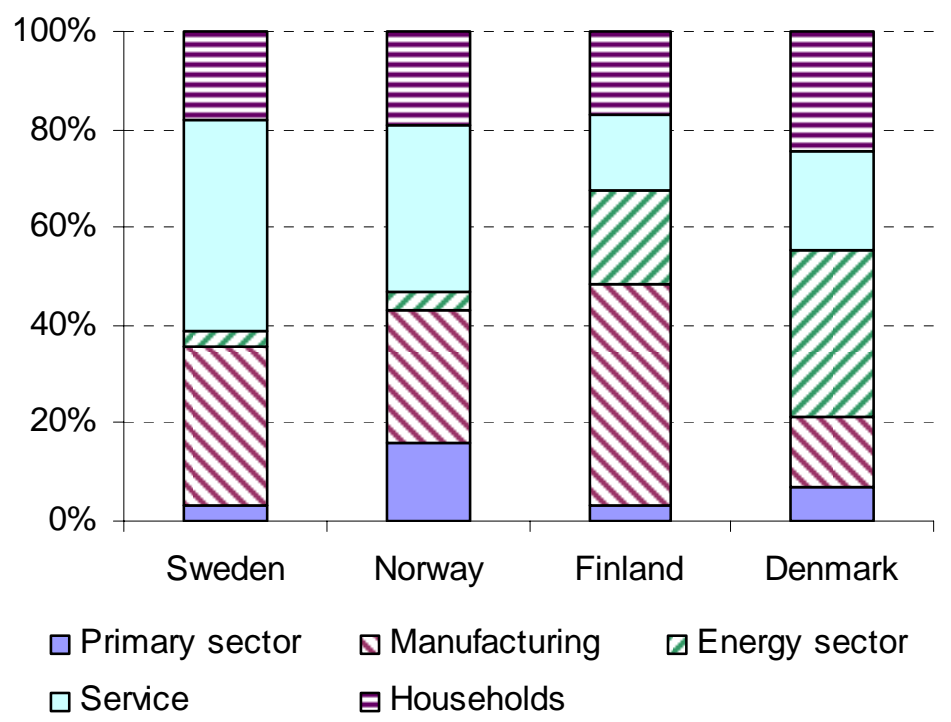

Figure 11: Gross energy consumption per sector (in \%). Source EuroStat 1999.

The gross energy consumption of the energy industry is relatively high in Denmark and Finland compared to the other sectors in these countries. The difference between gross energy consumption and net energy consumption is the energy losses that happen before the energy reaches the consumer.

A large part of energy losses is associated with the energy sectors' own energy consumption (Figure 12). On the EU level the energy sectors' energy consumption is generally a significant part of the total gross consumption. This is mainly due to energy losses in the conversion to electricity, district heating or other types of energy. The energy consumption of the energy sector is very different in the Nordic countries. Sweden and Norway have the lowest losses, which is due to the fuel mix with a great deal of hydropower and nuclear power.

\section{Energy consumption}

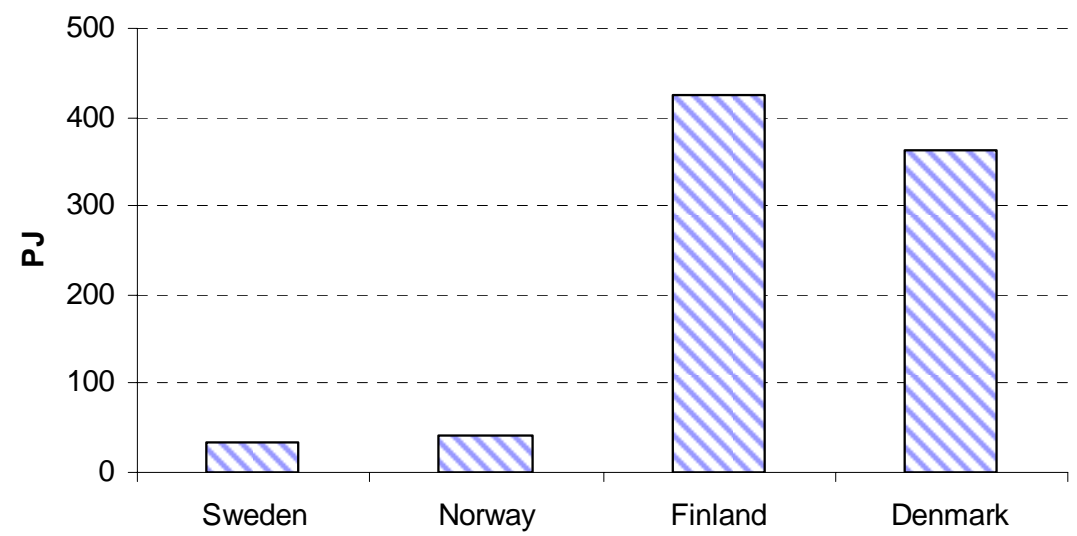

Figure 12: Energy use in the energy sector. Source: EuroStat 1999. 
Denmark and Finland have the highest relative energy consumption in the energy sector because the Danish and Finish energy mixes are primarily based on fossil fuels with high conversion losses (see also Figure 7 in the previous chapter).

In the rest of the report we focus on the net energy consumption. The analysis will be limited to the consumption of electricity, district heating, natural gas and fuel oil.

\subsection{Electricity consumption}

Electricity consumption constitutes a very large part of the net energy consumption in the Nordic countries. We have therefore chosen to look somewhat deeper into the electricity consumption compared to the other types of energy.

The electricity consumption per capita in the Nordic countries differs a great deal from country to country (Figure 13). Denmark has through the last decade had relatively low and constant electricity consumption per capita. In spite of the GDP growth, electricity consumption has stayed at a constant level.

Norway has a relatively high level of electricity consumption per capita. This is especially due to the use of electric heating of houses and a relatively large power intensive industry.

During the last 10 years, in al of the Nordic countries there have been efficiency improvements in the use of electricity for space heating. At the same time, however, the use of electrical appliances have increased in the households.

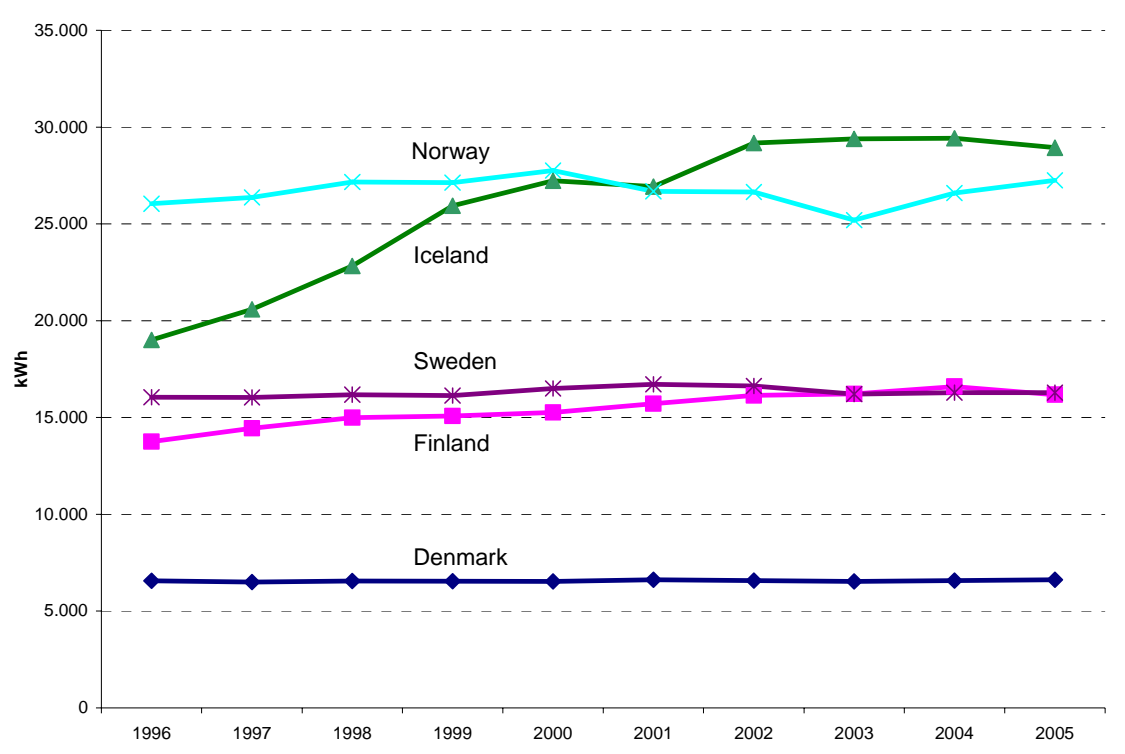

Figure 13: Total electricity consumption per capita in the Nordic countries.

Source: Nordel 2006. 
Electricity consumption per capita in Iceland increased a great deal in the 1990s, but has remained at a constant level since 2002. The increase in consumption was especially due to a growing power-intensive industry aluminium production among other things - and low electricity prices.

The distribution of electricity consumption per sector and country (relative shares) is shown in Figure 14. As mentioned the industry accounts for a large share of electricity consumption in Iceland (76\%).

The service sector in Denmark has a relative large share (33\%) compared to the other countries (10-22\%). This has to be compared with the relatively small electricity consumption per capita in Denmark, the fact that there is almost no power intensive industries in Denmark and that the use of electrical space heating is limited.

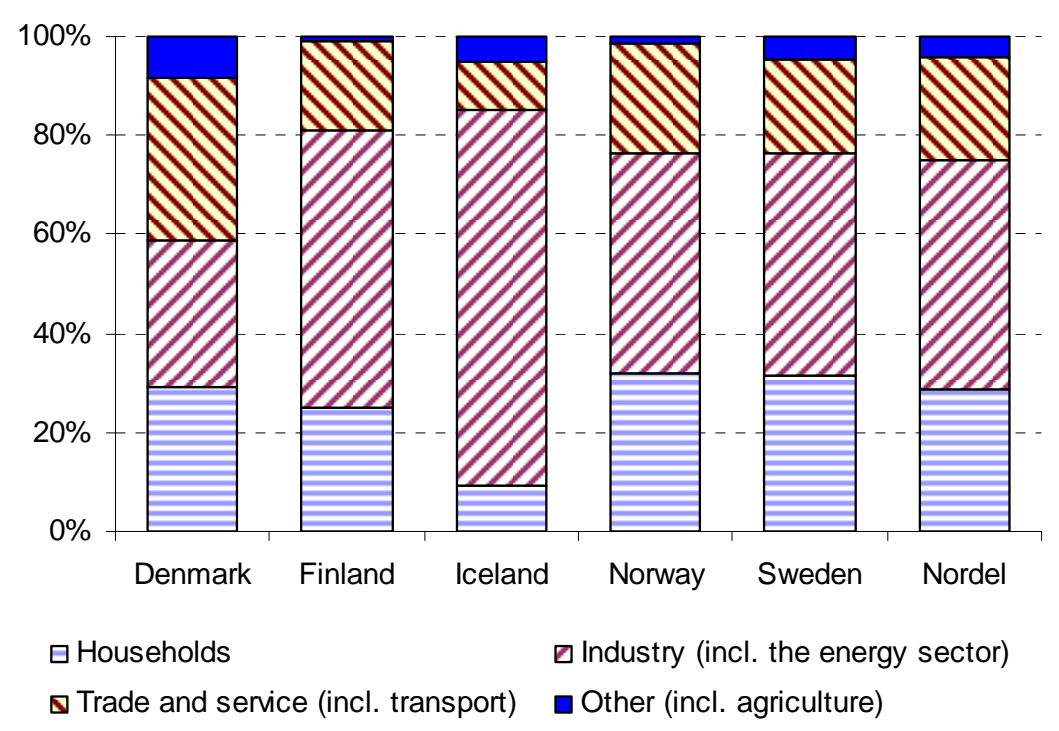

Figure 14: Relative net consumption of electricity in 2005.

Source: Nordel 2006.

For the Nordic countries in total (the Nordel area) the industry accounts for almost half of the electricity consumption and the household and service sectors counts for respectively $29 \%$ and $21 \%$.

\subsection{Space heating in households}

The dominating fuel or technology in household space heating varies substantially between the Nordic countries, from predominantly geothermal in Iceland to electricity in Norway. District heating is widely used in most of the Nordic countries (except Norway). 


\section{Denmark}

Compared to the other Nordic countries Denmark has a completely different mix of space heating installations. The Danish mix of installations has changed a lot during the last two decades. Until the mid 80'ies oil boilers were the dominating heat installation in Danish households. Now, especially district heating and natural gas boilers have substituted oil (see figure below). Biomass, electric heating and other alternative space heating installations only have a minor share.

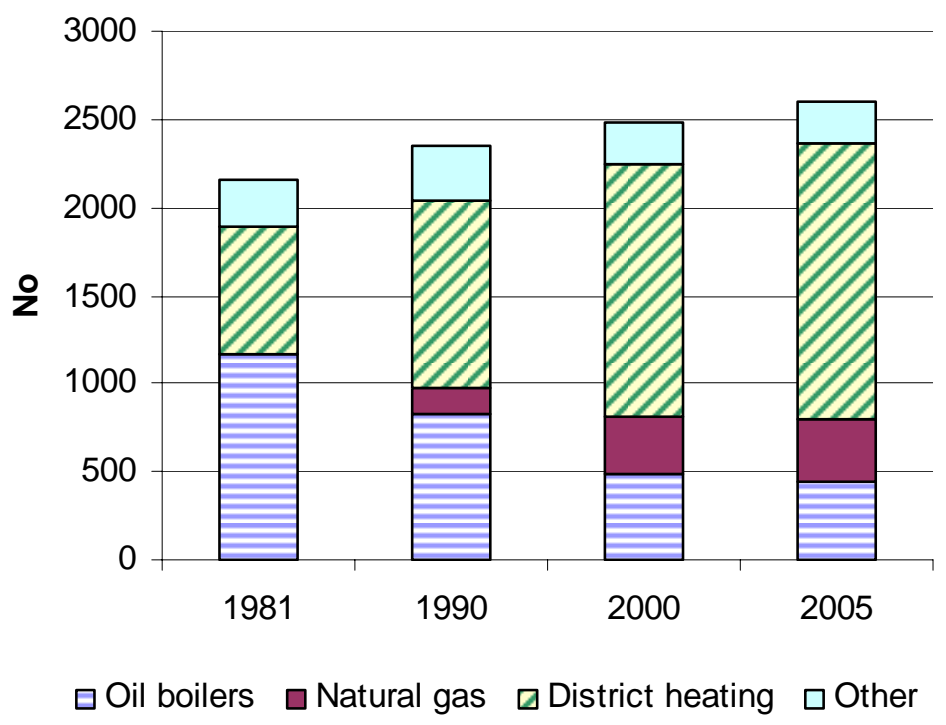

Figure 15: Number of comfort heat installations in households in Denmark.

Source: Energistatistikken, Energistyrelsen 2006.

The progress in use of natural and district heating is mainly due to central planning in the 80ies. The building of the natural gas and district heating networks required massive investments and in order to ensure that a sufficient amount of households would be connected to the grids, the planning was made central for Denmark. The natural gas and district heating grids were planned in such a way that they did not overlap and at the same time covered densely populated areas, i.e. most households should have access to natural gas or district heating, but no household would have access to both (no possibility for substitutions between the two energies).

Connection to the grids was made mandatory in the large supply areas with a transition period of 8-10 years for existing installations - allowing households time to face out their existing boilers.

Since 1988, electric heating as primary space heating energy has not been allowed in new houses with access to public energy supply (natural gas or district heating), and from 1994 existing houses were no longer allowed to use electric heating. 
The central planning of the public supply of energy for space heating in households has the effect that electricity is mainly used for electrical appliances, and district heating, natural gas and oil are used for space heating. In other words, there are de facto no substitution opportunities between electricity and the other space heating sources (district heating, natural gas and oil) in the majority of Danish households.

Outside the large cities, where there is no public supply of district heating and natural gas, oil boilers are still the main space heating installations in households. Use of firewood, wood pellets and other alternative installations only count for a small share of the total consumption and are often installed as supplement to the main installations.

The replacement of fuel oil burners with more energy- and environment efficient installations (district heating and natural gas) has resulted in a significant reduction in the environmental impact of the Danish households.

\section{Iceland}

Space heating in household is mainly from geothermal power in Iceland.. The share of geothermal energy in space heating in Iceland is around $87 \%$. However, oil and electricity is also used. District heating is commonly used in Iceland.

\section{Finland}

In the Finish household and service sectors, the use of oil has steadily declined since the beginning of the 1990ies while the use of district heating and electricity has increased, leading to an overall increase in final energy use. The estimated use of bio fuels, almost exclusively fire wood, has remained stable throughout the period.

Finland has a lot of combined heat and power plants (CHP), which is applied widely for the heating of communities and use of waste fuels from industrial processes. District heating warms almost half of the buildings in Finland, and 3/4 of district heat is produced by CHP.

\section{Norway}

Due to low electricity prices for households (in the past) electric space heating is one of the major consumers of electricity in households in Norway 
Sweden

Also in Sweden, electric space heating is one of the major consumers of electricity in households. However, instead of only having electric panels, heat pumps are also being installed, and during the last decade the energy efficiency of the new heat pumps have improved a lot. Sweden has installed more than 185.000 geothermal heat pumps in private households.

In Sweden, district heating has been very successful in achieving a considerable share of the heat market since the introduction in 1948. In the last decade there has been a tremendous expansion of district heating. Today Sweden (together with Denmark) is one of the leading district heating countries in the Nordic countries with annual heat deliveries totalling about 40 TWh. On average, every Swede consumes 4,500 kWh of heat from district heating systems per year.

Waste-to-energy plants serving district heating systems are common in Swedish cities.

\subsection{Consumer Prices}

Indexes for consumer prices are often made differently for each country. In order to compare consumer prices a common index definition is needed. Fortunately, in addition to their national consumer price indices, the Member States of the European Union also produce the Harmonised Index of Consumer Prices (HIPC), from which Eurostat, the Statistical Office of the European Communities, calculates the European index of consumer prices

HICPs are calculated in each member state of the European Union for the purposes of European comparisons of consumer price inflation as required by the Maastricht Treaty. From January 1999, it has been used by the European Central Bank as the measure for its definition of price stability across the Euro area.

The HIPC for electricity is a measure of the electricity price that households face. The HIPC data for electricity for each country can be obtained from Eurostat and in the Figure 16 we have adjusted these series for inflation by using the HIPC for all goods in each country. 


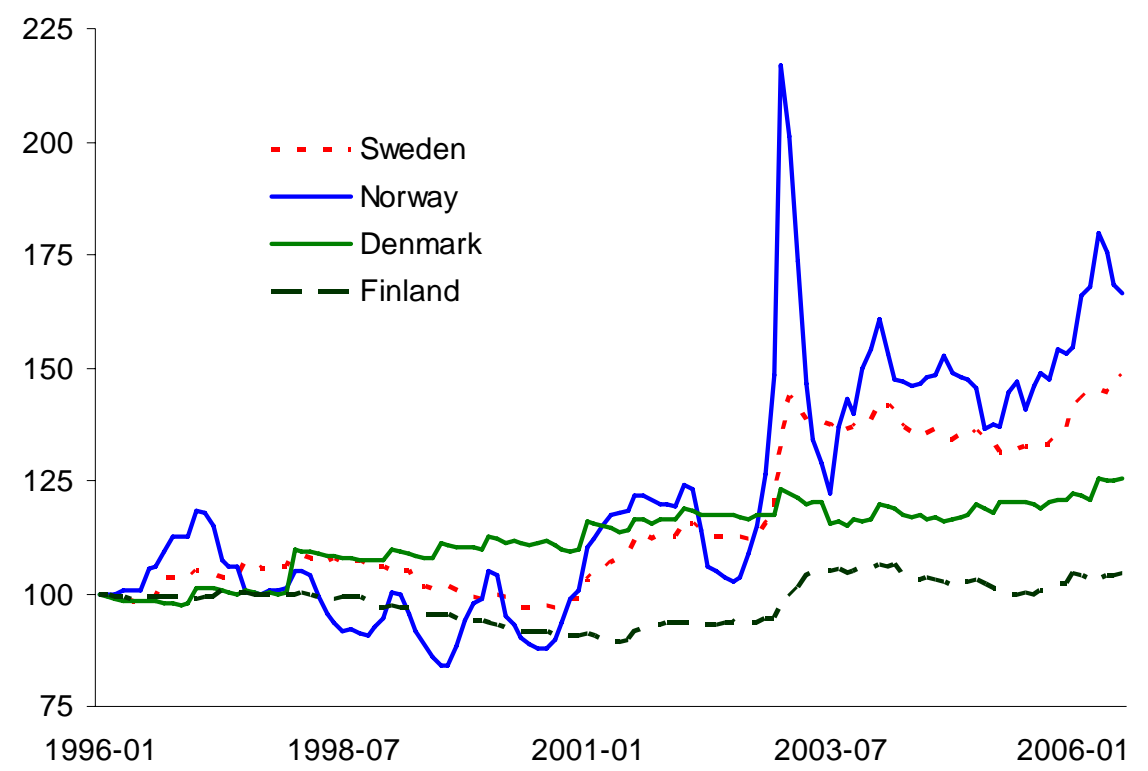

Figure 16: The development of the index for HIPC for electricity over time.

Source: Eurostat.

All the HIPC indexes for electricity show a positive trend starting around 2002. Measured over the entire period from January 1996 to July 2006, the electricity price increases in all of the Nordic countries. However, the magnitude of the price increase differs substantially between the four countries. In total, the electricity price in Norway increases by almost $70 \%$ over the period, whereas the corresponding price increase amounts to less than 5\% in Finland. In addition, the volatility of the electricity price index seems to be considerably larger for Norway than for the other Nordic countries.

The small variations in the electricity price index of the other countries, especially Finland, could possibly make it difficult to find a relationship between electricity price and consumption. We return to this problem in Chapter 3 where we apply an econometrical model to analyse the relationship between prices and consumption.

\section{Energy taxes}

Energy taxes and levies are widely used in the Nordic countries to influence energy use, emission levels and as part of the government's tax income portfolios. It is not always the consumer group that consumes the most that has the largest energy tax burden. Eurostat (Eurostat, Energy Taxes in the Nordic Countries, 2003) found that the energy use and the burden of the energy tax are not equally distributed. In general the industries' share of the tax burden is lower than their share of energy use, whereas the households pay more than their relative energy use. Figure 
17 summarises the relative shares of consumption and energy taxes per consumer group in Sweden, Norway, Finland and Denmark.

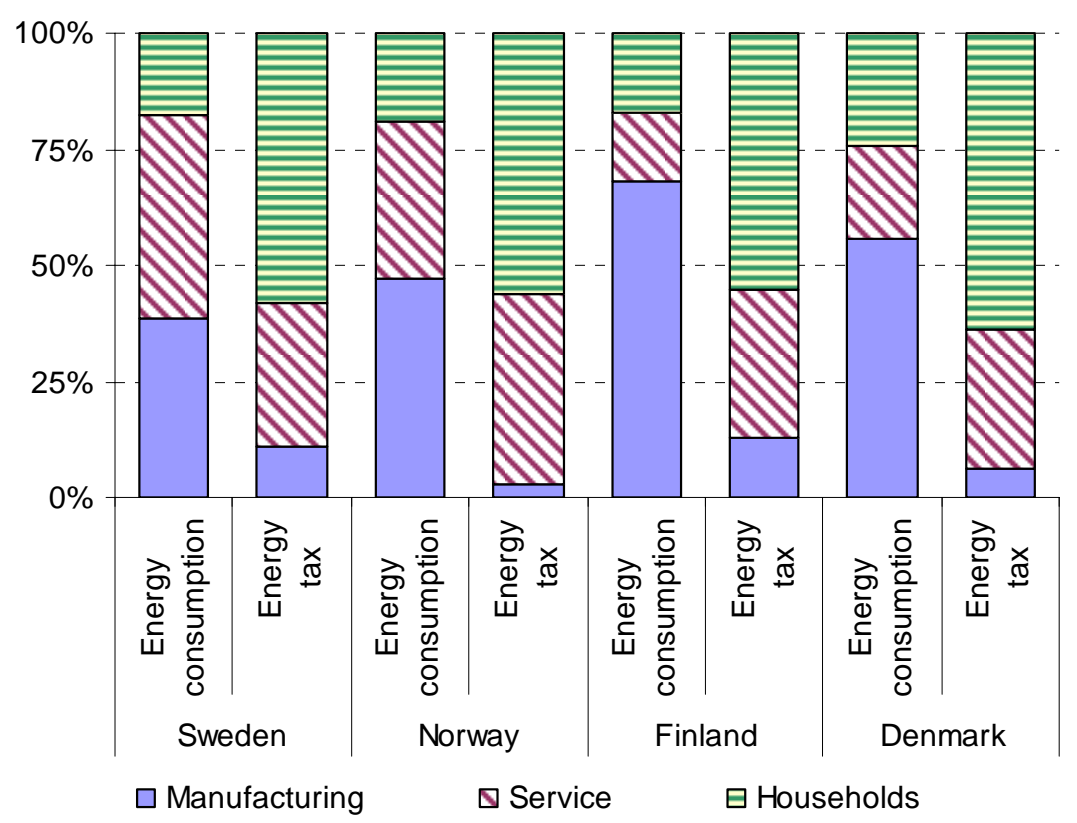

Figure 17: Relative energy use and energy taxes paid, 1999.

Source: Eurostat 2003.

On an EU level, a recent Directive has added gas and electricity to the Community list of energy products subject to a uniform indirect tax framework. This Directive forced many EU Member States to adapt their indirect tax systems per 1 January 2004 (or 1 May 2004 for the Accession countries). The energy tax systems in Denmark, Sweden and Finland have been adjusted in accordance to this.

\section{Denmark}

The oil and natural gas prices in Denmark have been linked - when the oil price went up, the natural gas price went up (Figure 18).

As mentioned above, especially households in Denmark use natural gas and district heating. In Denmark the price for district heating depends on the supply areas. However, the price for district heating is regulated and the price development follows the development in the other energy prices. 


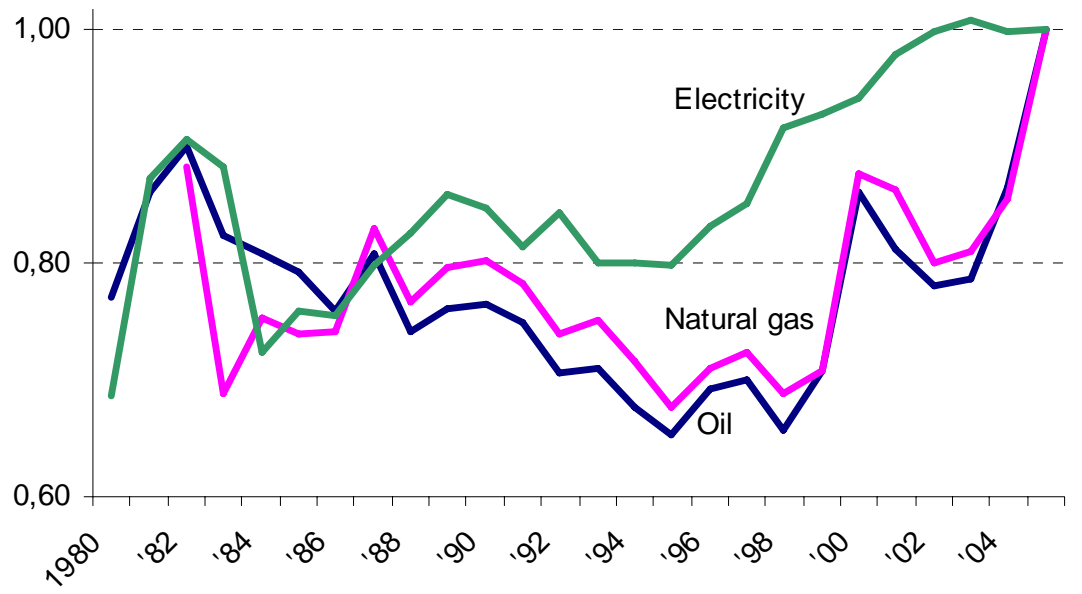

Figure 18: Relative price development for energy to households in Denmark. Fixed 2005 prices with the 2005-price indexed to 1.

Source: Energistyrelsen.

The electricity price for households has increased during the last decade. This is mainly due to increased electricity consumption taxes. The energy tax that applies to the use of coal, oil, gas and electricity was introduced in the 1970ies. The tax rate depends on the energy content of the fuel. The current rate on coal, oil and gas corresponds to DKK 51.9/GJ. For oil products used in engines the tax rate is higher.

The share of energy tax for oil and electricity to households is illustrated in Figure 19. The energy tax on electricity to households has increased from 0.33 DKK/kWh in 1990 to $0.666 \mathrm{DKK} / \mathrm{kWh}$ in 2005.

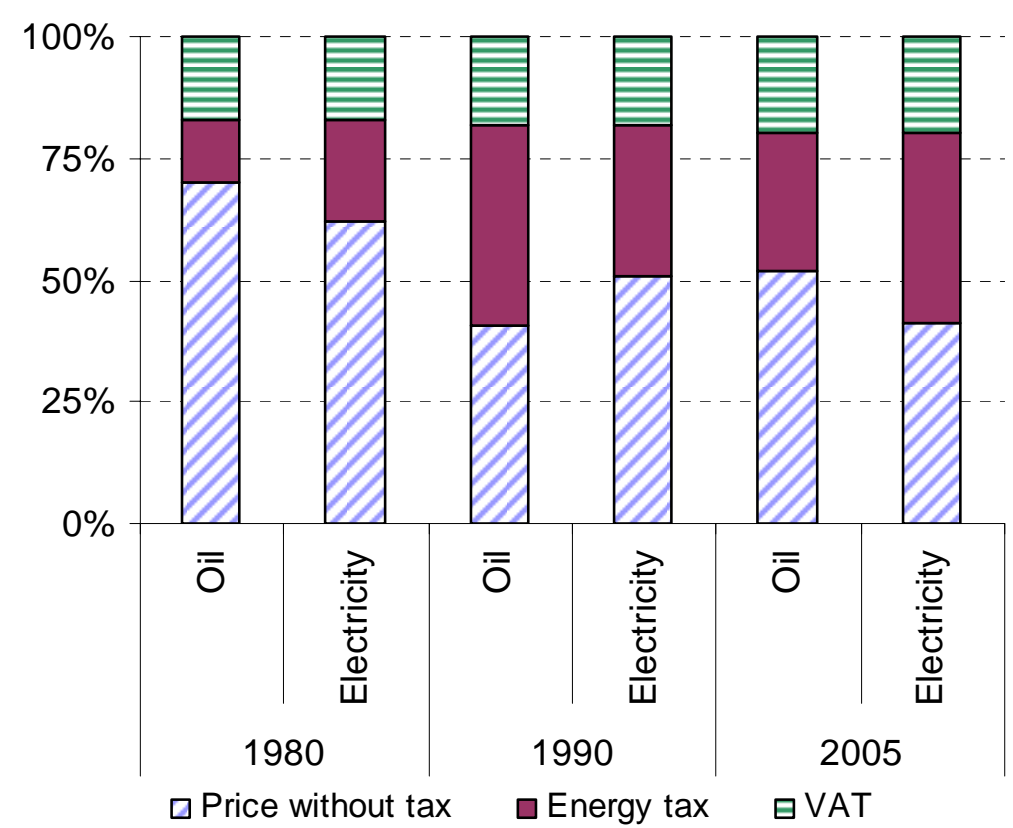

Figure 19: Development in the share of energy taxes in the energy prices for households in Denmark. Without distribution costs.

Source: Energistyrelsen. 
Fuels used for electricity production are exempted from taxation. The level of the energy taxes and levies on electricity consumption differ between households and industries (highest for households). However, the taxes are always flat (66.6 øre/kWh for households). For companies, taxes vary according to purpose. Reduced levels of taxes are allocated to energy intensive end-uses, while electricity for space heating is taxed at a higher rate. The VAT of $25 \%$ is calculated on the total value (including the taxes; see table below), however, for companies VAT is refunded.

Table 3 Typical electricity prices for different consumer groups in Denmark.

\begin{tabular}{|c|c|c|c|c|c|c|}
\hline & \multicolumn{2}{|c|}{$\begin{array}{l}\text { Households } \\
4,000 \mathrm{kWh}\end{array}$} & \multicolumn{2}{|c|}{$\begin{array}{c}\text { Small } \\
\text { companies } \\
100 \mathrm{MWh}\end{array}$} & \multicolumn{2}{|c|}{$\begin{array}{c}\text { Large } \\
\text { companies } \\
50 \mathrm{GWh}\end{array}$} \\
\hline & øre/kWh & $\%$ & øre/kWh & $\%$ & øre/kWh & $\%$ \\
\hline Grid subscription & 14.2 & $8 \%$ & 3.8 & $5 \%$ & 0.1 & $0 \%$ \\
\hline Grid tariff & 33.6 & $19 \%$ & 31.2 & $44 \%$ & 23.8 & $47 \%$ \\
\hline - distribution & 12.6 & $7 \%$ & 10.2 & $14 \%$ & 2.9 & $6 \%$ \\
\hline - regional transmission & 0.6 & $0 \%$ & 0.6 & $1 \%$ & 0.5 & $1 \%$ \\
\hline - PSO & 14.9 & $8 \%$ & 14.9 & $21 \%$ & 14.9 & $30 \%$ \\
\hline $\begin{array}{l}\text { - grid and system } \\
\text { tariff }\end{array}$ & 5.5 & $3 \%$ & 5.5 & $8 \%$ & 5.5 & $11 \%$ \\
\hline Total grid payment & 47.8 & $27 \%$ & 35 & $49 \%$ & 23.9 & $48 \%$ \\
\hline $\begin{array}{l}\text { Net electricity } \\
\text { subscription }\end{array}$ & 2.2 & $1 \%$ & 0.1 & $0 \%$ & 0 & $0 \%$ \\
\hline Net electricity price & 26.2 & $15 \%$ & 26.2 & $37 \%$ & 19.1 & $38 \%$ \\
\hline $\begin{array}{l}\text { Total electricity } \\
\text { price without taxes } \\
\text { and VAT }\end{array}$ & 76.2 & $43 \%$ & 61.3 & $86 \%$ & 43 & $85 \%$ \\
\hline VAT and taxes & 102.3 & $57 \%$ & 9.7 & $14 \%$ & 7.3 & $15 \%$ \\
\hline - CO2 tax & 9 & $5 \%$ & 8.7 & $12 \%$ & 6.3 & $13 \%$ \\
\hline - electricity tax & 53 & $30 \%$ & 0 & $0 \%$ & 0 & $0 \%$ \\
\hline - distribution levy & 4 & $2 \%$ & 1 & $1 \%$ & 1 & $2 \%$ \\
\hline - pow er savings levy & 0.6 & $0 \%$ & 0 & $0 \%$ & 0 & $0 \%$ \\
\hline - VAT & 35.7 & $20 \%$ & 0 & $0 \%$ & 0 & $0 \%$ \\
\hline $\begin{array}{l}\text { Total electricity } \\
\text { price including } \\
\text { taxes and VAT }\end{array}$ & 178.5 & $100 \%$ & 71 & $100 \%$ & 50.3 & $100 \%$ \\
\hline
\end{tabular}

The large share of flat rate energy taxes in the consumer price for households implies that household prices are hardly sensitive to fluctuations in the wholesale electricity price. ${ }^{18}$ The price to industry on the other hand, is much more sensitive to fluctuations in wholesale electricity prices since the energy part of the consumer price is relatively large.

\footnotetext{
${ }^{18}$ see also the econometrical analysis in next chapter.
} 
The energy tax level for households has increased by more than $50 \%$ since 1996 to 2002. It has been constant between 2002-2004 and 20052007 (Figure 20).

Since energy taxes constitute around $1 / 3$ of the final consumer price, and compared with the development of the HIPC for electricity to households described above, it is evident that the increase in the level of energy taxes is passed through in end-user prices.

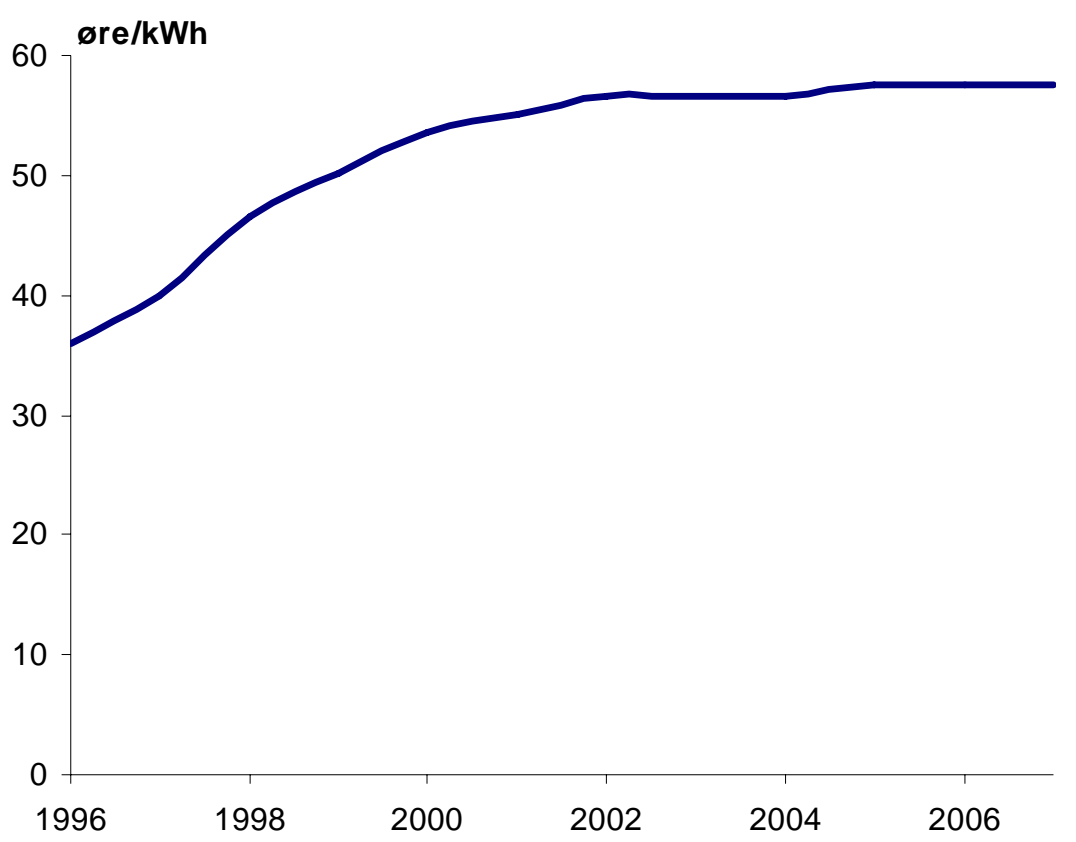

Figure 20: Historical development of the energy taxes (without CO2 tax and VAT) for households in Denmark. Source: www.skat.dk

\section{Iceland}

As mentioned above district heating is commonly used for space heating in Iceland. District heating utilities in Iceland can be divided roughly into two groups: the ones utilising geothermal energy, as are the most common, and the ones using electricity or petroleum fuel to heat water in boilers.

The share of geothermal energy in space heating in Iceland is around $87 \%$. There is a sizeable difference in space heating costs and energy prices depending on the heating utility, or from ISK $0.50-2.80$ per $\mathrm{kWh}$, depending on the utility concerned.

Since 1982, electricity for residential heating has been subsidised by the state and energy enterprises. The purpose of this is to equalise energy costs throughout Iceland; the subsidies are paid to regions which cannot avail themselves of geothermal heating (Figure 21).

On 8 May 2002, an Act on Subsidised Residential heating entered in to force. 


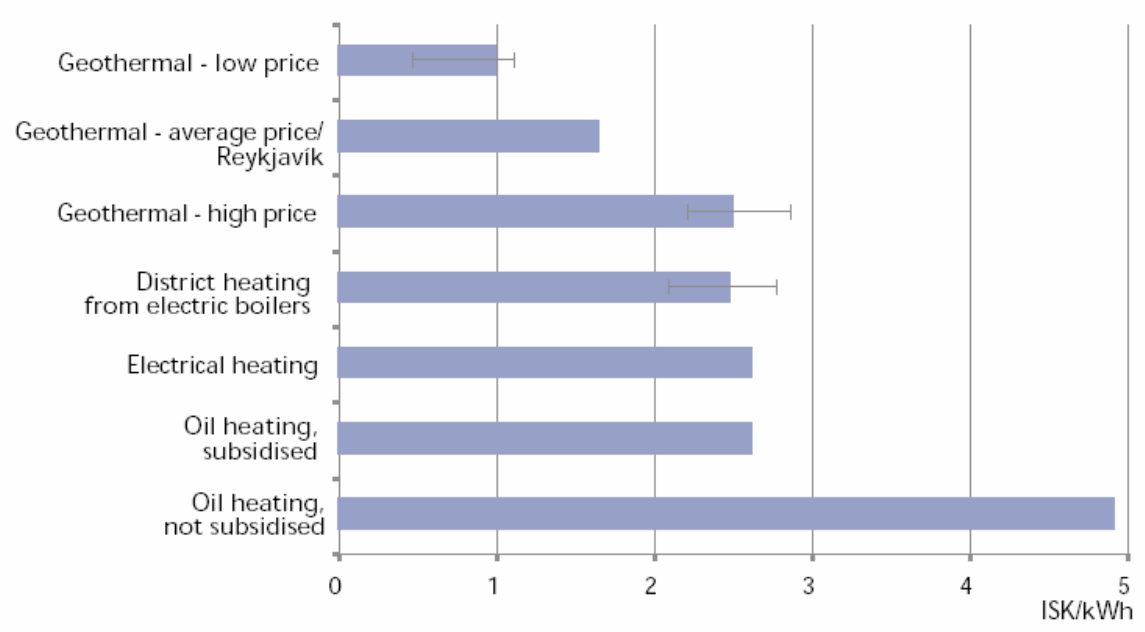

Figure 21: Comparison of energy prices for residential space heating.

Source: Energy in Iceland, National Energy Authority, Iceland, 2004.

The various developments in the price indexes for energy in Iceland is shown in the Figure 22 below.

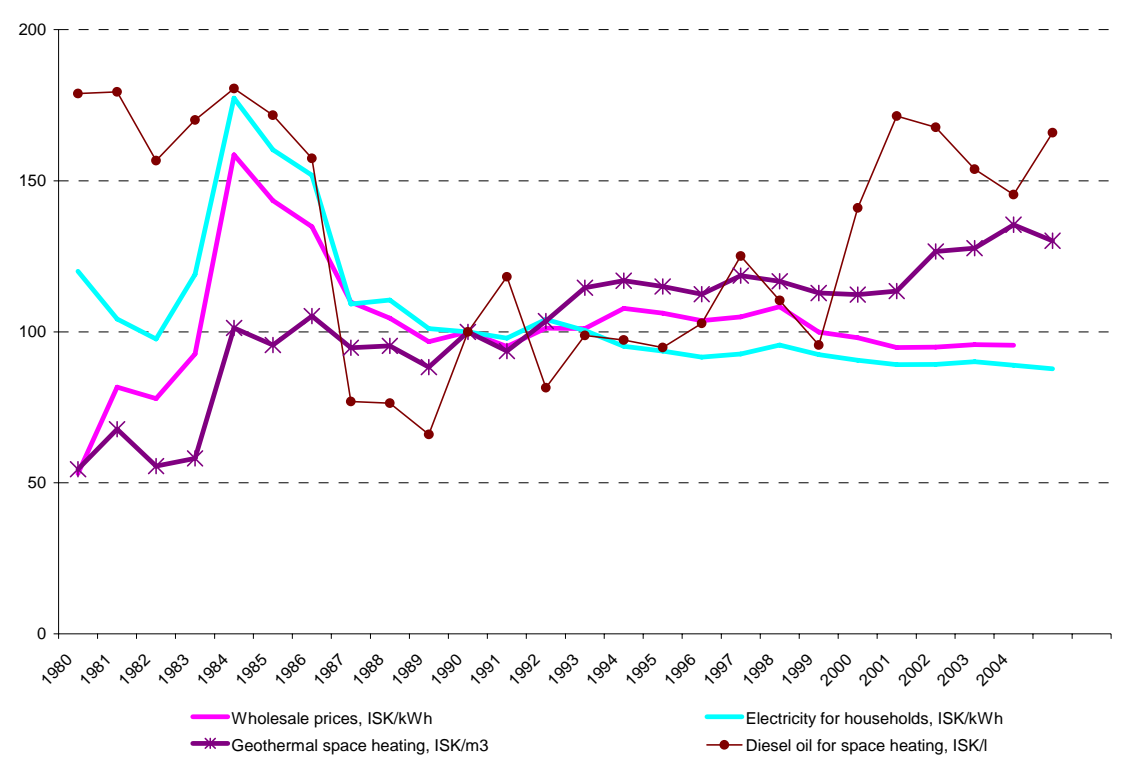

Figure 22: Price indexes of various energy forms 1980-2005 in Iceland. Prices in January each year, Price index deflated by consumer price. Index: $1990=100$.

Source: Statistics Iceland.

\section{Finland}

The energy tax system in Finland consists of fuel taxes on fuels used for transportation and heating, and electricity taxes. The fuel tax is divided into a basic duty and a $\mathrm{CO}_{2}$ tax.

Between 1993 and 1997, there was a tax on electricity production and imports (Figure 23). However, since 1 January 1997 (simultaneously with joining the common Nordic power exchange, Nord Pool), fuels used for 
electricity production was exempted from taxation, i.e. electricity is only taxed at the consumption level.

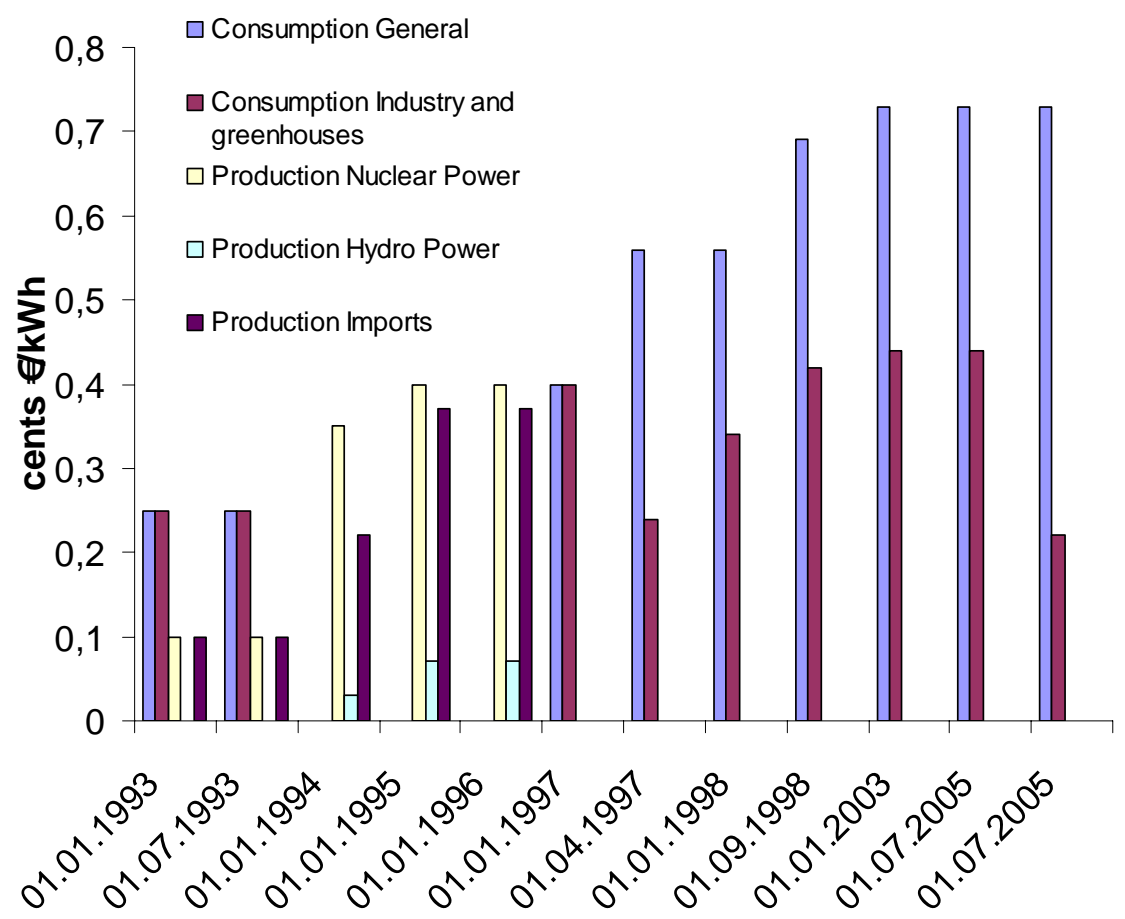

Figure 23: Electricity taxes in Finland. Source: Statistics Finland

Until 1997, the electricity tax level for households and industries was the same. Since 1997 the electricity tax is differentiated: a lower rate $(0.22$ cents $€ / \mathrm{kWh}$ from 2007) applies for industry and greenhouse cultivation, and a higher rate $(0.73$ cents $€ / \mathrm{kWh})$ for other consumers (households and the service sector). In addition, the largest energy intensive companies have reduced rates: if electricity and $\mathrm{CO}_{2}$ tax costs of an energy intensive company exceed $3.7 \%$ of its value added, it is entitled to a $85 \%$ refund of these taxes for the part that exceeds 50,000 $€$.

This implies that electricity prices in Finland, as in the other Nordic countries, differ for households and industrial consumers (Figure 24). Households have the highest prices, paying at least 30\% more than medium-scale industry throughout the observed period. 

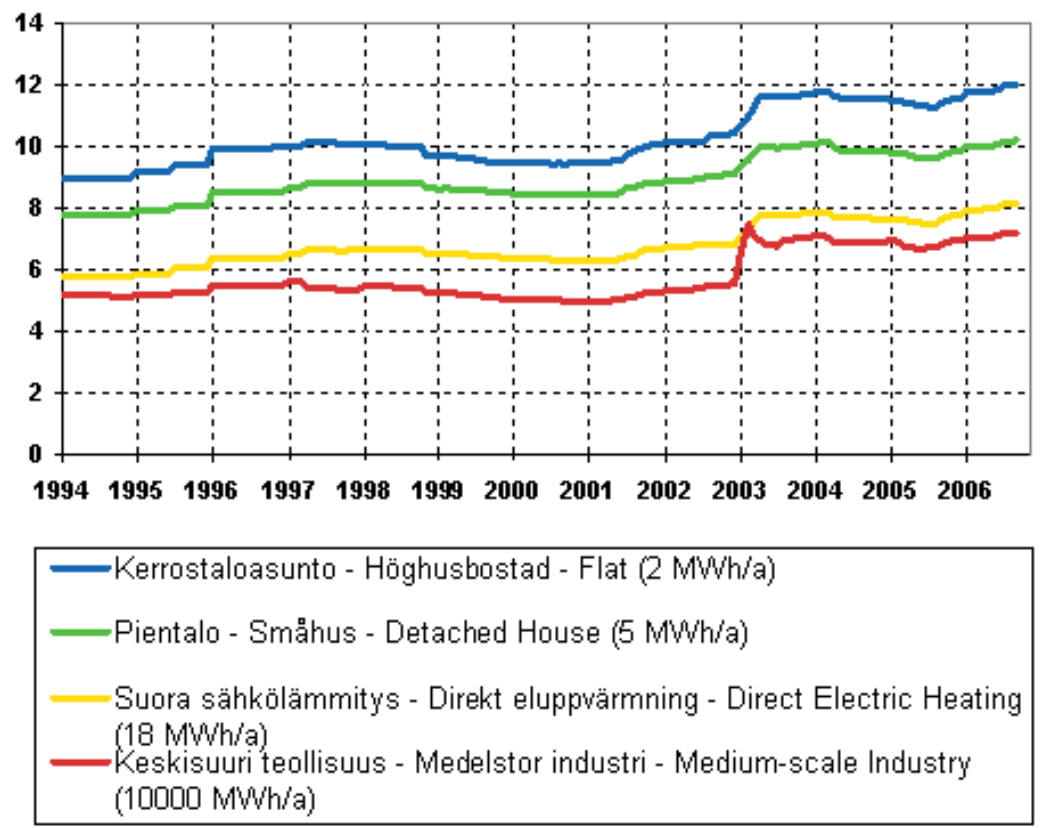

Figure 24: Price of Electricity by Type of Consumer 1994-2006, c/kWh.

Source: Finnish Energy Market Authority, www.stat.fi

The energy tax level and VAT for households has been almost stable with a small increase from 2.5 to 3 cents $€ / \mathrm{kWh}$ from 1998 to 2007 (Figure 25). The share of energy tax and VAT of the consumer price for households is around $24 \%$.

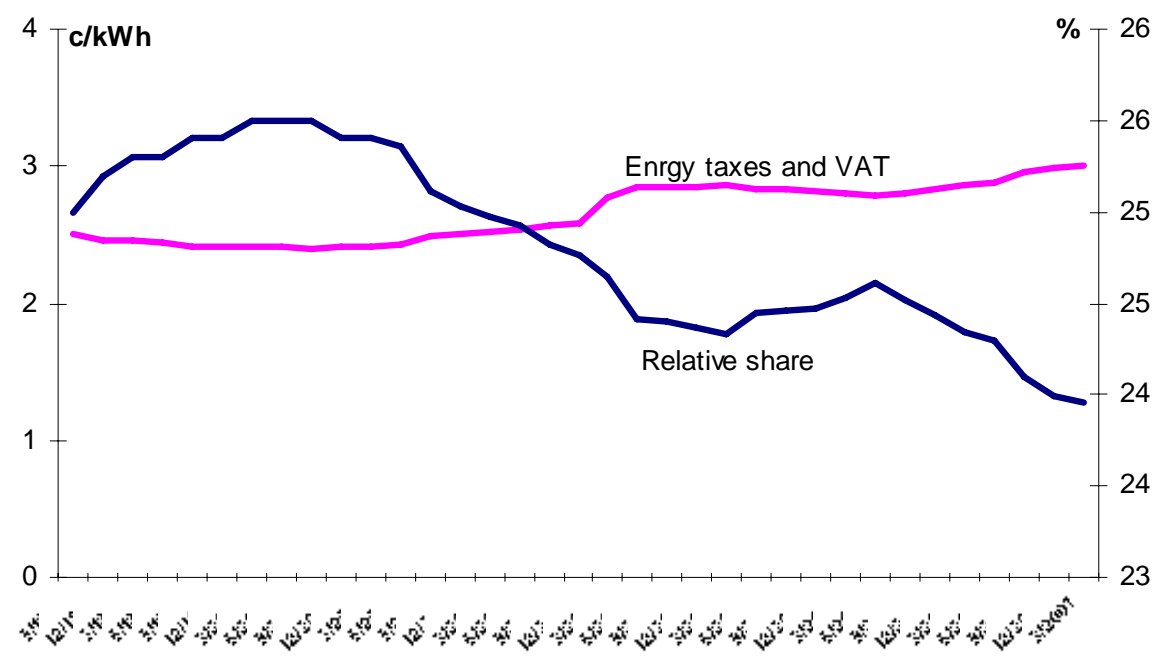

Figure 25: Excise taxes and VAT (pink line, left axes) included in consumer prices of electricity for households. The relative share of the consumer price is illustrated by the blue line / right axis.

Source: www.stat.fi 
The price for district heating to households in Finland has been very stable doing the last decade and the price differences to different types of household is very small (Figure 26).

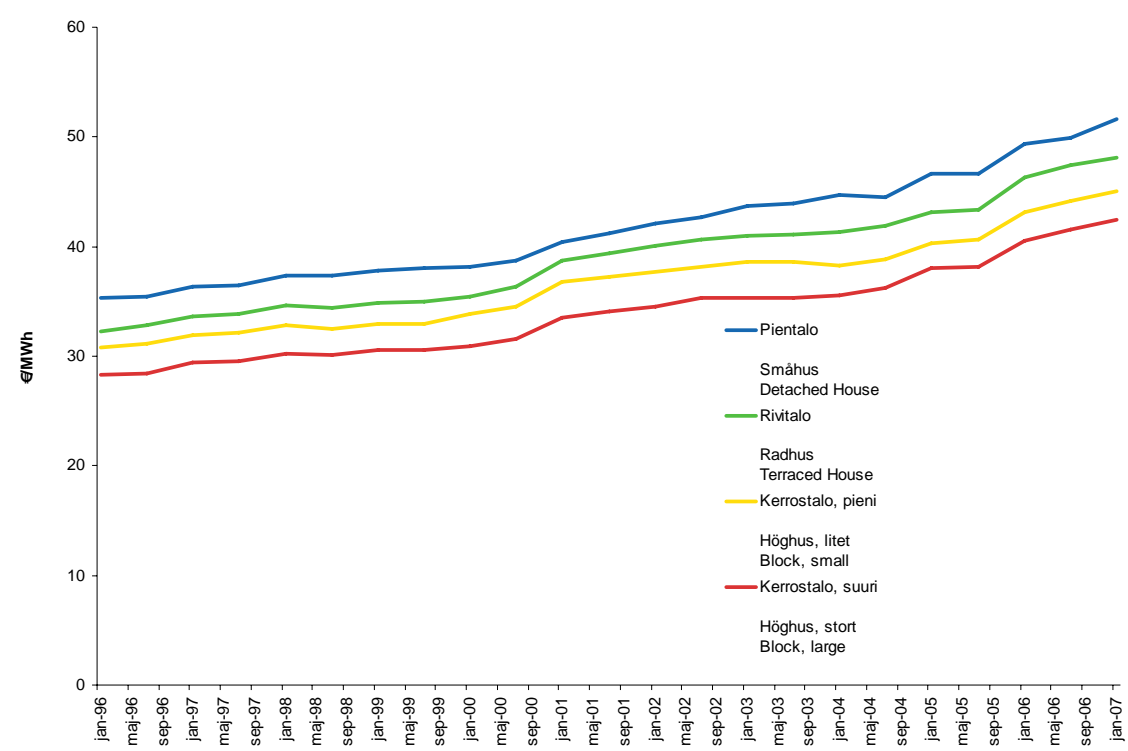

Figure 26: Price of District Heating by Type of Consumer, $€ / M W h$.

Source: Statistic Finland

Sweden

The price level for district heating in Sweden has been slightly increasing during the last 10 years (Figure 27). In average the increases in prices have been stable. However, large differences have been observed in different areas of Sweden.

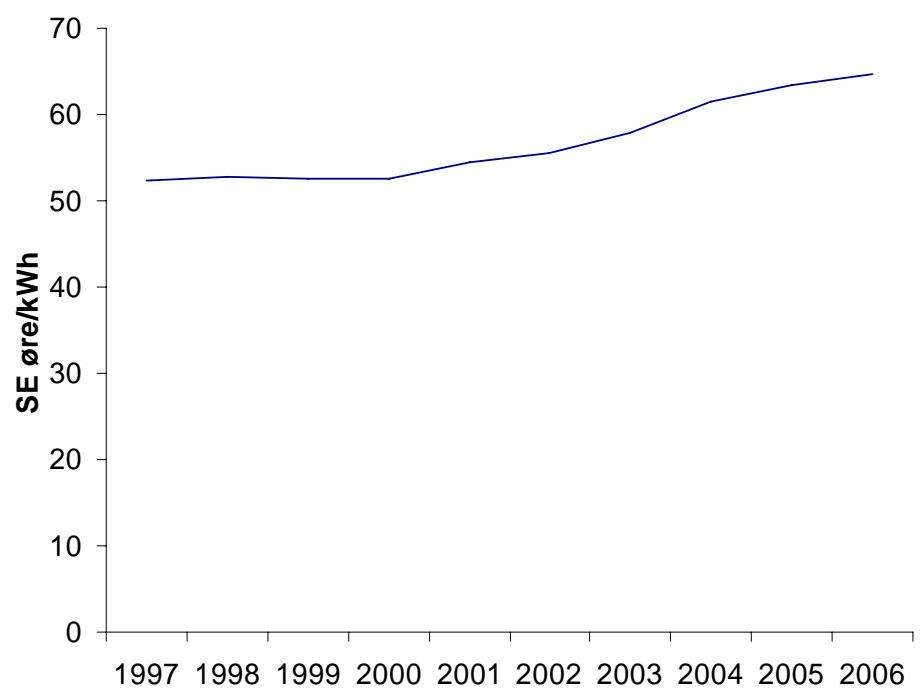

Figure 27: Average prices for district heating (including VAT, running price levels). Customer type: $193 \mathrm{MWh} / \mathrm{yr}$

Source: Energimyndigheten, SE. 
The Swedish energy taxes differ between fuel types and fuel uses. The manufacturing industry pays no energy tax on their fuel consumption. Similarly, fuels used in district heating and power generation are exempted from the energy tax. The electricity consumption tax is at a flat rate of SEK 0.265 per kWh. However, the manufacturing industry, agriculture (greenhouses) and forestry have a lower rate, SEK 0.05 per kWh.

For the households, the consumer price for fuel oil have increased during the last decade. Especially the share of CO2-taxes has increased (Figure 28).

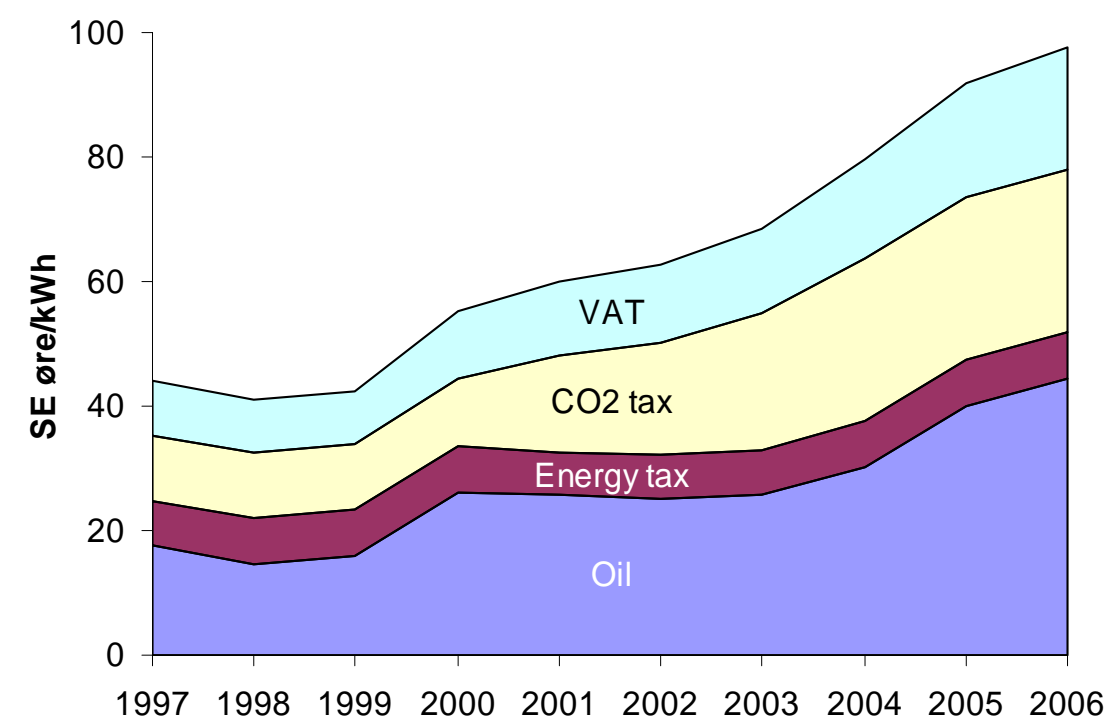

Figure 28: Average consumer prices for fuel oil for the average household consumer 1997-2006 (running price levels).

Source: Energimyndigheten, SE.

The Swedish household electricity price mainly consists of the electricity price, VAT and taxes. The relative share of the grid tariff in the total cost has decreased in the period, as this has not followed the general price growth.

Table 4 Real-term average prices (2006 prices). Real prices in öre/KWh and shares of total. Customer type: House 20A, 20000 kWh/yr; Source: Energimarknadsinspektionen, SCB and Skatteverket.

\begin{tabular}{lrr}
\hline & Real prices, øre/kWh & Share of total \\
\hline Electricity price & 45,87 & $37 \%$ \\
Network tariff & 23,24 & $19 \%$ \\
Electricity certificate & 3,44 & $3 \%$ \\
VAT and tax & 51,22 & $42 \%$ \\
\hline Total price & 123,09 & $100 \%$ \\
\hline
\end{tabular}


Development in the total electricity price for households in Sweden was stable in the last part of the 90ies, and increasing after the turn of the century as shown in Figure 29. The main growth in the total electricity price happens in the latter years, from 2003 and forth. The increase in the total electricity price is due to increases in VAT and taxes as well as in the wholesale electricity price. Furthermore the cost of electricity certificates has been added from the year 2003. However, the consumer share of the green certificate costs only make up a small share of the price increase. The grid payment (network tariff) has remained unchanged throughout the period.

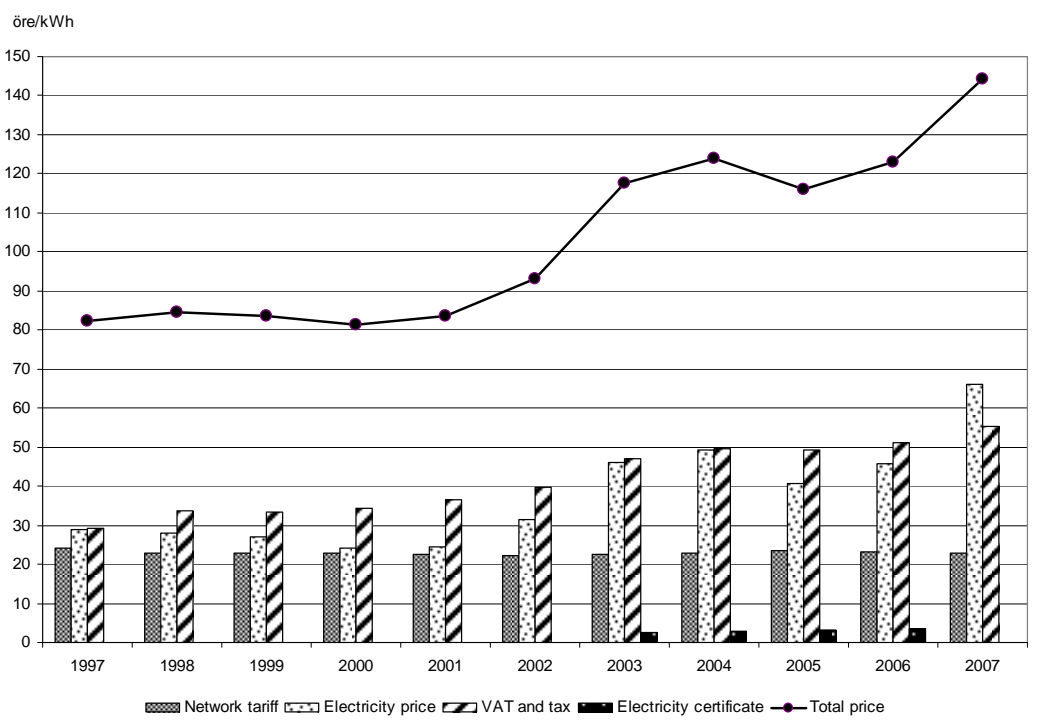

Figure 29: Real-term average prices (2006 price levels). Customer type: House 20A, $20000 \mathrm{kWh} / \mathrm{yr}$

Source: Energimarknadsinspektionen, SCB and Skatteverket.

\section{Norway}

In Norway the electricity tax has in general been increasing since 1980 (Figure 30). The tax is now at NOK 9.88 øre/kWh for households, but is has been as high as $10.23 \mathrm{NOK} ø r e / \mathrm{kWh}$ in 2001 . However, it is still at a low level compared with the other Nordic countries. 


\section{Forbruksavgift på elektrisitet}

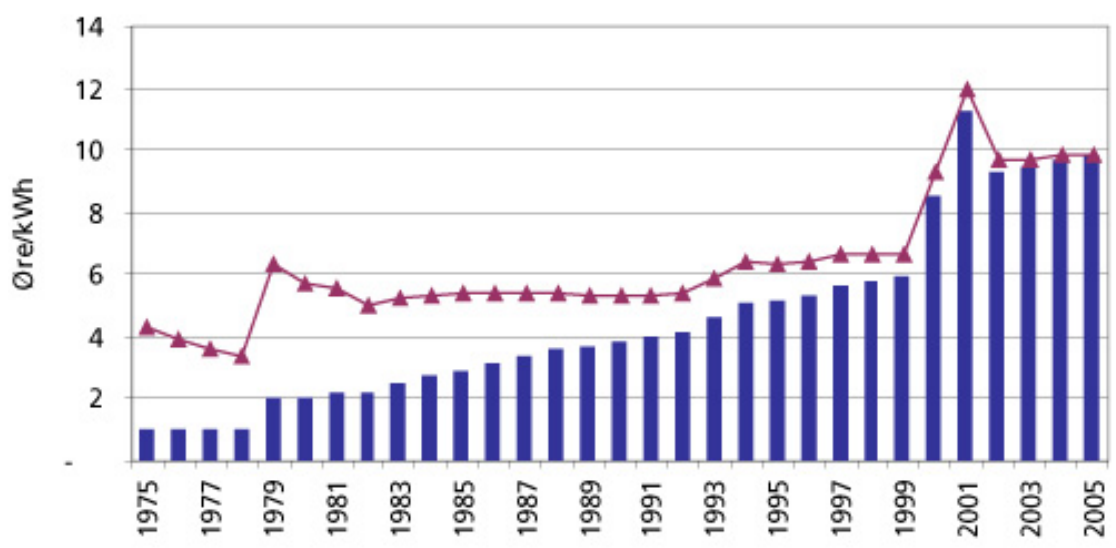
Figure 30: Development in the electricity tax. The broken line shows the development adjusted by the consumer index from 1998.

Source NVE, 2007.

The Norwegian electricity price for households is in general lower than in the other Nordic countries. The total electricity price has experienced a general increase since 1993, as in the figure below. The main price growth has taken place in the latter years starting in 2003. The increase in the total electricity price for households is due to increases in taxes and the wholesale electricity price. As in Sweden grid tariffs (Nettleie) have been stable throughout the period.

\section{Gjennomsnittlig kraftpris og nettleie, samt avgifter (husholdningskunder) \\ Kilde: NVE}

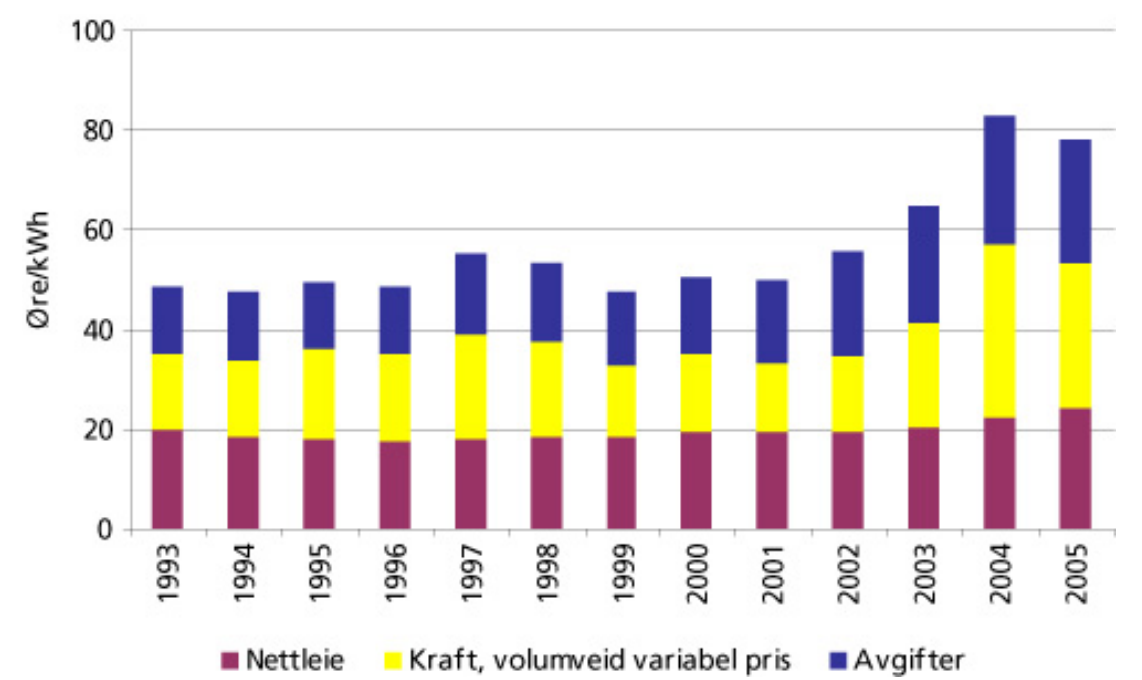

Figure 31: Average electricity price for households in Norway. 
As shown above the Norwegian household electricity price consists of almost equal shares of electricity price, grid payment and taxes. The grid payment has however not experienced the same growth as the other components, hence their share of the total price development has declined.

\section{Kraftpriser for ulike grupper i perioden 1993-2006}

Kilde: SSB

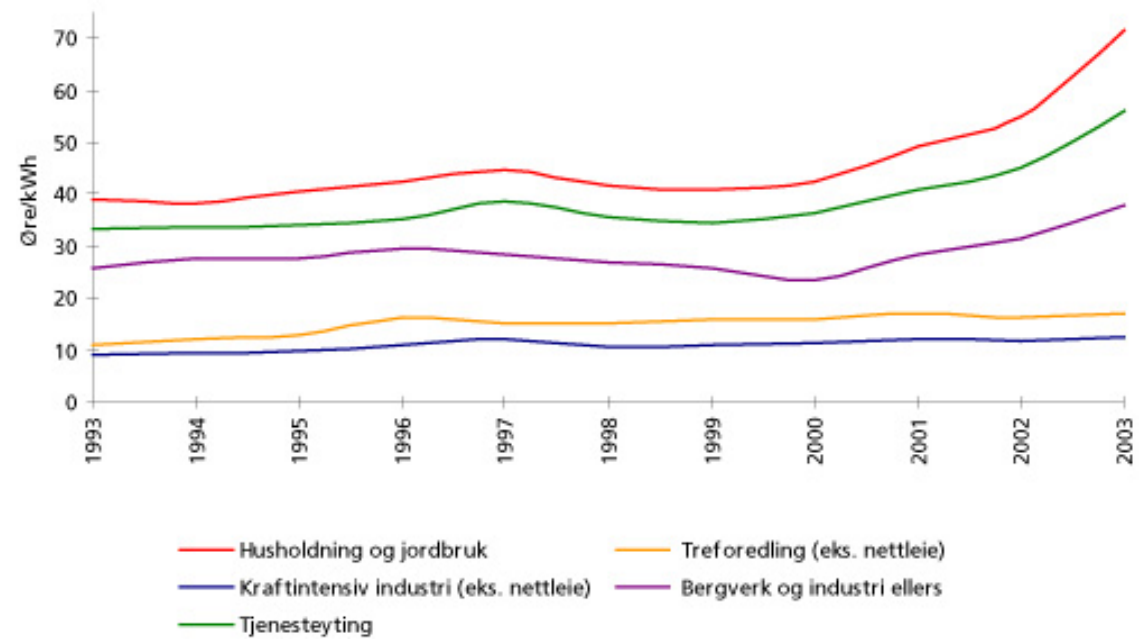

Figure 32: Energy prices for different groups in the period 1993-2003.

Source: SBB, NVE

In Norway electricity prices for households are significantly higher than the price paid by the industry. It is noticeable that the electricity price for the energy intensive industry has not increased much over the period, while prices for e.g. households increase significantly towards the end of the period. The reason for this is presumably that energy-intensive industries have long-term contracts with stable prices. The absolute price difference between households and industrial consumers is, however, not as large as in e.g. Denmark.

\subsection{Electricity supplier switching in the Nordic countries}

One way for the consumer to react to changes in electricity prices is by switching supplier. The level of switching activities has varied remarkably in the four Nordic countries (NordREG, 2005). The most active switching behaviour has been seen in Norway, followed by Sweden, Finland and Denmark. Iceland has been the last country to make all electricity consumers eligible to switch supplier, and it is still too early to say how the switching activities are. Also between sectors the level of switching activities has varied substantially. The household sector has the lowest activity.

In Norway 200.000 household consumers change supplier each year (NVE 2007). Almost 600.000 households and cottages use another sup- 
plier than the largest supplier in their local area. This is equivalent to $26 \%$ of the consumers.

Since 2003 the Danish households have been able to freely choose between the supply companies. However, less than $1 \%$ of the Danish households change electricity supplier each year. The low activity of changing supplier has tempted the supply companies to increase the electricity prices for households. In March 2007 the Danish Energy Regulatory Authority (DERA) ${ }^{19}$ had to intervene and order the supply companies to lower their household supply prices.

Also the type of contracts differs between the Nordic countries. Contracts linked to the spot price are widely used in Norway, whereas Swedish and Danish consumers mainly sign long-term contracts with fixed prices.

The use of log-term contracts may explain why the switching activity is low in some countries. However, there may be many other factors that can explain the different levels of switching activities. Among them are the share and importance of the net price of electricity in the final consumer price and household budget. As discussed above, the levels of consumption and energy prices vary considerably between the countries. Norway, which has the highest electricity consumption per capita, is also the country with the highest switching activity. This could be interpreted as an effect from the share of consumer budget, i.e. a small change in the electricity price has a major influence on the consumption budget in Norway and only a minor influence on the consumption budget in Denmark. This could explain why Norwegian consumers are more active in switching supplier and why Danish consumers are not.

\subsection{Similarities and differences between the Nordic countries}

The above descriptions of energy consumption and prices have shown that similarities and differences do exists between the Nordic countries. However, comparing consumption and prices between the different countries is a difficult task. Many underlying factors can be part of the reasons why differences are seen in the consumer prices and consumptions. Examples of such factors are differences in the market structures, supply and production conditions, available resources, and historical and energy policy issues. In addition, administrative obligations on the consumption of national fuels or energies may influence the final consumer price, e.g. the Danish mandatory connection to district heating in certain public supply area and the priority to distributed electricity generation (smallscale CHP and renewable energy). Therefore, the interpretation of the comparisons should be made with caution.

\footnotetext{
${ }^{19}$ http://www.energitilsynet.dk/english/
} 


\section{Consumption}

In order to understand the above suggested differences in price and consumptions the structure of the energy markets in the different countries must be taken in to account.

The foundation of the present fuel mix is historically determined. Through the last century, the energy sectors have been formed by the access to natural resources and by political priorities. Especially the development of the grid-dependent energies have been driven by central planning and heavily influenced by political priorities. This group of energies includes electricity, district heating and natural gas.

Renewable energy has gained massive support since the early 1990ies. Especially in the electricity sector, small scale renewables have been given priority whereas the supply market for conventional based power generation has been liberalised.

Large natural resources of geothermal energy in Iceland and hydropower in Norway, Sweden and Iceland made it natural to include these resources in the fuel mix, e.g. in Norway the electricity sector is almost exclusively based on domestic hydro resources.

Low electricity prices in the last century caused the households in Norway and partly also in Sweden to use electric panels for space heating.

\section{Consumer prices}

The Harmonised Index of Consumer Prices (HIPC) for electricity for each Nordic country shows that the volatility of the electricity price index has been considerably larger for Norway than for the other Nordic countries. The small variations in the electricity price index of the other countries, especially Denmark, are mainly due to a high level of energy levies and taxes with a flat rate for household.

As mentioned in Table 3 at page 41, in Denmark only around 15\% of the consumer price for electricity comes from the wholesale price of electricity. The remaining $85 \%$ are grid payments, taxes and VAT. Due to a flat rate for these taxes any fluctuations in the wholesale electricity price only gives minor fluctuations in the consumer price for the households.

Table 5: Consumer price level for electricity to households in the Nordic countries and the relative share of energy taxes and $\mathrm{VAT}^{20}$

\begin{tabular}{lcr}
\hline & Consumer price level cent $€ /$ kWh & VAT and energy taxes \\
\hline Denmark & 24 & $57 \%$ \\
Sweden & 13 & $42 \%$ \\
Finland & 12 & $24 \%$ \\
Norway & 8.5 & $33 \%$ \\
\hline
\end{tabular}

\footnotetext{
${ }^{20}$ Source: Energitilsynet (2007, DK), Energimarknadsinspektionen (2006, SE), Finnish Energy Market Authority (2006, Fin), NVE (2007, N).
} 
The levels of the consumer prices (especially for households) vary a lot between the Nordic countries (Table 5). The consumer price is almost three times higher in Denmark than in Norway.

As much as $57 \%$ of the consumer price for electricity to households in Denmark comes from energy taxes and VAT. In Finland only 24\% of the consumer price originates from energy taxes and VAT.

In addition, the shift in demand between fuels is highly dependent on the availability of substitutes. The price elasticity of electricity demand will increase with increasing availability of substitutes to electricity. Leth-Petersen, Halvorsen, Larsen and Nesbakken (2003) compare the energy markets in Denmark and Norway. Their results indicate that Danish households do not substitute between different energy sources for heating purposes, while Norwegian households do substitute between different energy sources for heating purposes, i.e. several heating equipments may be installed in a Norwegian household. The authors argue that this difference between Denmark and Norway originates from differences in institutional settings in the two countries.

Leth-Petersen, Halvorsen, Larsen and Nesbakken (2003) emphasize the fact that Denmark and Norway are very similar societies in terms of the organization of the society, but that there are large differences concerning the regulation of the energy market. Norwegian energy policy imposes few restrictions on the households and therefore the Norwegian households often have several types of heating equipment available. Almost $90 \%$ of the Norwegian households have the possibility to substitute between different energy types for heating purposes. In Denmark, however, the energy market has been submitted to extensive regulation and the Danish households typically only have access to one type of heating equipment. $65 \%$ of the Danish households do not have any possibility to substitute between energy types for heating purposes. Since the Norwegian households have better possibilities to substitute between different energy sources than Danish households, it is reasonable to assume that they are more sensitive to variations in the price of electricity than the Danish households.

The prices for district heating are often regulated and linked to electricity and fuel prices. Due to the limited amount of price data for district heating it is very hard to compare the prices and to make meaningful interpretations of the differences.

However, very stable district heating prices are observed for all countries although the price levels have been slightly increasing. This is mainly due to the fact that they are regulated based on average prices for alternative fuels and official price indexes. This implies that the short term fluctuations in the prices for alternative fuels are not seen in the price for district heating.

In conclusion, the level of regulation of the energy market influences the availability of substitutes, which in turn influences the price elasticity. 
From an energy policy point of view, this implies that using pricingpolicy to discourage household energy use should be more successful the less regulated the energy market is. 


\section{Energy Price Elasticities}

Consumers face a price which is a combination of the energy prices (deriving from cost of availability of fuel and further production costs), services (supply of energy, i.e. transmission) and taxes. Therefore, in general, energy levies and environmental taxes affect consumer prices of the energy. By estimating the relationship between changes in energy consumption and changes in the combined price (changes in energy prices and/or taxes) one is able to examine the effect of taxes on the energy consumption.

In the following chapter, special attention is given to the price elasticity of electricity demand, which is a measure of how much the demanded quantity of electricity responds to a change in the relative ${ }^{21}$ price of electricity. As a result of the ongoing political debate on the need for regulation of electricity consumption, the interest in the potential of using pricing policy to reduce energy consumption has increased (Nesbakken, 1999). Analyses of the price elasticity of electricity consumption can contribute to the understanding of this complex issue.

\subsection{Modelling electricity demand}

The interest in modelling energy markets increased significantly after the oil crisis in 1973. Since then, a substantial amount of resources have been devoted to estimate demand elasticities, i.e. the responsiveness of demand to other variables, in different markets. The demand elasticities are estimated in order to find out to what extent the demand reacts to variations in for example own price, income and prices on substitutes (cross price elasticity).

The demand for electricity, particularly in the household sector, has been thoroughly investigated by many researchers. Electricity demand at various levels of aggregation has been studied, and a large variety of model structures and econometric techniques have been applied.

\section{Model structure}

Electricity demand contains some special features that are difficult to model. The most important of these is the fact that consumers do not

\footnotetext{
${ }^{21}$ The term "relative price" means the percentage change in price. It is the price of energy in terms of another price level; the ratio of two prices. The elasticity measures the degree of the relationship between percentage changes in quantity demanded of the energy and percentage changes in its price.
} 
demand the electricity directly. Instead, it is the goods and the services that can be produced when electricity is used as an input that is demanded by the consumer. Since both electricity and electric appliances are needed to produce these goods and services, it is reasonable to assume that the consumers' short-run response to a change in the electricity price differs from the long-run response. In the short-run, the consumer may adjust the utilization rate of electric appliances. In the household sector, consumers who use electricity for space heating may for example lower the indoor temperature as a reaction to an increase in the relative price of electricity. In the long-run, the consumer may adjust the stock of appliances or change to or from alternative fuels when the relative price of electricity changes. In the household sector, the consumer may for example replace an electric heating system with district heating as a response to an increase in the electricity price. To what extent this special feature of electricity demand is taken into account in the econometric model varies substantially between different studies.

In the simplest models, the interdependence between the stock of appliances and the utilization rate of the appliances is not captured. Electricity demand is modelled as a function of electricity price, income and other relevant variables. The largest disadvantage with this kind of model structure is that no distinction is made between short- and long-run adjustments. In other types of simple model structures, a measure of the stock of appliances that use electricity is included as an explanatory variable in the model. However, no attempts to explain the observed level of equipment stock are made. The emphasis is instead on finding the factors that affect the utilization rate of the observed stock of appliances. Thereby, this model structure is limited to conclusions about short-run responses.

In order to make a distinction between the price elasticity in the shortrun and the price elasticity in the long-run, the demand for appliances that use electricity and the utilization rate of these appliances, must be estimated simultaneously. This model structure gives the largest amount of theoretical information about the nature of demand and gives statistically significant results to a larger extent than other model structures. In addition, the results from studies using this model structure are more consistent than results from studies using other model structures (Bohi and Zimmerman, 1984). On the other hand, in order to estimate the demand for electric appliances and the utilization rate of these appliances simultaneously, restrictive assumptions about price expectations have to be made. These assumptions imply that the results from the regression analysis must be interpreted with caution, which makes it difficult to draw definitive conclusions. Moreover, this model structure is more complicated to use and detailed data on stock and price of electric appliances is hard to find. For this reason, the simpler model structures are used far 
more frequently than model structures where the demand for electric appliances and their utilization rate are estimated simultaneously.

\section{Level of aggregation and functional form}

Another important difference between studies of electricity demand is the level of aggregation. In the majority of studies, aggregated time series data is used (Bohi and Zimmerman, 1984). Using aggregated data usually restricts the number of observations, which in turn limits the precision of the estimates. Moreover, consumption decisions are made on a micro level. Thus, consumption choices are better analyzed at a micro level. In addition it has been shown that studies using micro data generally give more precise and consistent results than studies using aggregated data (Bohi and Zimmerman, 1984). However, the possibilities to use micro data are restricted due to limited availability of data, in particular in other sectors than the household sector.

The choice of functional form also differs between studies. The objective when choosing functional form is to find the form that fits the data in the most accurate way. In the literature, linear and log-linear models are the most commonly used functional forms (Dahl, 1993).

\section{Explanatory variables}

The choice of explanatory variables used in the econometric model is highly dependent on the model structure and level of aggregation. However, including the price of electricity and a measure of income is a natural starting point. One important issue when modelling electricity demand is to determine what measure of electricity price that is the most appropriate one. This difficulty arises from the fact that electricity consumers meet a complicated rate schedule instead of one single price. Since it is difficult to include the effects of a rate schedule in an econometric model in a satisfactory way, the marginal or average price is used in most studies. Apart from measures of price and income, the price of a substitute for electricity, such as oil, is included in many studies in order to estimate the cross-price elasticities.

\section{Structural and institutional factors}

It is generally difficult to capture structural and institutional factors (such as industry mix and the level of market regulation) in econometric models. However, it is highly probable that these factors have a significant impact on the price elasticity of electricity demand. Thus, when comparing price elasticities between geographical regions or between different periods in time, the differences in structural and institutional settings must be considered. Due to the complexity of including them in the 
econometric model, the influence of these factors is often evaluated outside of the econometric analysis.

\subsection{Previous Research}

\section{Introduction}

In the Nordic region, several studies have been conducted in order to investigate the price elasticity of electricity demand. In the following section, empirical studies from Sweden, Norway and Denmark are briefly summarized. Evidence from Finland and Iceland are not presented since we have not found any relevant research concerning the price elasticity of electricity demand from either of these countries.

Andersen, Enevoldsen and Ryelund (TemaNord 2006:528) have estimated the energy elasticities in ten industrial sectors in Norway, Sweden and Denmark. They use panel regression analysis of price effects in other to analyse the impact of taxes on energy consumption and $\mathrm{CO}_{2}$ emissions. They estimate that the own price elasticities of electricity for the industry sectors are -0.1 for Denmark, -0.16 for Sweden and -0.28 for Norway, i.e. almost three times as high in Norway as in Denmark.

Andersen, Enevoldsen and Ryelund (2006) also estimate energy elasticities for other fuels used in the industries. Their findings are summarised in Table 6 below.

Table 6 Own-price elasticity of demand for sub-energy inputs in the industries. Source: Andersen, Enevoldsen and Ryelund (TemaNord 2006:528).

\begin{tabular}{lrrr}
\hline & Denmark & Norway & Sweden \\
\hline Oil products & -0.42 & -0.55 & -0.57 \\
Coal products & -0.37 & -0.57 & -0.59 \\
Natural gas & -0.11 & -- & $(-0.12)$ \\
Waste energy & -0.51 & -0.62 & $(-0.12)$ \\
Electricity & -0.10 & -0.28 & -0.16 \\
\hline
\end{tabular}

The results show that the estimated energy price elasticity for electricity is substantially lower than the corresponding own-price elasticities for the other fuels used in the industry.

Most other studies, that we have found, are national studies that focus on the household sector, and we can thus not compare price elasticities further between different sectors or between countries. However, studying household electricity demand is important since the household sector constitutes a considerable share (on average approximately 30\%) of the total electricity consumption in the Nordic region (Nordel Annual Statistics 2005). 
Sweden

Brännlund, Ghalwash and Nordström (2005) examine how an increase in energy efficiency affects consumption choices by Swedish households, and thereby the emissions of greenhouse gases. As a part of the analysis, they estimate the price elasticity of electricity used for space heating. Quarterly time series data for aggregated electricity consumption for the period 1980-1997 is used to estimate the price elasticity in a static model. The price elasticity is found to be -0.71 , and the authors point out that this result is in line with elasticities estimated in other studies on Swedish data.

In contrast to Brännlund, Ghalwash and Nordström (2005), Damsgaard (2003) uses micro data to estimate the price elasticity of household electricity demand. A short-run model, where demand for electricity is conditioned on the stock of electric appliances is applied to cross sectional data from 1997. The price elasticity is estimated to be between 0.92 and -1.35 for households without electric heating, between -0.54 and -0.72 for households with electric heating and between -0.37 and 0.79 for houses with mixed heating.

Andersson (1997) also uses micro data in order to estimate the price elasticity of household electricity demand. Cross sectional data from 1986 is used. The price elasticity for a single family with electric heating is estimated to -1.37 , which is very high in comparison to estimates of the short-run elasticities from other studies. However, Andersson (1997) argues that the estimated price elasticity could be interpreted as a longrun price elasticity since the electricity price has been rather constant over time in the different geographical areas that are included in the study. Consequently, the electricity consumers are assumed to have adjusted their stock of electric appliances to the prevailing price level.

\section{Norway}

Halvorsen and Larsen (2001) estimate both the short-run and the long-run price elasticities for household electricity consumption in Norway using annual micro data from the period 1975-1994. The data contains information on each household's electricity consumption, the purchase of new household appliances, the current stock of appliances and detailed information on the characteristics of each household. Note that Halvorsen and Larsen (2001) only study the price elasticity of demand for electricity for household appliances. That is, they exclude the demand for electricity for space heating. The estimated short-run price elasticity is -0.433 and the estimated long-run elasticity is -0.442 . Since it is possible to adjust the stock of appliances in the long-run, it may seem surprising that the longrun price elasticity is not much higher than the corresponding price elasticity in the short-run. However, Halvorsen and Larsen (2001), emphasize that there is no substitute to electricity for household appliances in Nor- 
way. Thus, the households cannot reduce their electricity consumption by, for example, purchasing a gas stove. Hence, this would explain the small difference between the short-run and the long-run price elasticity.

In Norway there are, however, alternative fuels for space heating. Therefore, it is reasonable to expect that the difference between shortand long-run elasticities for household electricity demand for heating purposes is larger than the difference between short- and long-run elasticities for household electricity demand for electric appliances (Halvorsen and Larsen 2001).

Johnsen (2001) also examines to what extent electricity demand within the Norwegian household sector is sensitive to changes in the price. Weekly data from 1994 and 1995 are used to estimate the price elasticity. Johnsen (2001) emphasizes that weekly data conveys information about the short-run adjustments resulting from a change in the price of electricity that can possibly be lost in data with lower periodicity. On the other hand, the long-run adjustments are not captured when weekly data is used. Thus, the estimated coefficients should be interpreted as short-run elasticities. Johnsen (2001) concludes that the price elasticity lies between $-0,05$ and $-0,35$ for the sample. Furthermore, Johnsen (2001) finds that the price elasticity varies with the price level (the higher the price level, the higher the price elasticity).

Using micro data containing information about energy consumption and characteristics of the households from 1993-1995, Nesbakken (1999) measures the price elasticity of household electricity consumption in Norway. The price elasticity is estimated to be -0.57 for $1993,-0.33$ for 1994 and -0.53 for 1995.

\section{Denmark}

In order to show how regulations of the households may reduce their ability to benefit from changes in relative energy prices, Leth-Petersen, Halvorsen, Larsen and Nesbakken (2003) compare the structures of household energy demand in Norway and Denmark. The Danish data contains information about 1931 households observed one time each in one of the years 1994, 1995 or 1996. All the households in the survey use district heating. In Denmark, the houses that use district heating do not have access to the gas grid, as explained in Chapter 2 above. Furthermore, installation of electric heating as the primary heating system is banned. Thus, it is expected that all households in the sample only use electricity for domestic appliances. The estimated long-run price elasticity of electricity demand in this study is -0.75 . 


\section{Summary of results}

The estimated price elasticities of household electricity demand are summarized in the following table (Table 7):

Table 7 Summary of estimated price elasticities of household electricity demand from the literature

\begin{tabular}{|c|c|c|c|c|c|c|}
\hline Country & Study & $\begin{array}{l}\text { Sample } \\
\text { period }\end{array}$ & Sector & $\begin{array}{l}\text { Data type } \\
\text { Time series } \\
\text { (TS)/ Cross- } \\
\text { section (CS)/ } \\
\text { Panel (P) }\end{array}$ & $\begin{array}{l}\text { Level of } \\
\text { aggregation } \\
\text { Aggregated (A)/ } \\
\text { Disaggregated } \\
\text { (D) }\end{array}$ & $\begin{array}{l}\text { Estimated price } \\
\text { elasticity } \\
\text { (Long-run in parenthe- } \\
\text { sis) }\end{array}$ \\
\hline \multirow[t]{3}{*}{ Sweden } & $\begin{array}{l}\text { Brännlund, } \\
\text { Ghalwash, } \\
\text { Nordström } \\
\text { (2005) }\end{array}$ & 1980-1997 & $\begin{array}{l}\text { Household (only } \\
\text { space heating) }\end{array}$ & TS & A & -0.71 \\
\hline & $\begin{array}{l}\text { Damsgaard } \\
(2003)\end{array}$ & 1997 & Household & cs & D & $\begin{array}{l}-0.92--1.35 \\
\text { (households } \\
\text { without electric } \\
\text { heating) } \\
-0.54--0.72 \\
\text { (households with } \\
\text { electric heating) } \\
-0.37--0.79 \\
\text { (households with } \\
\text { mixed heating) }\end{array}$ \\
\hline & $\begin{array}{l}\text { Andersson } \\
\text { (1997) }\end{array}$ & 1986 & $\begin{array}{l}\text { Household (only } \\
\text { households with } \\
\text { electric heating) }\end{array}$ & CS & D & -1.37 \\
\hline \multirow[t]{3}{*}{ Norway } & $\begin{array}{l}\text { Halvorsen, } \\
\text { Larsen (2001) }\end{array}$ & 1975-1994 & $\begin{array}{l}\text { Household } \\
\text { (except space } \\
\text { heating) }\end{array}$ & $\mathbf{P}$ & D & $\begin{array}{l}-0.433 \\
(-0.442)\end{array}$ \\
\hline & $\begin{array}{l}\text { Johnsen } \\
\text { (2001) }\end{array}$ & 1994-1995 & Household & $\mathbf{P}$ & D & $-0.05--0.35$ \\
\hline & $\begin{array}{l}\text { Nesbakken } \\
\text { (1999) }\end{array}$ & 1993-1995 & Household & cs & D & $\begin{array}{l}-0.57(1993) \\
-0.33(1994) \\
-0.53(1995)\end{array}$ \\
\hline Denmark & $\begin{array}{l}\text { Leth- } \\
\text { Petersen, } \\
\text { Halvorsen, } \\
\text { Larsen and } \\
\text { Nesbakken } \\
\text { (2003) }\end{array}$ & 1994-1996 & $\begin{array}{l}\text { Household } \\
\text { (except space } \\
\text { heating) }\end{array}$ & CS & D & $(-0.75)$ \\
\hline
\end{tabular}

All estimated price elasticities are negative. This result supports standard economic theory expecting consumption to decrease with an increase in price. Furthermore, the vast majority of the estimated price elasticites lie between 0 and -1 , which suggests that the price elasticity of the household electricity demand is inelastic. That is, a change in the price of electricity causes a smaller proportionate change in the demand for electricity. Note, however, that Andersson (1997) estimates the price elasticity in Sweden to be elastic, and that Damsgaard (2003) finds that the price elasticity might be elastic for households that do not have electric heating. Nevertheless, the Nordic Competition Authorities (2003) consider the price elasticity of household electricity demand to be inelastic. Furthermore, the Nordic Competition Authorities (2003) refer to Statistics Norway that estimates the short-run price elasticity of household electricity 
demand to be -0.05 , and the corresponding long-run price elasticity to lie between -0.20 and -0.25 .

In general, the above summarized results from Sweden, Norway and Denmark seem to be in line with the price elasticities suggested in comprehensive surveys of the literature on electricity demand from other parts of the world. In these surveys, estimates from a wide range of studies have been examined. Taylor (1975) concludes that the short-run elasticity of electricity demand is -0.2 and that the long-run price elasticity is -0.9. However, Taylor (1975) does not make a distinction between different sectors. Bohi and Zimmerman (1984) come to the conclusion that the short- and long-run price elasticity of household electricity demand are -0.2 and -0.7 respectively. Dahl (1993) concludes that the short-run price elasticity of the household sector is lower (in absolute terms) than 0.5 and that the long-run price elasticity of the household electricity demand is somewhere between -0.7 and -0.9 . Thus, all these extensive surveys suggest that electricity demand is inelastic and that it is more elastic in the long-run than in the short-run.

\section{Comparisons of Sweden, Norway and Denmark}

The estimated energy price own elasticities found by Andersen, Enevoldsen and Ryelund (TemaNord 2006:528) indicates large differences for the industry sectors in Norway, Sweden and Denmark. The own price elasticities of electricity is almost three times as high in Norway as in Denmark.

For the household sectors, we are not able to draw any conclusions about the possible differences in price elasticities between the Nordic countries solely on the basis of the above summarized empirical studies. Firstly, the number of studies is very limited. Secondly, the studies show too many differences regarding the modelling of electricity demand, cf. the discussion in section 3.1, in order to constitute a reliable foundation for comparison.

One important difference between the studies is the choice of model structure. Different model structures applied to the same data set produce different estimates of the price elasticity (Halvorsen, Larsen and Nesbakken 2001). Therefore, it is difficult to compare results from models differing in model structure. The time horizon of the estimated price elasticities also differs between the above summarized studies. That is, some studies estimate the short-run price elasticity whereas others estimate the longrun effects or both the short- and long-run effects. Further, the definitions of short-run and long-run are not consistent between all studies.

Moreover, some models are applied on aggregated time-series data while others are applied on disaggregated cross-sectional or panel data. According to Halvorsen, Larsen and Nesbakken (2001), the level of aggregation of the data has a decisive influence on the obtained results. Dahl (1993) shows that studies on cross-sectional data tend to find a more 
elastic response to price changes than studies on time-series data. Another important difference between the studies is the set of explanatory variables. Excluding explanatory variables that are correlated with included explanatory variables, produces biased estimates of the included variables (Halvorsen, Larsen and Nesbakken, 2001). That is, if variables that are correlated with both the demand for electricity and the price of electricity are excluded, the estimated price elasticity of electricity demand is biased. Thus, too far-reaching conclusions should not be drawn from comparisons between price elasticities produced by models including different explanatory variables.

Apart from being different concerning the features of electricity demand modelling discussed in section 3.1, the studies also differ with regard to data sample and sample period. Although all of the above summarized studies examine the household sector, there are important differences as to what the electricity is used for. For example, in some of the studies only the demand for electricity for space heating is investigated.

In conclusion, for households it is impossible to determine whether the observed differences in price elasticity between Sweden, Norway and Denmark should be considered as true differences or if they originate from differences in the modelling of the electricity demand, data sample and sample period.

\subsection{Econometric Analysis - Households}

\section{Introduction}

In order to obtain comparable estimates of the price elasticities for Nordic households' use of electricity, we conduct our own econometric analysis. We apply a simple log-linear model on monthly aggregated data from the period January 1996-July 2006 with the objective to estimate short-run price elasticities. Due to the limited availability of monthly data on electricity consumption, we exclude Iceland from the analysis. In the econometric model, electricity consumption is explained by GDP and the price of electricity. As discussed above, modelling electricity demand is a complex issue. Our simple log-linear econometric model should thus be considered as a strong simplification of electricity demand. The use of aggregated data further restricts the analysis. Since consumption decisions are made on a micro level it is possible that important explanatory variables are left out when aggregated data is used. The exclusion of these explanatory variables could produce biased estimates of the price elasticity. In conclusion, the simplicity of the econometric model and the restricted availability of detailed data on the price and consumption of electricity make it necessary to interpret the results generated by our model with great caution. 


\section{Variables}

\section{Dependent variable}

The monthly data on electricity consumption is measured in TWh and is obtained from Svensk Energi (Sweden), Statistics Norway (Norway), Energinet (Denmark) and Energia (Finland). The data is not made in exactly the same way for all of the four countries. The Swedish data on electricity consumption includes the total consumption of households and services. The Norwegian and Finnish data include the total consumption of households, services and the non energy-intensive industry. The Danish data includes the total national electricity consumption. These differences should be kept in mind when interpreting the results. All series of electricity consumption are adjusted for season and temperature, except the Danish series that is only adjusted for season.

Explanatory variables

Quarterly data on real GDP is obtained from the Statistical Bureaus in the Nordic Countries. As price variable, we use the Harmonised Index of Consumer Prices (HIPC) for electricity for each country. This data is obtained from Eurostat and we have adjusted these series for inflation by using the HIPC for all goods in each country. The HIPC for electricity is a measure of the electricity price that households face. As described above, the electricity consumption variable that is included in the model measures the electricity consumption for a wider sector than the household sector. Thus, the HIPC for electricity is a problematic choice of price variable. However, it is the best measure of electricity price that we have found. The development over time of the HIPC for electricity adjusted for inflation is shown in the figure below.

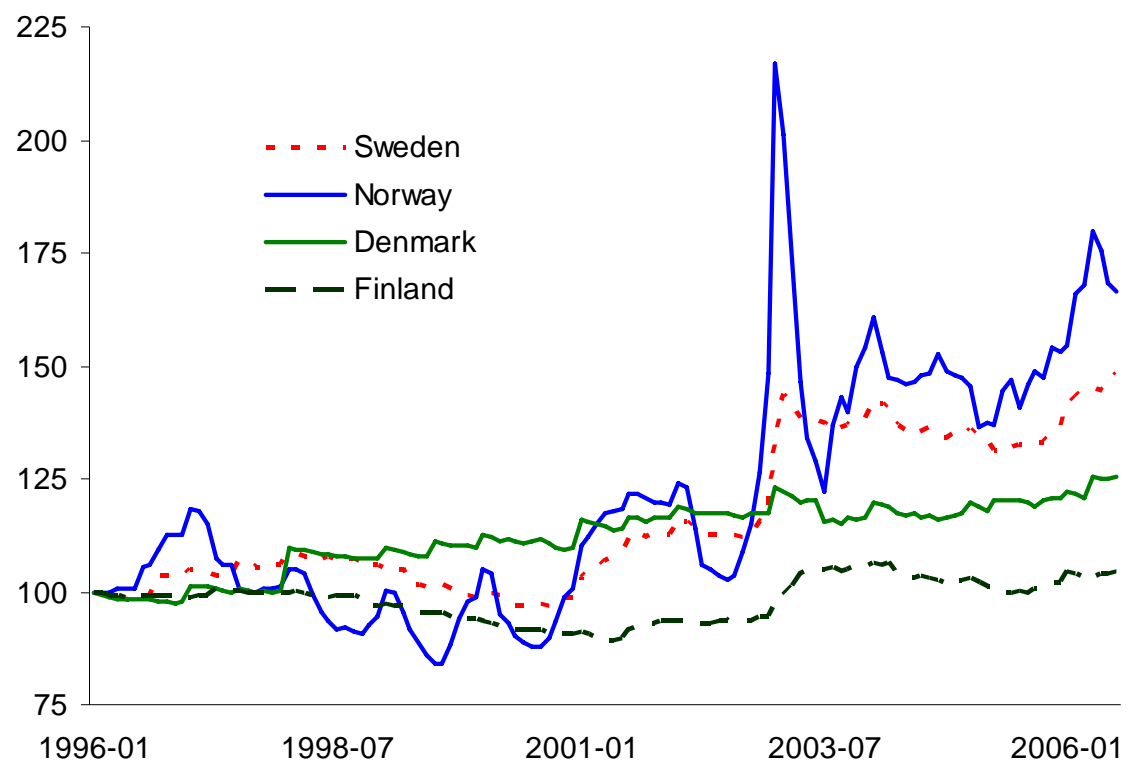

Figure 33: Development of the index for HIPC for electricity over time. Source: Eurostat. 
All the HIPC indexes for electricity show a positive trend starting around year 2002. Measured over the entire period Jan 1996 - July 2006, the electricity price increased in all of the Nordic countries. However, the magnitude of the price increase differed substantially between the four countries. In total, the electricity price in Norway increased with almost $70 \%$ over the period, whereas the corresponding price increase amounted to less than $5 \%$ in Finland. In addition, the volatility of the electricity price index is considerably larger for Norway than for the other Nordic countries. The small variations in the electricity price index of the other countries, especially Finland, could possibly make it difficult to find a relationship between electricity price and consumption.

In accordance with standard economic theory, we expect electricity consumption to respond positively to an increase in GDP and negatively to an increase in the price of electricity.

\section{Econometric model}

We employ the following econometric model:

$$
\ln Y_{t}=\alpha_{0}+\alpha_{1} \ln G D P_{t}+\alpha_{2} \ln P_{t}+u_{t}
$$

Where $Y_{t}$ is the monthly electricity consumption (TWh)

$G D P_{t}$ : index of $\left(G D P_{q, t-1}+G D P_{q, t}+G D P_{q, t+1}\right) / 3$, where $G D P_{q, i}$ is quarterly data on GDP.

$P_{t}$ : index of $\left(P_{t}+P_{t-1}+P_{t-2}+\ldots+P_{t-11}\right) / 12$, where $P_{i}$ is monthly data on electricity price.

\section{Results}

Using the statistics computer program SPSS, we run separate regressions for each of the four countries. The results are summarized in the table below ${ }^{22}$.

Table 8 Summary of results from the regression analysis.

\begin{tabular}{llrrrr}
\hline & & Sweden & Norway & Denmark & Finland \\
\hline $\mathbf{G D P}_{\mathbf{t}}$ & $\alpha_{1}$ & $0.330^{\star *}$ & $0.592^{\star *}$ & $0.467^{\star *}$ & $0.804^{\star *}$ \\
$\mathbf{P}_{\mathbf{t}}$ & $\alpha_{7}$ & -0.057 & $-0.164^{\star *}$ & -0.127 & $0.024^{\star *}$ \\
& $\mathbf{R}^{2}$ & 0.143 & 0.661 & 0.398 & 0.930 \\
\hline
\end{tabular}

** Significant at a $1 \%$ level

\footnotetext{
${ }^{22}$ In order to assure the reliability of the results, we have conducted standard tests for heteroscedasticity, autocorrelation and the degree of multicollinearity between the explanatory variables.
} 
All the estimated income elasticities are of the expected sign and significantly different from zero. This result thus suggests that electricity consumers in all Nordic countries respond positively to an increase in GDP. Further, in all the countries, the GDP variable has a larger influence on the electricity consumption than the electricity price does.

The value of $R^{2}$, which shows to what extent the variations in electricity consumption are explained by the variations in GDP and electricity price, differs widely between the four countries (from 14.3\% in Sweden to $93 \%$ in Finland). It is reasonable to assume that the large differences in the value of $R^{2}$ stem from the fact that the consumers' sensitivity to variations in GDP vary between the Nordic countries. Swedish consumers seem to be the least sensitive to variations in GDP and the regression on the Swedish data also has the lowest value of $R^{2}$. The Finnish consumers seem to be the most sensitive to variations in GDP and the regression on the Finnish data consequently has the highest value of $R^{2}$.

The only price elasticity that has the expected sign and is significantly different from zero is the estimated price elasticity for Norway, which amounts to -0.164 . In other words, in Norway, a $1 \%$ increase in the electricity price, results in a $0.164 \%$ decrease in the electricity consumption.

The estimated price elasticities for Sweden and Denmark; -0.057 and -0.127 respectively, are both of the expected sign. However, none of the estimated price elasticites are significantly different from zero. Consequently, we cannot determine whether the Swedish and Danish electricity consumers respond to variations in the price of electricity.

The estimated price elasticity for Finland, 0.024, is not of the expected sign. It seems as if the Finnish electricity consumption increases when the electricity price increases, which contradicts standard economic theory. It is therefore surprising that the estimate of the Finnish price elasticity is significantly different from zero. This effect could perhaps be explained by the simultaneity problem. If the price and the demand are determined simultaneously, a demand increase drives up the price. Since our econometric model does not capture this feature, it looks like the increase in demand results from the increase in price, and not the other way around.

For each of the four countries, the figure below shows the 95\% confidence interval for the estimated price elasticity. 


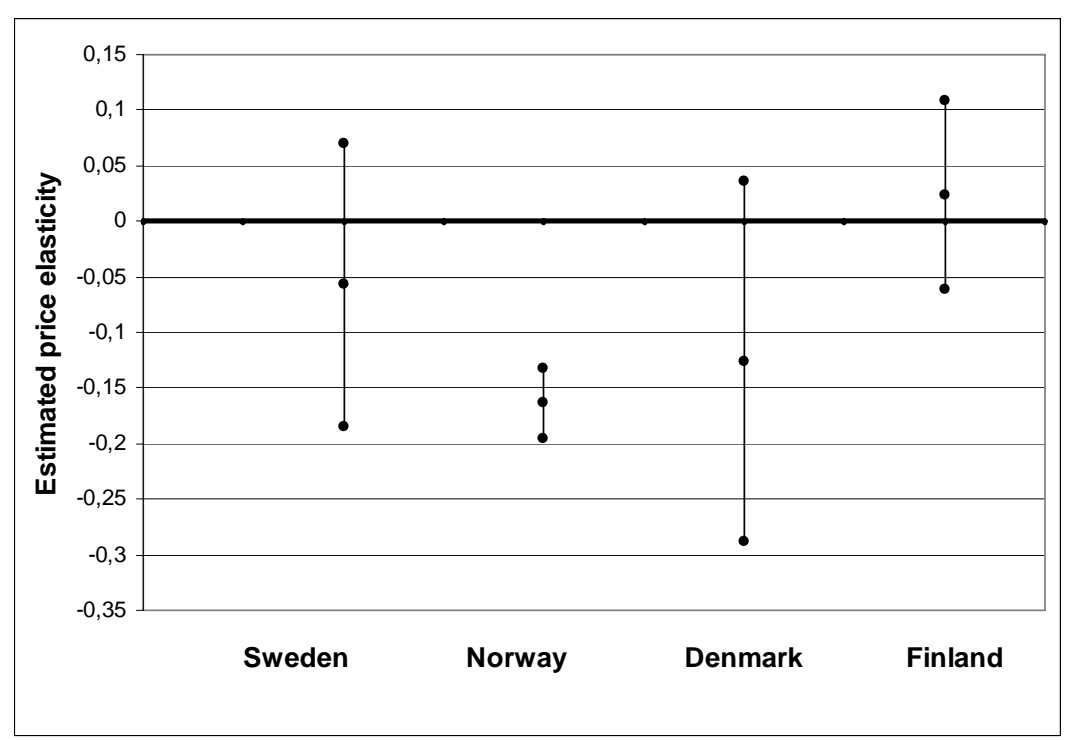

Figure 34: A 95\% confidence interval for the estimated price elasticities. Source: own calculations.

The figure clearly shows that the $95 \%$ confidence interval in Norway is smaller than the other confidence intervals, which illustrates that the price elasticity of electricity demand can be determined with greater certainty for Norway than for the other countries. In addition, the point estimate of the Norwegian price elasticity is lower than the other point estimates (0.164 in comparison to $-0.057,0.127$ and 0.024$)$. This result suggests that the Norwegian consumers are the most price sensitive consumers on the Nordic electricity market.

The high price elasticity for Norwegian households is in line with Andersen, Enevoldsen and Ryelund's (TemaNord 2006:528) estimates for the industry sectors. For Denmark the industry and household estimates are within the same level. One could have expected that the large differences in taxation between household and industry would influence the estimated elasticities (cf. our discussion in Chapter 2.4 on consumer prices).

Moreover, it should be remarked that the resulting elasticities of our econometric model are relatively lower than the elasticities of the studies, which have been described before. But in fact, these results may not be compared since our model refers to the household sector whereas the elasticities deriving from different literature described before where based on the industry sector. 


\section{Post analysis}

We have complemented the above econometric model with a regression with two price variables; $\mathrm{P} 1$ and $\mathrm{P} 2$ respectively. $\mathrm{P} 1$ is the average price during the last six months and $\mathrm{P} 2$ is the average price during the six months before then. The results from this regression strengthen the above drawn conclusion about Norwegian consumers' price response.

In addition, the results indicate that Swedish consumers respond negatively to increase in P2. In other words, it seems as if the Swedish consumers do adjust their electricity consumption to changes in price, but with some time delay. The Finnish consumers appear to react negatively to a price increase with the same time delay as the Swedish consumers. However, the Finnish consumers seem to react positively to an increase in P1, which complicates the analysis of the Finnish price elasticity. Finally, none of the Danish price variables are significantly different from zero. This is to say that the Danish consumers do not seem to respond to changes in the price of electricity. However, it is important to bear in mind that the Danish data on electricity consumption includes the total consumption of all sectors, whereas the price variable only shows the price that the household sector faces. It is possible that this discrepancy between the data on consumption and price widens the confidence interval for the estimated price elasticity and thereby increases the significance level at which it can be accepted. In addition, the discrepancy might bias the estimation of the price elasticity.

\subsection{Conclusions from the econometric analysis}

In summary, the simplicity of our econometric models and our insufficient data set prevent us from drawing definitive conclusions about the price elasticities in the Nordic countries. However, our results suggest that the Norwegian electricity consumers are the most price sensitive consumers on the Nordic electricity market. We cannot determine whether, or to what extent, the electricity consumers in the other Nordic countries are sensitive to changes in the price of electricity. However, our results indicate that it is possible that the electricity consumers in Sweden react negatively to increases in the electricity prices, but with at least six months delay.

Worth noticing is that since the oldest price of electricity included in our econometric analyses is the price 11 months ago, all estimated price elasticities should be regarded as short-run price elasticities. Consequently, we cannot draw any conclusions about the long-run price elasticities on the Nordic electricity market on the basis of our results. However, in the long-run, when the consumers have time to adjust their stock of electric appliances to the prevailing price of electricity, the results may be 
taken to support the hypothesis that it is reasonable to assume that the price elasticity is negative in all of the Nordic countries.

The observed differences can also be explained by differences in electricity supply contract structures in the Nordic countries. Many consumers have fixed price contracts where the price is adjusted 2-4 times per year. Also the amount of consumers with spot price agreements varies between the countries.

The can be other reasons why the power consumption in Norwegian household is more price elastic than in the other Nordic countries. As described in Chapter 2 electric heating is widely used in Norwegian households and it is relatively easy to respond to short-term fluctuation by shifting load or by using alternative heating appliances. In addition, Norwegian consumers are used to observe price fluctuations (Figure 33) due to the relative large share of the consumer price that originate from the wholesale price (Table 5). 



\section{Environmental effects of energy policy instruments}

This following chapter describes the theoretical background of different energy policy instruments used in the Nordic countries. Moreover, a small description of the historical development of the countries' energy policy and their use of the different policy instruments is given.

By comparing the Nordic countries' differences in implementation of the diverse policy instruments with the data analysis of the report's remaining chapters, it will be possible to draw conclusions on the environmental and economical effects of these instruments.

Focus of this chapter's analysis will be the environmental effects, especially the effect on $\mathrm{CO}_{2}$ emission level within the electricity sector. The increase in the utilisation of renewable energy sources is of course an important environmental effect as well, which could be investigated in detail. But we assume that a general reduction of $\mathrm{CO}_{2}$ emissions due to a change in the generation mix will indirectly bring along an increase in renewable energy capacity.

Finally, to also link this chapter with our beforehand presented analysis of the price elasticities of electricity consumption (in Chapter 3); we introduce a case study, which will illustrate the effects of the different Nordic countries pricing policies on $\mathrm{CO}_{2}$ emission levels.

\subsection{Historical development of Nordic energy policies}

In general, policies are formed in a dynamic context with conflicting and moving demands where targets and priorities change over time. In the Nordic countries, direct energy policies and policies indirectly affecting the energy sector, show substantial similarities in their historical development, although there differences due to some specific national goals and priorities can be observed as well.

Over time, new policy issues and targets appear or move up on the agenda. However, "old" targets seem not to disappear completely from the political agenda, although the priorities change over as well as by country.

The main energy policy targets in all the Nordic countries have always been efficiency and security of supply. Efficiency entails cost-efficiency, competitive prices, adequate regulation of networks as well as efficient investments and trades. 
Additionally, environmental concerns related to the energy sector have been high on the agenda for decades. In the early 1970ies, local air pollution was an important issue which lead to emission regulation measures of particles and $\mathrm{SO}_{2}$. Due to the oil crises in the late 70ies and early 80ies, the focus changed to the issue of security of supply. Energy policies were refocused and aimed at reducing oil dependencies of the economies. In Denmark, power generation was switched from oil to coal, and at the same time period. Sweden and Finland built up their nuclear power capacities to reduce oil dependency.

The end of the 80ies marked the start of the deregulation era, followed by demands for lower energy prices from energy intensive industries against the background of surplus capacity and long-term marginal cost pricing of energy.

Throughout the 90ies, although deregulation continued to be a high priority, the issue of sustainable development and particularly climate change became a focal concern on the political agenda. To decouple carbon emissions from economic growth, but also for fiscal reasons, all the Nordic countries have introduced carbon-energy taxation since the early 1990ies. However, in recent years, the discussion on economic instruments in all Nordic countries has shifted from $\mathrm{CO}_{2}$ taxation towards international emissions trading in the context of the EU ETS and the Kyoto Mechanisms.

It can be concluded that all countries share the same overall policy agenda and issues:

- Energy Efficiency

- Security of supply

- Environment

These three energy policy areas can be deduced from the overall policy targets of growth, employment and welfare in all of the Nordic countries. This is in line with the policy agenda for the EU. However, the differences in availability of natural energy resources in the Nordic countries have spurred some differences in industry structure and power generation. Resulting differences in the approach and the development of energy policies can explain differences in the implementation of energy policy instruments.

\subsection{Energy policy instruments}

According to the above mentioned different energy policy developments, the Nordic countries have applied certain energy policy instruments differently. Nevertheless, the four main energy policy instruments which 
have been applied to fulfil political goals and address environmental concerns can be summarized in the categories of:

- Price based systems

- Quantity based systems and

- Standards and regulations

- Voluntary agreements

All kinds of environmental taxes or fees are "priced-based" policy instruments. Taxes increase the prices of certain goods and services, thereby decreasing the quantity demanded (in accordance with the price elasticity).

Emission trading (e.g., tradable emission allowances) or certificate schemes are considered a "quantity-based" environmental policy instrument. These schemes fix the total quantity or amount of, e.g. $\mathrm{CO}_{2}$ emitted or renewable energy generated, and let the price levels to be determined according to market forces.

In comparison, taxes fix the marginal cost for e.g. $\mathrm{CO}_{2}$ emissions abatement or renewable energy production and let quantities emitted or produced to adjust. A key insight is that taxes control the cost of abatement but leave the quantity of abatement uncertain, whereas emission trading do precisely the opposite.

In the short run (e.g. over the span of a year), it is usually argued that taxes are more efficient than emission trading in the face of cost uncertainty. However, in the long run this conclusion could easily be reversed.

Standards and regulations are "non-market based" tools. Regulations are rules or requirements enforce by law and issued by a competent authority. In the context of energy policy, standards and regulations (i.e. technological or output standards) are often used related to energy efficiency measures in building regulations or technical emission standards for vehicles.

The use of standards or regulations in regard to environmental effectiveness is only feasible if monitoring techniques exist that are capable of quantifying the limits imposed and there are sufficient resources to monitor compliance with the standards.

Voluntary agreements include environmental agreements negotiated with industry, public voluntary programs in which firms can choose to participate, and self-regulation. Such agreements are increasingly supplementing or replacing other policy instruments.

In the energy intensive industry sector of Sweden and in the Industry sector of Denmark, long-term agreements were pointed as one of the most efficient instruments to improve energy efficiency. Through negotiations between public authorities and industry, targets are set to improve industrial energy efficiency. The key characteristic of these agreements is that an industry trade association and its members commit themselves to 
a quantified target for energy efficiency improvement by a specific year relative to a reference year. The Swedish and Danish government then used this kind of agreements to justify tax exemptions from $\mathrm{CO}_{2} /$ energy taxes for energy intensive industry. Denmark has evaluated the total effect of their voluntary schemes with the industry from 1996-2000: the estimated $\mathrm{CO}_{2}$ reduction in 2005, as a result of agreements made from 1996-2000, amounted to $6.3 \%$ of total emissions and $2.7 \%$ of the energy consumption of manufacturing industry (Persson and Gudbjerg, 2005).

However, the environmental effectiveness and economic efficiency of voluntary agreements are often challenged. Although stakeholders agree to comply with a certain environmental standard, there is usually no penalty mechanism in case of non-compliance. Hence, voluntary agreements do not ensure that a certain target is met.

The different policy instruments, described above, usually address different target groups. Generally, tradable permit schemes are used in the private sector, i.e. the power and the heat supply sector. Trading is more appealing to private industry. By reducing emissions, firms can actually profit by selling their excess greenhouse gas allowances. Creating such a market for pollution could potentially drive emissions reductions below targets. This actually happened in the first trading period of the EU's Emission Trading Scheme (EU ETS), where verified emission levels had been much lower than projections and the actual allocation. Allowance price levels decreased to a level close to zero and the incentive to trade and/or reduce emissions remained very low.

In the residential- and service sector tax systems are usually preferred because transaction costs would be prohibitively high in a trading scheme.

\subsection{Tax versus trade}

A well functioning international emission trading system allows emission reductions to take place wherever abatement costs are lowest, regardless of international borders. Economic efficiency is high, since the overall costs of meeting a given reduction target (the cap) are minimized. In a perfect emission trading scheme, the environmental effectiveness of the scheme is given by the cap and the efficient allocation of resources is guaranteed by the information exchange among the trading entities via prices and the market mechanisms.

The current emission trading market (EU ETS) is not as perfect as theory dictates. Beside imperfect market information, heterogeneous rules and targets as well as uncertainty about the future, there are several other causes of imperfect trade: 
- Market power

- Transaction costs

- Unexpected firm behaviour

- Sector differences in ability to pass-through carbon costs

Market power means the ability of a single market participant (or a cartelised group of market participants) to affect either the total quantity or the prevailing price in the market. This could be the case, if the market participants hold a major share of the total allocation volume. To influence price levels, the market participant could withhold the credits from the market for achieving a higher price level or the participant could flood the market with its allowances to reduce price levels.

Unexpected firm behaviour refers very much to the market participants' psychological behaviour which does not always seem rational. Strategic interactions among rational market participants produce outcomes with respect to the preferences of those participants. But due to lack of information on the behaviour of the other market participants, outcomes can differ from intentions and expectations. ${ }^{23}$

Transaction costs are the costs implied with a credit's transaction. The existence of transaction costs influences the theoretical demand and supply curve of the market and therefore the market price. In example, the market price would not become lower than the actual level of transaction costs.

Differences in the pass-through of carbon costs may lead to competition distortion. The sectors' ability to pass-through carbon costs depends on the boundaries of the emission trading system. The system should cover all actors of the market. Carbon costs are only passed-through, if a reduction obligation applies to the total sector and all its actors. If a sector stays in global competition, carbon costs may not be passed-through by the actors with a reduction obligation, because this would influence their competitiveness in comparison to actors with no obligation.

The environmental effectiveness of an emission trading system basically depends on the definition of the cap as well as the market design. Hereby, it is important to think of the system boundaries. If an emission trading scheme is linked to other markets and imports of credits are allowed, emission reductions can take place outside the actual trading scheme. The scheme's absolute reduction target would not be reached within the defined scheme because credits could be imported. Nevertheless, in a global perspective, imports would yield environmental effectiveness and help to provide low cost abatement opportunities.

Taxation as an energy policy instrument is a second tool to spur emission abatements. The theoretical aim of this instrument is to set a tax

\footnotetext{
${ }^{23}$ This goes very much together with the general "game theory", which studies situations where multiple players make decisions in an attempt to maximize their returns.
} 
where marginal benefit equals marginal abatement costs. Hence, it should be profitable for a firm to abate carbon emissions as long as the marginal abatement cost is lower than the tax. In practice, carbon tax levels are not harmonized between countries and do not correspond to actual marginal abatement costs of $\mathrm{CO}_{2}$ emissions. It seems very difficult to benchmark the right tax level and in regard to environmental efficiency, a tax scheme does not guarantee the reach of a certain reduction target. Plus taxes can not necessarily yield more long-term certainty since tax levels are often changed.

In theory and in terms of economic effectiveness both a tax and a trade scheme set a price on carbon emissions, and may deliver the same level of increased efficiency by achieving the optimal abatement level at the minimum cost. The only difference of the two instruments is the distributional implications. The cost to the market participant is lower for a trading system. The government receives tax revenue with a carbon tax (but in case of auctioning, the government would also get revenues from a trading scheme).

\subsection{Combination of policy instruments}

In theory, key features of both tax and trading schemes could be usefully combined by allocating a defined quantity of permits and introducing a credit price guarantee at the same time. A minimum permit price (i.e. a floor price) or a maximum price (i.e. a price cap) could be guaranteed. This could for example be ensured by a market regulator buying and selling permits (much like the central bank regulating exchange rates by selling or buying currencies).

The price floor would help to pull through new technologies and would support reduction measures with low marginal abatement costs. A price cap would constrain the market, and would provide more certainty i.e. about short-run abatement costs.

\section{Tax and emission trading}

In some of the Nordic countries, the use of $\mathrm{CO}_{2}$ tax in ETS sectors has continued, even after the introduction of the EU ETS. Using the two different instruments in parallel does actually not contribute to higher global emission reductions. Instead, this rather concerns the question of burden sharing among the European countries and domestic ETS sectors. A country using both instruments at the same time would take a larger part of the EU target, whereas other countries would reduce less.

A second example of the double use of two different policy instruments is investment subsidies in addition to an electricity certificate sys- 
tem. This would not lead to more renewable electricity production but it would rather redistribute the generation mix within the certificate system.

Therefore, the simultaneous use of different policy instruments may be a tool for reaching individual, national targets, but it is usually not the most cost efficient way to reach an overall EU wide target.

Combining a trading scheme with additional national policy instruments reduces the efficiency of the system without giving additional emission reductions or additional renewable electricity production.

However, combining the two systems when approaching different target groups has been implemented by Denmark. The country has introduced an exemption of the electricity producer which are part of the ETS from $\mathrm{CO}_{2}$ taxation whereas non-ETS producers and sectors are taxed. ${ }^{24} \mathrm{In}$ this case there is hardly any direct overlap between the two systems. However, there are some major interactions between the target groups of these instruments. For instance, the group of small and medium-scale fossil energy users of the non-ETS sectors is affected directly by the tax scheme (through taxation of conventional energy use) and indirectly by the EU ETS (through higher electricity prices resulting from passing through carbon costs). Hence, this group may be charged double, depending on whether and to what extent the EU ETS will result in higher consumer prices for fossil electricity.

\section{Green electricity- and emission trading}

Regarding the parallel implementation of a green electricity scheme and an emission trading scheme (as it is in Sweden) there is overlap or interaction between the direct target groups of these to systems. Both schemes directly target electricity generators.

Although renewable energy policies should be accounted for when setting the national quota under the an emission trading scheme, a formal separation between the markets for green certificates and emission allowances is needed, i.e. green certificates cannot be converted to emission allowances (or vice versa) and, subsequently, traded among each other.

Overall, however, there seems to be no major problems or conflicts in operating the two systems at the same time. On the contrary, the operation of the instruments seems to be mutually reinforcing in the sense that obtaining the operational target of one instrument enforces the achievement of the target of the other.

\footnotetext{
${ }^{24}$ The EU Commission stated, that this might run against the "polluter pays" principle, a leading principle of the EU's environmental policy, as companies participating in the EU ETS have received most of the emission allowances for free.
} 


\subsection{Policy instruments in relation to the international market}

As a consequence of using national policy instruments in combination with the international markets, policy goals and instruments in one country influence conditions in neighbouring countries.

In the Nordic area we have in particular a common electricity market and to some degree national policy targets and instruments that are not harmonized. This means for example that ambitious renewable policy targets, e.g. the Swedish Green Electricity Certificate Scheme (Elcerth), reduced the need for investments in new generation capacity in the neighbouring countries. The cost of renewables development in Sweden is paid by Swedish electricity consumers, but the benefit in terms of lower electricity prices and improved security of supply is shared by consumers in all countries. On the other hand, ambitious renewables targets in one country can make it more costly to reach renewables targets in another country, to the extent that the policies yield lower electricity prices, i.e., higher subsidies are needed to realize targets. Quite the opposite may also be true: Nuclear phase outs within Sweden increases power prices and the need for further investments in power production throughout the market area.

In relation to the ETS, different allocation rules for newcomers in the Nordic countries, creates different investment incentives and distorts competition between the countries.

This demonstrates that Nordic cooperation in energy policy design is of high importance although there are differences in goals and the overall policy development. It is for example obvious that efficiency gains could be achieved through more harmonization and more common policies, but at the same time, as history shows, the countries have different challenges, and as such it is natural that the mix of policy instruments are different. The common market creates a mutual dependency and also presents new opportunities to solve problems in common. A common green certificate market and common rules for allocation of free emission allowances to new installations in the ETS are examples of areas where efficiency gains may be realized through common approaches.

Coordinated or common energy policies require that the underlying energy markets are well functioning. The Nordic Nord Pool electricity market is the best functioning multi national power market in the world. This gives a good foundation for common Nordic energy policies - if it can not work in the Nordic countries it will probably not work anywhere.

A few years ago Norway and Sweden almost created the first binational green electricity certificate market. The underlying political process and other policy co-operations have given the Nordic countries a lot of experiences to build on for the further process. 


\subsection{Adjustments of energy policy instruments}

"Price based" policy instruments do define a price ex-ante, in accordance to expected marginal costs. There is no certainty of the achievement of an environmental target. In Denmark, for example, the government has used fixed feed-in tariffs for wind power and decentralised CHP. The idea was to guarantee wind power producers a certain feed-in tariff so as to not be exposed to the uncertainty of the electricity market price.

As a result wind power and decentralised CHP capacities grew (especially in western Denmark). In some hours of the year total power generation exceeded actual demand plus export capacities which resulted in a wholesale market price of zero for electricity in these hours. Even though production should stop at a zero price level, due to the fixed feed-in tariff power producers were willing to continue production even at a negative market price. ${ }^{25}$ The system could not handle this situation and the framework of the support scheme had to be changed to avoid these situations.

The newly change to a price premium system in Denmark has overcome the problem. Now, especially decentralised CHP adjust their production to the market prices (market signals for need for power).

The Danish case is a good example on a necessary change from one political instrument to another in other to ensure efficiency of the total market in line with the increased amount of prioritised production. Even though the Danish feed-in tariffs for decentralised CHP where benchmarked at a very good average level with three tariff levels per day, the reality is that fluctuations in demand and production from other production facilities change from day to day and hour to hour. Therefore, when the share of prioritised production reaches a certain level (depending on the total fuel mix) it is necessary to introduce instruments that incentives the prioritised production to react to the fluctuations.

Another effect can be seen from taxation of electricity. In all Nordic countries the tax is levied on the use of electricity (cf. chapter 2.4). This has the advantage that the rate can be differentiated between different users. Because of international competition, electricity producers are exempt from taxes. From an environmental point of view, however, the negative effects of electricity are generally associated with electricity production. If taxation would be transferred to the electricity production, this will be favourable for renewable energy production. At the same time the system price of electricity would increase, thereby reducing the demand. On the contrary, subsidies are applied to promote renewable electricity production. This may contribute to lower average electricity prices and thereby increase electricity consumption.

\footnotetext{
${ }^{25}$ It is less costly to stop wind power plants for a short period (a few hours) than conventional power plants, which to a large extent make up the rest of the Danish system.
} 
Therefore, using a consumption tax system instead, renewable energy production will increase and electricity prices as well ${ }^{26}$.

\subsection{Case study on impact assessment of price policies}

Price based policy instruments has been suggested in the Nordic countries as an instrument to reduce electricity consumption. An increase in the price of electricity is assumed to reduce electricity consumption. However, the effectiveness of using pricing policy is highly dependent on the consumer price elasticity of electricity demand. If the consumers' sensitivity to variations in the price of electricity is high, i.e. if the price elasticity is high, an increase in the consumer price of electricity causes a considerable reduction in the electricity consumption. If the price elasticity is low, the effect of the introduction of a policy-induced price increase will be smaller.

From an environmental point of view, a reduction in electricity consumption is desirable since it is assumed to reduce $\mathrm{CO}_{2}$ emissions. However, to what extent a reduction in the electricity consumption reduces the emissions of $\mathrm{CO}_{2}$ depends on how the marginal electricity is generated. If the marginal electricity is generated by, for example, hydroelectric power plants, a reduction in electricity consumption will not have any effect on the emissions of $\mathrm{CO}_{2}$. However, if the marginal electricity is generated by, for example, coal power plants, a reduction in the consumption of electricity will certainly reduce the emissions of $\mathrm{CO}_{2}$.

In this section, we will illustrate the effects of using pricing policy to reduce $\mathrm{CO}_{2}$ emissions. However, predicting the consequences of the introduction of a pricing policy is complicated. Our results should thus be regarded as very rough estimations of the expected effects. Nevertheless, our estimates can give us some idea of the effectiveness of using pricing policy and illustrate how the magnitude of the price increase, the price elasticity of electricity demand and the type of marginal electricity together impact the emissions of $\mathrm{CO}_{2}$.

Within the Kyoto agreement and since the introduction of the European Union Emissions Trading Scheme (EU ETS) in 2005, there is a common upper limit for the European emissions of $\mathrm{CO}_{2}$. Therefore, reduced $\mathrm{CO}_{2}$ emissions in the Nordic region yield increased emissions in other parts of Europe. It can thus be argued that using pricing policy in the Nordic region to reduce the emissions of $\mathrm{CO}_{2}$ from sectors covered by the EU ETS does not have any effect at all on the environment. However, it can still be of great interest to evaluate the potential for reduction of $\mathrm{CO}_{2}$ emissions through pricing policy in the Nordic region with focus on

\footnotetext{
${ }^{26}$ Nordic Council of Ministers (2007), The impact of renewables and energy efficiency on GHG emissions.
} 
the idea of enforcing "cost efficient" reductions. The ETS enhances people to reduce emissions until the nationally defined caps. Everything what is reduced additionally, will be then bought by someone else (maybe not in the Nordic countries), which means, the reduction has been happen still most cost efficient, even though there has been no additional environmental effect. But the mechanism also works the other way around, if the Nordic countries cannot reach their target, they will get it from somewhere else, so someone needs to reduce more. However, this is only valid for the ETS sectors.

In order to estimate the effects that the introduction of a pricing policy will have on electricity consumption, and thereby on $\mathrm{CO}_{2}$ emissions, we need to make assumptions about the magnitude of the price increase, the price elasticity of electricity demand and the marginal electricity production. We assume that a common Nordic policy measure is implemented that increases the price of electricity on Nordpool by $€ 15 / \mathrm{MWh}$. Furthermore, we assume that this price increase yields a $10 \%$ increase in the enduser price of electricity in all of the Nordic countries. Note that this enduser price increase also can be achieved in other ways, for example through an increase in the tax on electricity consumption.

On the basis of the literature on electricity demand that was summarized in Table 7 (Section 3.2), we assume that the short-run price elasticity in all of the Nordic countries, and for all consumer segments amounts to -0.35 and that the corresponding long-run elasticity is -0.75 . As thoroughly discussed in previous sections, modelling electricity demand is very complex. The assumed price elasticities should therefore primarily be regarded as rough estimates of the true elasticities. Furthermore, our own econometric analysis (Section 3.3), that was conducted in order to compare the price elasticities between the Nordic countries, suggests that the Norwegian consumers are more price sensitive than the consumers in the other Nordic countries. It is thus possible that the price elasticities used in the following analysis underestimate the price elasticity on the Norwegian market, whereas they might overestimate the true price elasticities in the other countries. However, since we have not been able to draw definitive conclusions about the differences in price elasticities between the Nordic countries, we conduct the environmental impact analysis using common price elasticities for all of the Nordic countries.

Studies show that in the majority of time, the marginal electricity on the Nordic market is generated by coal power plants (ECON, 2002; Elforsk, 2006). Therefore, we will conduct the environmental impact analysis assuming that in the short-run, the marginal electricity comes from a coal power plant. In the long-run, the electricity generation system will develop, and it is difficult to predict how the marginal electricity will be generated. Furthermore, in some cases it is plausible that the policy measure that is examined would make the electricity generation system develop in a certain way, which makes it even more difficult to predict 
how the future marginal electricity will be generated. However, in this analysis, we assume that the marginal electricity in the long-run is generated by coal power plants $50 \%$ of the time and by natural gas power plants $50 \%$ of the time. Modern coal and natural gas power plants produce approximately 750 and 350 tons of $\mathrm{CO}_{2} / \mathrm{GWh}$ respectively. Thus, in the short-run we assume that a reduction of the electricity consumption by $1 \mathrm{GWh}$ reduces $\mathrm{CO}_{2}$ emissions by 750 tons, whereas a reduction by 1 GWh in a more distant future is assumed to reduce $\mathrm{CO}_{2}$ emissions by 550 tons. In Iceland, the marginal electricity is generated by hydro or geothermal power plants, both of which do not emit $\mathrm{CO}_{2}$. Therefore, we do not include Iceland in the following environmental impact analysis.

For each of the four countries, we use data on electricity consumption from 2005 as a starting point for the analysis. We conduct the analysis for two different scenarios; one where the new policy affects only the household sector and one where the new policy affects all sectors. In the latter case, we use the same assumptions about the price elasticities as in the analysis of the household sector. This is a very strong simplification since the empirical studies behind the price elasticities assumptions all focus on the household sector. However, as stated above, the estimated impact on $\mathrm{CO}_{2}$ emissions should only be regarded as a rough estimate.

In 2005, household electricity consumption in Sweden amounted to 41.6 TWh. Assuming that the introduction of a pricing policy results in a $10 \%$ increase of the end-user price and that the short-run price elasticity is -0.35 , the new policy leads to a reduction in household electricity consumption of 1,456 GWh. Assuming that the marginal electricity in the short-run is generated by a coal power plant emitting 750 tons $\mathrm{CO}_{2} / \mathrm{GWh}$, the estimated reduction in household electricity consumption results in a reduction in $\mathrm{CO}_{2}$ emissions of slightly more than 1 million tons. In other words, given the above stated assumptions, a $10 \%$ price increase in the price of electricity that Swedish households face, reduce $\mathrm{CO}_{2}$ emissions by approximately 1 million tons. This is illustrated in the upper left corner of Table 9 for Sweden. In the long-run assuming that the price elasticity is -0.75 and that the marginal electricity is generated by equal proportions of coal- and gas power plants, the estimated reduction in $\mathrm{CO}_{2}$ emissions amounts to approximately 1.7 million tons.

Table 9 Reduction in $\mathrm{CO}_{2}$ emissions (million tons) resulting from a $10 \%$ increase in the end-user price of electricity. Source: own estimations

\begin{tabular}{lcccc}
\hline & \multicolumn{2}{c}{ Household sector } & \multicolumn{2}{c}{ All sectors } \\
& Short-run & Long-run & Short-run & Long-run \\
\hline Sweden & 1.09 & 1.72 & 3.50 & 5.50 \\
Norway & 0.92 & 1.45 & 2.90 & 4.56 \\
Denmark & 0.26 & 0.40 & 0.88 & 1.38 \\
Finland & 0.54 & 0.85 & 2.15 & 3.37 \\
\hline Total & 2.81 & 4.42 & 9.43 & 14.81 \\
\hline
\end{tabular}


The results from the corresponding calculations for all of the countries are presented in the Table 9 . In the table we also present the results from the calculations when assuming that the new policy increases the price of electricity in all sectors by $10 \%$ (The two columns to the right in the table).

Since we assume that the magnitude of the price increase, the price elasticity of electricity demand and the marginal electricity is the same in all four countries, the initial level of electricity consumption is the determining factor for the differences in size of the reduction in $\mathrm{CO}_{2}$ emissions between the Nordic countries. Consequently, since electricity consumption in Sweden exceeds consumption in any of the other Nordic countries, the estimated reduction in $\mathrm{CO}_{2}$ emissions is largest in Sweden. Naturally, this applies to both the short- and the long-run estimates.

The total long-run reduction in $\mathrm{CO}_{2}$ emissions in the Nordic region resulting from a $10 \%$ increase in the household electricity price amounts to approximately 4.4 million tons, which corresponds to about $2 \%$ of the total $\mathrm{CO}_{2}$ emissions in the Nordic region. Furthermore, the total long-run reduction in $\mathrm{CO}_{2}$ emissions resulting from a $10 \%$ increase in the electricity price for all electricity consumers amounts to approximately 15 million tons, which corresponds to about $7 \%$ of the of the total $\mathrm{CO}_{2}$ emissions in the Nordic region. Given the above stated assumptions, it is thus fully possible to reduce the emissions of $\mathrm{CO}_{2}$ in the Nordic region through pricing policy.

\subsection{Conclusions}

Recently, energy policy targets of the Nordic countries has emphasised environmental goals, particularly the reduction of $\mathrm{CO}_{2}$ emissions, as well as the support of renewable energy sources.

The latter has been approached by the countries via the implementation of feed-in tariffs, fiscal incentives and/or a green electricity certificate scheme. In regard to economic and environmental effectiveness a green electricity trading system should be preferred to the other systems. The "marked based" instrument ensures a cost effective increase of renewable electricity production, increases general price levels and demand respond would result in a decrease of overall consumption. At the same time, it would contribute to the overall target of $\mathrm{CO}_{2}$ emission reductions.

Further reduction in $\mathrm{CO}_{2}$ emissions is enhanced by implementation of additional energy policy instruments. Hereby, emission trading is considered as a very environmentally effective instrument (if caps are defined accordingly). But at the meantime, it only targets certain private industry sectors. With respect to economic efficiency it would be desirable to include as many sectors as possible in the ETS, as long as they entail 
abatement potentials, but administrative costs argue against this in regard to some non-industry sectors.

Therefore the service- and residential sector is usually approached by other instruments - in the Nordic countries by consumer taxation. Carbon- as well as electricity taxes are levied on consumption, which result in demand responses. The level of the tax rate itself defines the environmental effectiveness of the instrument. Hence, it is not ensured that a reduction target will be met, only by introducing a tax.

All the Nordic countries apply different policy instruments simultaneously. This practice may lead to negative and unexpected effects, particularly if the instruments target the same group of market participants.

Instruments and their effects may overlap in certain conditions. Subsidy schemes on renewable energy sources usually target non-fossil energy production. Energy taxation schemes are applied on the energy consumer side. And emission trading is introducing a carbon cost on fossil fuel energy production. By applying an additional cost on fossil fuel production, emission trading enhances fuel switching to less carbon intensive fuel sources and therefore reduces $\mathrm{CO}_{2}$ emission levels. An additional support scheme for renewable energy sources is also leading to a higher environmental effective energy production. Hereby, the actual overlap of these instruments is rather small. And low $\mathrm{CO}_{2}$ prices, do not sufficiently add to an increase in renewable energy investments. In comparison, the overlap between the two instruments, in case of high $\mathrm{CO}_{2}$ prices, seems stronger. High $\mathrm{CO}_{2}$ prices would result in a higher incentive to invest into renewable energy production which could supersede an additional support scheme of renewables.

Therefore, under certain framework conditions, applying several instruments aiming for the same goal could enhance inefficiencies within the instruments by not contributing to higher environmental effectiveness. However, one has to consider the system's boundaries. There are differences in the effectiveness of an instrument in a global or a national perspective. And since energy markets are very much linked internationally and especially in the Nordic region, the cooperation within Nordic energy policy is important, not least because long term goals of the Nordic countries are very similar.

Demand for energy in the Nordic countries is not very short-run price elastic. Hence, in a short term perspective, emission reductions will take place at the production side rather than on the demand side. But assuming that policy instruments are applied as long-term signals, it is rather useful to look at the long term effects. It is reasonable to assume that the long term elasticity is higher than the short-term one. Demand changes are in other words expected to contribute to emission reductions. But long-term adjustments in demand will probably only come about if consumers expect prices to be permanently higher. 
Generally, the introduction of policy instruments like the ETS and energy taxes will however result in an overall increase in energy prices and prices of energy-intensive goods in the production. The price increase on goods happens according to the rate of pass through of the carbon costs.

Depending on the fuel production mix, effects by demand respond differ. Any energy efficiency measures, in form of energy savings will lead to emission reductions. But it has been analysed that savings in electricity have resulted in higher $\mathrm{CO}_{2}$ emission reductions than savings in heat consumption. This is because the heat production is generally less $\mathrm{CO}_{2}$ intensive (based on CHP and/or higher share of renewable energy sources). And since energy savings generally respond on price levels, an increase in electricity prices is more meaningful than an increase in heat prices due to the higher $\mathrm{CO}_{2}$ intensity of electricity production.

In regard to the demand respond of the industrial sectors (TemaNord 2006:528) analysis showed that for the other fuels than electricity (i.e. oil, coal and waste energy) the own price elasticity is much higher than for electricity (Table 6). This could indicate that carbon-energy taxes will induce considerable reduction in energy consumptions if taxes are exposed on these fuels. Therefore, $\mathrm{CO}_{2}$ taxes and other price-based policy instruments may be very effective in order to reach environmental targets. However, due to the low price elasticity for electricity consumption in household, price-based policy instruments are more effective for the other fuels and sectors.

The choice and implementation of specific policy instruments depends to a considerable degree on the national context and its national policy history. Strategies for pollution control and renewable energy support reflect deeply-rooted traditions of government intervention, and in particular, of the relationship between government and industry. Each country's regulatory style is thus a function of its political heritage. It requires comprehensive knowledge of constitutional, administrative, historical and cultural institutions to understand the opportunities and limitations arising from a particular policy style. 


\section{References}

Andersson, B. (1997): "Electricity

Demand - A Study of the Swedish Residential Sector" in Andersson, B. Essays on the Swedish Electricity market, PhD thesis Stockholm School of Economics.

Bohi, D and Zimmerman, M. B. (1984): "An Update on Econometric Studies of Energy Demand Behaviour", Annual Review of Energy vol. 9 105-154.

Brännlund, R., Ghalwash, T. and Nordström, J. (2007): “Increased Energy Efficiency and the Rebound Effect: Effects on consumption and emissions”, Energy Economics 29 1-17.

Dahl, C. (1993): “A Survey of Energy Demand Elasticities in Support of the Development of the NEMS”, U.S. Department of Energy, Washington DC.

Damsgaard, N. (2003): "Residential Electricity Demand - Effects of Behaviour, Attitudes and Interest" in Damsgard, N. Deregulation and Regu-lation of Electricity Markets, $\mathrm{PhD}$ thesis Stockholm School of Economics.

Directive 2001/77/EC, EU. The Renewable Energy Directive.

Elforsk (2006): Marginalel och miljövärdering av el, Elforsk rapport 06:52.

ECON (2002): Marginalel och produktion och CO2-utsläpp i Sverige, ECON rapport 19/02.

Energistyrelsen, En visionær dansk energipolitik 2025, januar 2007.

ENERGY IN ICELAND, National Energy Authority, Iceland, 2004. EU COM(2006) 848 final.

EU COM(2007)1, One European Energy Policy, March 07.

Halvorsen, B. and Larsen, B. (2001): "The Flexibility of Household Electricity Demand Over Time”, Resource and Energy Economics 23 1-18.

Halvorsen, B., Larsen, B. and Nesbakken, R. (2001): "Hvordan utnytte resulater fra mikrookonometriske analyser av husholdningenes energi- forbrok i makromodeller? En diskusjon av teoretisk og empirisk litteratur om aggregering”, Statistics Norway. Johnsen, T. A. (2001): "Demand, generation and price in the Norwegian market for electric power", Energy Economics 23 227-251.

Leth-Petersen, S., Halvorsen B., Larsen B. and Nesbakken, R. (2003): "Residential Demand for Heating in Liberalized Electricity Markets: Evidence from Denmark and Norway" in LethPetersen Empirical Stud-ies of Micro Data on Residential Energy Demand, $\mathrm{PhD}$ thesis Copenha-gen University.

Nesbakken, R. (1999): "Price Sensitivity of Residential Energy Consumption in Norway", Energy Economics 21 493-515.

Nordel (2005): Nordel Annual Report 2005.

Norden, Nordic Council of Ministers (2007), The impact of renewables and energy efficiency on GHG emissions.

Norden, Nordic Council of Ministers (2006), Decoupling of CO2 Emission from Energy Intensive Industries. TemaNord 2006:528.

The Nordic Competition Authorities (2003): “A Powerful Competition Policy - towards a more coherent competition policy in the Nordic market for electricity power”. Copenhagen, Oslo, Stockholm.

NordREG, Supplier switching in the Nordic countries. Nordic Energy Regulators, 2005.

NVE, Vindkraft I Norge - status januar 2005.

Persson, A. and E. Gudbjerg, E. (2005). Do voluntary agreements deliver? Experiences from Energy Management Systems and schemes, In Proceedings of the European Council for Energy Efficient Economy (ECEEE) summer study. Stockholm: ECEEE.

Taylor, L. (1975): "The Demand for Electricity: A Survey.” Bell Journal of Economics 6(1) 74-110. 


\section{Danish summary}

Hvorfor er energiproduktionen og - forbruget forskelligt i de nordiske lande? Og kan man via finansielle og politiske reguleringsinstrumenter påvirke energiforbruget og dermed også miljøeffekten af dette?

Forekomsten af energiressourcer er vidt forskellig i de nordiske lande. Norge og Danmark har egne petroleumsressourcer. Mens Danmark bruger det meste af deres produceret naturgas som indlandsforbrug, så er det kun $1 \%$ af det norske slutenergiforbrug, som er baseret på naturgas. Dette svarer i størrelsesorden til det svenske forbrug af naturgas, selvom Sverige ikke har naturgasressourcer. Norge bruger dog en del naturgas i forbindelse med udvinding af olie.

Også udbredelsen af fjernvarme og kraft-varmeproduktion er meget forskellig mellem de nordiske lande. Danmark har den største andel af fjernvarme, som er baseret på kraft-varmeproduktion.

Fundamentet for det nuværende brændselsmiks er historisk bestemt. Naturlig forekomst af forskellige energiressourcer og politiske prioriteringer har formet energisektorerne gennem det sidste århundrede. Især udviklingen af netafhængige energityper har været drevet af central planlægning og har været meget påvirket af politiske prioriteter. Denne gruppe af energityper inkluderer elektricitet, fjernvarme og naturgas. Eksempel på dette er den danske udbygning af naturgasnettet og fjernvarmeplanlægningen, hvor der vise steder blev indført obligatorisk tilslutning til nettene.

Politisk prioritet har især været givet til vedvarende energi. Specielt inden for elsektoren har små-skala vedvarende energi fået særlig prioritetsstatus, mens den konventionelle elproduktionsside er blevet liberaliseret.

Store forekomster af geotermisk energi i Island og vandkraft i Norge, Sverige og Island gjorde det oplagt at basere deres energiforsyning på disse ressourcer i det omfang det var muligt. Dette har især påvirket, at brændselsmikset i elforsyningen er meget forskellig mellem de nordiske lande. Kul, naturgas og vindkraft dominerer den danske elproduktion, mens den norske elproduktion næsten udelukkende er baseret på vandkraft. Sverige har ca. $50 \%$ vandkraft og $50 \%$ atomkraft, mens den Finske elproduktion er baseret på en blanding af de forskellige brændsler. Endelig baseres den islandske elproduktion hovedsagelig på vand- og geotermisk kraft.

Den store andel af fossile brændsler i elproduktionen i Danmark og Finland gør, at miljøpåvirkningen i form af drivhusgasser fra elsektoren er langt større i disse lande end i de andre nordiske lande. 
Opvarmning af huse sker via forskellige energityper i Norden. I Island er det især geotermisk energi, elektricitet i Norge og fjernvarme dominerer i Danmark.

Skift mellem brændsler er meget afhængig af mulighederne for at skifte. Studier af de nordiske husholdninger viser, at Danske husholdninger stort set ikke substituerer mellem forskellige energiformer for opvarmning af husene, mens Norske husstande gør. Denne forskel mellem Norge og Danmark stammer fra forskellene i de institutionelle set-ups i de to lande. Danmark og Norge er meget ens i forhold til kultur og organisering. Men der er store forskelle på adgang til energiressourcer, regulering af de forskellige energimarkeder og industristrukturen. Norsk energipolitik sætter få restriktioner på husholdningerne, hvorfor de tit har flere kilder til opvarmning.

Priserne på fjernvarme er ofte regulerede og følger niveauet på olie, elektricitet eller anden alternativ opvarmningsenergi. Tilpasning af fjernvarmepriserne ske generelt kun få gange om året.

\section{Energiforbruget}

De nordiske lande har nogle af EU's højeste energiafgiftsniveauer. Alligevel er energiforbruget pr. indbygger generelt højere i de nordiske lande end i resten af EU. Kun Danmark har en national energiintensivitet som ligger tæt på EU’s gennemsnitsniveau.

Især elforbruget pr. indbygger er meget forskelligt mellem de nordiske lande. Det norske elforbrug er næsten 5 gange så højt pr. indbygger som i Danmark. Dette skyldes især at elektrisk opvarmning er udbredt i Norge, og at Norge har flere energiintensive industrier end Danmark.

Tilsvarende er niveauet for forbrugspriserne for elektricitet til husholdninger meget forskellige, hvor prisniveauet i Danmark er næsten tre gange så højt som i Norge (Table 10).

Tabel 10: Forbrugerprisniveauer for elektricitet til husholdninger i de Nordiske lande og deres relative andel af moms og energiafgifter.

\begin{tabular}{lcc}
\hline & Forbrugerpriser cent $€ /$ kWh & Andel af moms og afgift \\
\hline Danmark & 24 & $57 \%$ \\
Sverige & 13 & $42 \%$ \\
Finland & 12 & $24 \%$ \\
Norge & 8,5 & $33 \%$ \\
\hline
\end{tabular}

De store niveauforskelle i forbrugspriserne på elektricitet skyldes især afgifts- og momsniveauet i de forskellige lande, men også bidrag til prioriteret produktion, systemydelser og net-afgift. I Danmark er det kun ca. $15 \%$ af forbrugsprisen som stammer fra engrosprisen for el.

Ser man på udviklingen af forbrugerpriserne på elektricitet, så kan man sammenligne de nordiske priser ved at sammenligne det harmonise- 
ret indeks for forbrugspriser (HIPC). HIPC for elektricitet med indeks-år 1996 er vist i Figur 35.

Igen skiller Norge sig ud i forhold til de andre nordiske lande. Forbrugspriserne i Norge er steget med $70 \%$ over 10 år, mens den kun er steget med 5\% i Finland. Desuden har de norske forbrugspriser været meget mere volatile end forbrugspriserne i de andre nordiske lande.

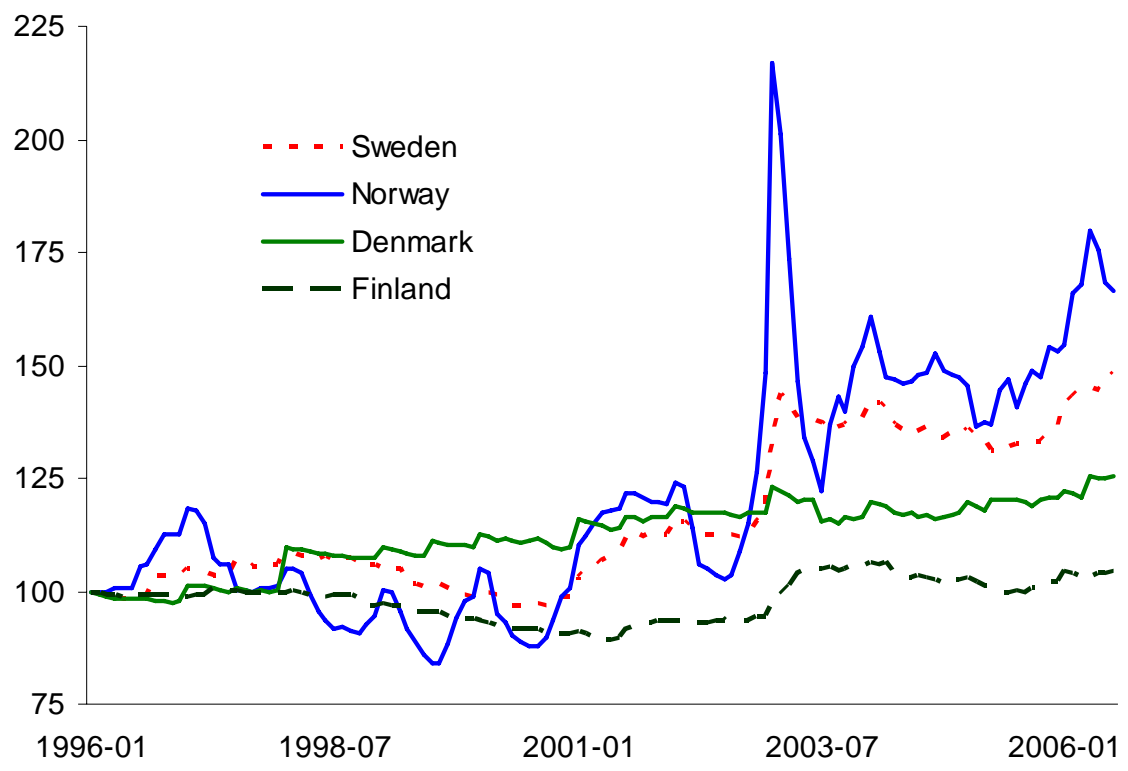

Figur 35: Udviklingen i HIPC indekset for elektricitet over tid.

For at finde ud af hvordan forbrugerne reagere på ændringer i forbrugspriserne, udførtes en økonometrisk analyse i denne rapport. Analysen viste, at det på kort sigt især er de norske husholdninger, som reagerede på høje elpriser ved at nedsætte deres forbrug. De svenske husholdninger reagerede med en tidsforsinkelse på ca. 6 måneder. Hvorimod, det ikke var muligt at påvise generelt, at husholdningerne i Finland eller Danmark reagerede på ændringer i forbrugspriserne på elektricitet. Man kan dog antage, at forbrugerne på lang sigt vil reagere på ændringer i prisniveauet.

Virkningen af energipolitiker, som påvirker forbrugspriserne på elektricitet til husholdninger, kan derfor varierer meget mellem de nordiske lande.

\section{Energiafgifter og miljøet}

Nationale energi- og miljøpolitiker i et nordisk land kan påvirke opnåelse af energi- og miljøpolitiske mål i de andre nordiske lande. Derfor er det vigtigt, at energi- og miljøpolitikerner koordineres - ikke nødvendigvis via fælles energipolitikker, men nok til at der tages højde for gensidige påvirkninger mellem landene og under hensyn til landenes forskellige miljø- og energipolitiske målsætninger. 
Koordinering eller fælles energipolitikker kræver, at de underliggende energimarkeder virker perfekte. Det nordiske elmarked (Nord Pool området) er det bedst fungerende flernationale elmarked i verden. Dette giver et godt fundament til øget politisk effektivitet ved en mulig implementering af fælles nordiske energipolitikker - hvis det ikke kan fungere i de nordiske lande, så kan det sikkert ikke fungere noget steds i verden.

De nordiske lande har anvendt energirelaterede afgifter og skatter for årtier. Den bagvedliggende grund har hovedsagelig været økonomiske, men afgifter og skatter har haft en stor betydning for energiforbruget og brændselsvalget og dermed også for $\mathrm{CO}_{2}$-emissionerne i de nordiske lande. Studier viser, at politiske virkemidler som det europæiske $\mathrm{CO}_{2}$-kvotesystem (ETS), støtte til vedvarende energi og energiskatter alle har haft en signifikant rolle som politisk instrument til at reducere udslipsniveauet af drivhusgasser.

Påvirkning af drivhusgasniveauet via politiske virkemidler på elprisen er begrænsede på grund af den relative lille priselasticitet, der kan observeres i forbrugspriserne. Rapportens økonometriske analyse indikerer, at påvirkninger af elprisen på kort sigt især vil påvirke elforbruget i Norge, thi det et det land som estimeres til at have den højeste priselasticitet.

På langt sigt er det sandsynlig, at forbrugerne i de nordiske lande generelt vil tilpasse deres bestand af elektriske apparater og brug af energieffektive installationer, og dermed vil man kunne påvirke elforbruget og drivhusgasudslippet fra elsektoren.

I rapporten laves en lille indikativ partielanalyse af en $10 \%$ øgning af forbrugspriserne for elektricitet i Norden. Et meget løst bud er, at det vil medføre en reduktion på 9 millioner tons $\mathrm{CO}_{2}$ på kort sigt i elsektoren og en reduktion på op til 14 millioner tons $\mathrm{CO}_{2}$ på langt sigt. Disse tal skal dog tages med et gram salt, idet analysen er lavet med simple antagelser.

Et tidligere studie (TemaNord 2006:528) har lavet tilsvarende analyser på ti industrisektorer i Norden, og med forskellige energi-brændsler. De finder, at priselasticiteten er meget højere for olie, kul og andre energityper end elektricitet. Dette kunne indikere, at energiafgifter vil medføre en større drivhusgasreduktion, hvis de anvendes på disse brændsler i stedet for på elektricitet. Energiafgifter lægger beskatningen direkte på energityperne og påvirker dermed dem som står for drivhusgasudslippene. Dermed er man sikker på en klimaeffekt end ved elafgifter.

Elektricitet produceres via mange forskellige brændsler og en generel ændring af elektricitetsforbruget vil derfor kun medføre CO2-reduktioner, hvis de marginale værker, som nedsætter deres produktion, er værker med høje emissioner. Hvis ikke fås en lille klimaeffekt af elafgiften. 


\section{Appendices}

\section{Energy taxes applicable to gas and electricity in the Nordic countries}

Source: Deloitte, European Energy Taxes ${ }^{27}$

\section{Denmark}

\begin{tabular}{|c|c|c|}
\hline & Electricity & Gas \\
\hline \multirow{2}{*}{$\begin{array}{l}\text { Indirect Tax (other } \\
\text { than VAT) }\end{array}$} & Excise duty of electricity & Excise duty on natural gas \\
\hline & Elektrizitätsabgabe) & (Erdgasabgabe) \\
\hline Chargeable event & $\begin{array}{l}\text { Supply or usage of energy. Refund is } \\
\text { possible under specified conditions }\end{array}$ & $\begin{array}{l}\text { Supply or usage of gas. Refund is } \\
\text { possible under specified conditions }\end{array}$ \\
\hline Taxable basis & Amount of electricity supplied or used & Amount of gas supplied or used \\
\hline Normal Tariff & $€ 0.075 / \mathrm{kWh}$ & $€ 0.307 / \mathrm{m}^{3}$ \\
\hline \multirow[t]{2}{*}{ Exemptions } & $\begin{array}{l}\text { Electricity used for the production and } \\
\text { transport of electricity, gas or mineral oil. }\end{array}$ & $\begin{array}{l}\text { Gas used for production, transport or } \\
\text { storage of gas }\end{array}$ \\
\hline & $\begin{array}{l}\text { Production facilities with a capacity less } \\
\text { than } 150 \mathrm{~kW} \text { etc. }\end{array}$ & Gas used for processing of mineral oil \\
\hline $\begin{array}{l}\text { Suspension } \\
\text { regime }\end{array}$ & Not applicable & Not applicable \\
\hline General Liability & Supplier, producer or net provider & Supplier, net provider or user of gas \\
\hline $\begin{array}{l}\text { Liability in case of } \\
\text { delivery by a } \\
\text { foreign company }\end{array}$ & Documentation by invoice & Documentation by invoice \\
\hline Penalties & $\begin{array}{l}2 \% \text { late payment, } 10 \% \text { late filing, } 200 \% \\
\text { non compliance (worst case) }\end{array}$ & $\begin{array}{l}2 \% \text { late payment, } 10 \% \text { late filing, } \\
200 \% \text { non compliance (worst case) }\end{array}$ \\
\hline
\end{tabular}

Table 11: Energy taxes applicable to gas and electricity in Denmark

\footnotetext{
${ }^{27}$ http://www.deloitte.com/dtt/section node/0,1042,sid\%253D20779,00.html
} 
Norway

\begin{tabular}{|c|c|c|}
\hline & Electricity & Gas \\
\hline \multirow[t]{2}{*}{$\begin{array}{l}\text { Indirect Tax (other than } \\
\text { VAT) }\end{array}$} & $\begin{array}{l}\text { Tax on Consumer Tax on electri- } \\
\text { cal power (El-avgift). }\end{array}$ & $\begin{array}{l}\text { A CO2 fee is paid at the extraction } \\
\text { point for use of natural gas. }\end{array}$ \\
\hline & $\begin{array}{l}\text { A new taxation system for the } \\
\text { industry with respect to the taxes } \\
n \text { electricity will come into force } \\
\text { from } 1 \text { July } 2004\end{array}$ & $\begin{array}{l}\text { It is expected that a consumption tax } \\
\text { for natural gas for heating will be } \\
\text { introduced in } 2007 \text {. }\end{array}$ \\
\hline Chargeable event & Supply of electricity & \\
\hline Taxable basis & Amount of electricity supplied & \\
\hline Normal Tariffs & NOK 0.0967/kWh & \\
\hline \multirow[t]{2}{*}{ Exemptions } & $\begin{array}{l}\text { Electricity delivered abroad, } \\
\text { electricity used in industry in } \\
\text { general is exempted until } 30 \text { June } \\
2004 \text {. }\end{array}$ & \\
\hline & $\begin{array}{l}\text { All consumers/industry in the } \\
\text { county of Finnmark and some } \\
\text { municipals in the county of Troms } \\
\text { (Northern part of Norway) }\end{array}$ & \\
\hline Suspension regime & No & \\
\hline General Liability & $\begin{array}{l}\text { Distributor or producer (own } \\
\text { consumption) }\end{array}$ & \\
\hline $\begin{array}{l}\text { Liability in case of } \\
\text { delivery by a foreign } \\
\text { company }\end{array}$ & No & \\
\hline Penalties & $\begin{array}{l}\text { Up to } 200 \% \text { or up to } 400 \% \text { (reit- } \\
\text { eration) of the tax due }\end{array}$ & \\
\hline
\end{tabular}

Table 12: Energy taxes applicable to gas and electricity in Norway 
Finland

\begin{tabular}{|c|c|c|}
\hline & Electricity & Gas \\
\hline \multirow{2}{*}{$\begin{array}{l}\text { Indirect Tax (other } \\
\text { than VAT) }\end{array}$} & 1. Excise duty on electricity & 1. Excise duty on gas \\
\hline & 2. Strategic stockpile fee & 2. Strategic stockpile fee \\
\hline Chargeable event & $\begin{array}{l}\text { Release from network into consump- } \\
\text { tion (output-taxation) or own con- } \\
\text { sumption by the producer }\end{array}$ & Importation or consumption \\
\hline Taxable basis & Amount of electricity released & Amount of gas \\
\hline \multirow[t]{5}{*}{ Normal Tariffs } & Excise duty: & Excise duty: $€ 0.0182 / \mathrm{Nm}^{3}$ \\
\hline & & Stockpile fee: $€ 0.0008 / \mathrm{Nm}^{3}$ \\
\hline & $\begin{array}{l}\text { Category } 1 \text { (households and ser- } \\
\text { vices): } € 0.0073 / \mathrm{kWh}\end{array}$ & \\
\hline & $\begin{array}{l}\text { Category } 2 \text { (mining industry, industrial } \\
\text { manufacturing): } € 0.0044 / \mathrm{kWh}\end{array}$ & \\
\hline & Stockpile fee $€ 0.00013 / \mathrm{kWh}$ & \\
\hline \multirow[t]{2}{*}{ Exemptions } & $\begin{array}{l}\text { Electricity produced by very nominal } \\
\text { maximum capacity, possible refunds. }\end{array}$ & $\begin{array}{l}\text { Use as raw material or auxiliary } \\
\text { substance in industrial production, use } \\
\text { in the production of electricity }\end{array}$ \\
\hline & $\begin{array}{l}\text { If excise duties paid by an enterprise } \\
\text { during its accounting period exceed } \\
3.7 \% \text { of the added value produced by } \\
\text { the enterprise, it is entitled to a partial } \\
\text { refund. This refund amounts to } 85 \\
\% \% \text { of the excise duties exceeding } \\
\text { the above mentioned percentage. } \\
\text { Only that part of the refund which } \\
\text { exceeds } € 50.000 \text { is paid. }\end{array}$ & $\begin{array}{l}\text { If excise duties paid by an enterprise } \\
\text { during its accounting period exceed } \\
3.7 \% \text { of the added value produced by } \\
\text { the enterprise, it is entitled to a partial } \\
\text { refund. This refund amounts to } 85 \% \text { of } \\
\text { the excise duties exceeding the above } \\
\text { mentioned percentage. Only that part } \\
\text { of the refund which exceeds } € 50.000 \\
\text { is paid. }\end{array}$ \\
\hline Suspension regime & No & No \\
\hline General Liability & Network owner or producer & Importer (or user) \\
\hline $\begin{array}{l}\text { Liability in case of } \\
\text { delivery by a foreign } \\
\text { company }\end{array}$ & Yes & Yes \\
\hline Penalties & Depends on the irregularity & Depends on the irregularity \\
\hline
\end{tabular}

Table 13: Energy taxes applicable to gas and electricity in Finland 
Sweden

\begin{tabular}{|c|c|c|}
\hline & Electricity & Gas \\
\hline \multirow{2}{*}{$\begin{array}{l}\text { Indirect Tax (other } \\
\text { than VAT) }\end{array}$} & Energy tax on electric power & 1. Energy tax \\
\hline & & 2. Carbon dioxide tax \\
\hline Chargeable event & $\begin{array}{l}\text { Supply (or in some cases own con- } \\
\text { sumption) }\end{array}$ & $\begin{array}{l}\text { Among others the supply, import or } \\
\text { consumption by a registered person }\end{array}$ \\
\hline Taxable basis & Energy (kWh) & Volume \\
\hline \multirow[t]{2}{*}{ Normal Tariffs } & SEK 0.241/kWh & 1. SEK $237 / 1,000 \mathrm{~m}^{3}$ \\
\hline & & 2. SEK $1,946 / / 1,000 \mathrm{~m}^{3}$ \\
\hline Exemptions & $\begin{array}{l}\text { Among others use in industrial manu- } \\
\text { facturing, greenhouse cultivation, } \\
\text { electric power generated by certain } \\
\text { small producers }\end{array}$ & $\begin{array}{l}\text { Exemptions are applicable in some } \\
\text { cases }\end{array}$ \\
\hline Suspension regime & Yes & Yes \\
\hline General Liability & $\begin{array}{l}\text { Producer, supplier (or in some cases } \\
\text { the purchaser) }\end{array}$ & $\begin{array}{l}\text { Producer, importer or trader/user on a } \\
\text { large scale }\end{array}$ \\
\hline $\begin{array}{l}\text { Liability in case of } \\
\text { delivery by a foreign } \\
\text { company }\end{array}$ & $\begin{array}{l}\text { In case of delivery from a foreign } \\
\text { company in or out EU liability occurs }\end{array}$ & $\begin{array}{l}\text { In case of delivery from a foreign } \\
\text { company in or out EU liability occurs }\end{array}$ \\
\hline Penalties & Additional tax of $5 \%$ or $20 \%$ & Additional tax of $5 \%$ or $20 \%$ \\
\hline
\end{tabular}

Table 14: Energy taxes applicable to gas and electricity in Sweden 


\section{Nordic countries' energy balances}

Electricity generation by fuel

Source: International Energy Agency (IEA), $2006{ }^{28}$

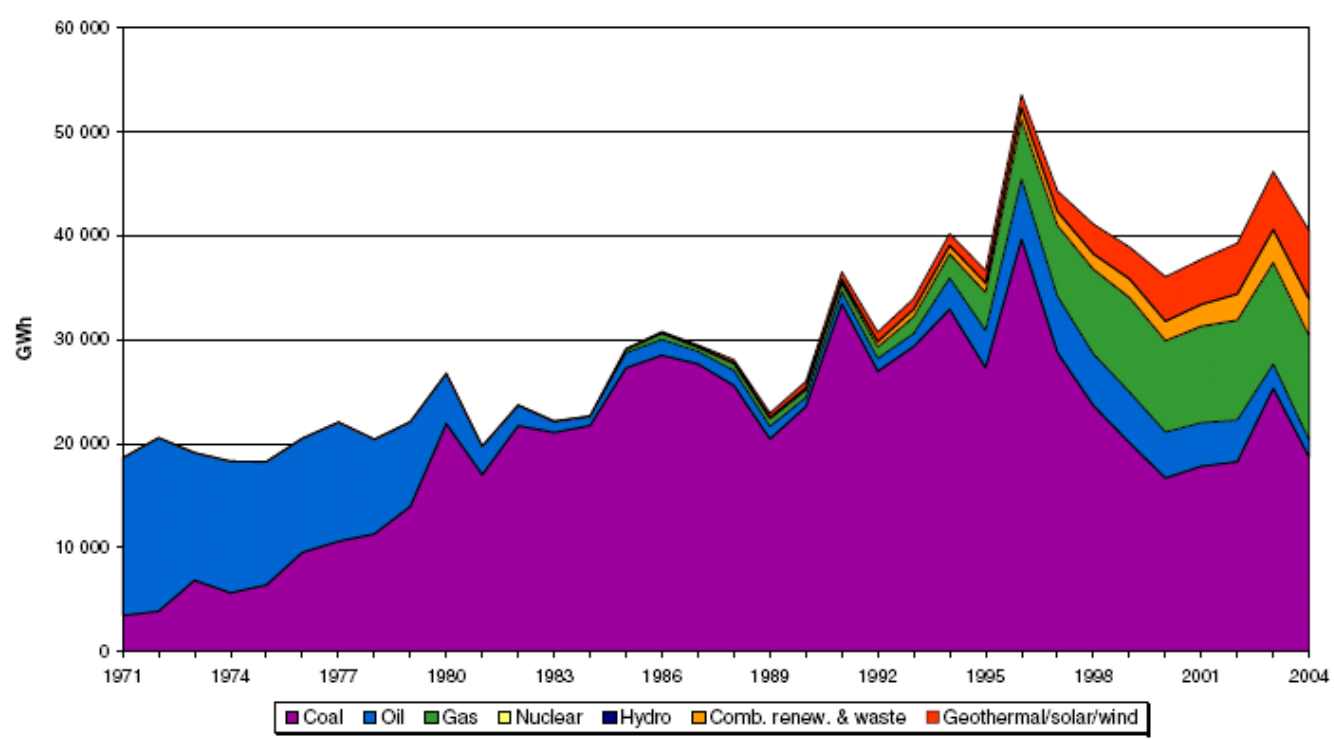

Figure 36: Denmark's electricity generation by fuel from 1971 to 2004

[source: IEA, 2006]

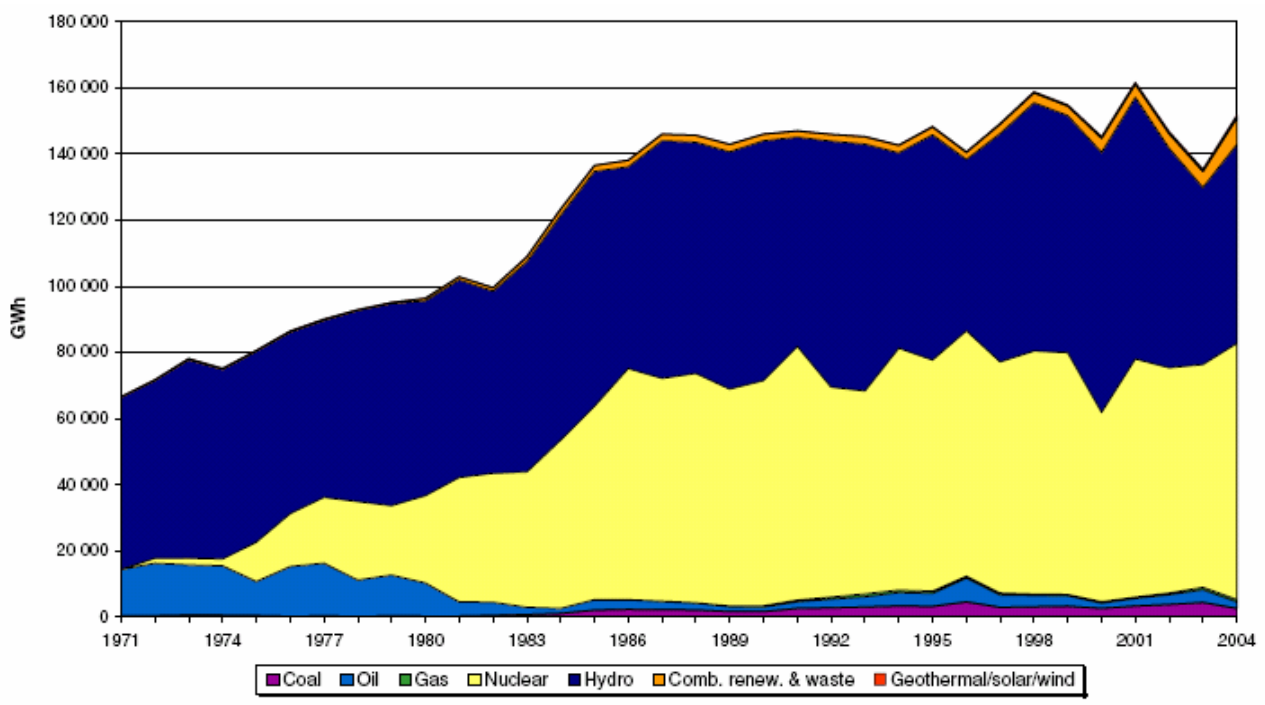

Figure 37: Sweden's electricity generation by fuel from 1971 to 2004 [source: IEA, 2006]

\footnotetext{
${ }^{28}$ http://www.iea.org/Textbase/stats/index.asp
} 


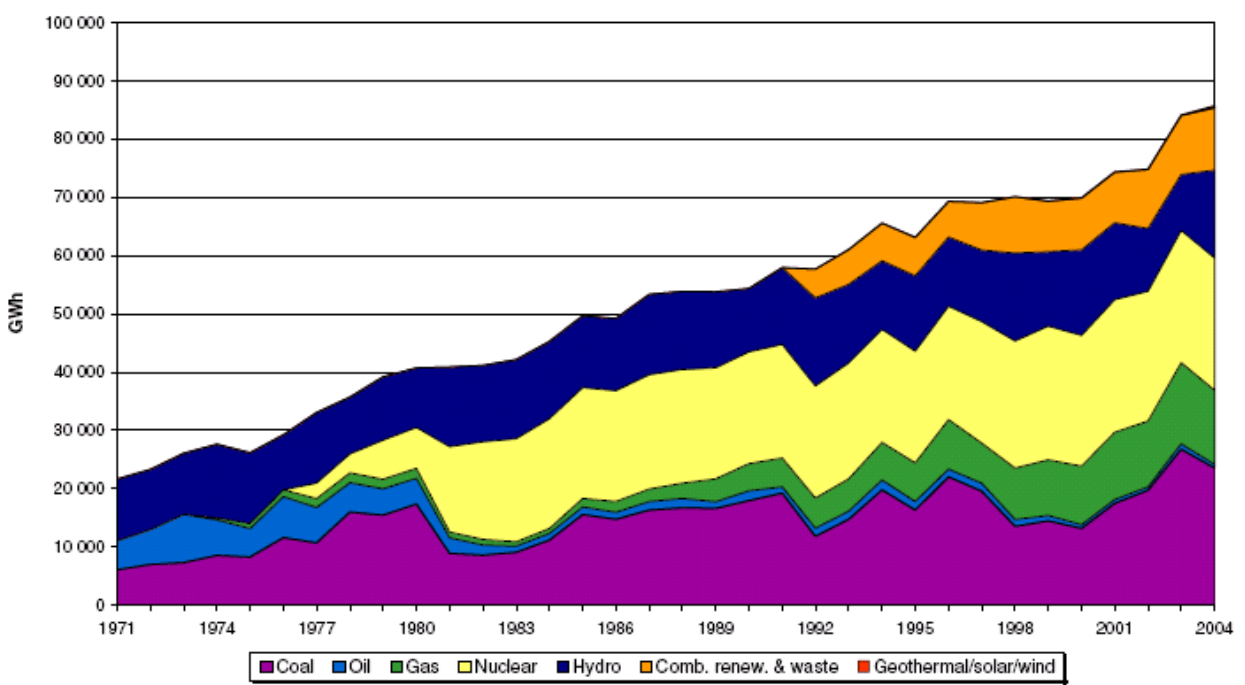

Figure 38: Finland's electricity generation by fuel from 1971 to 2004 [source: IEA, 2006]

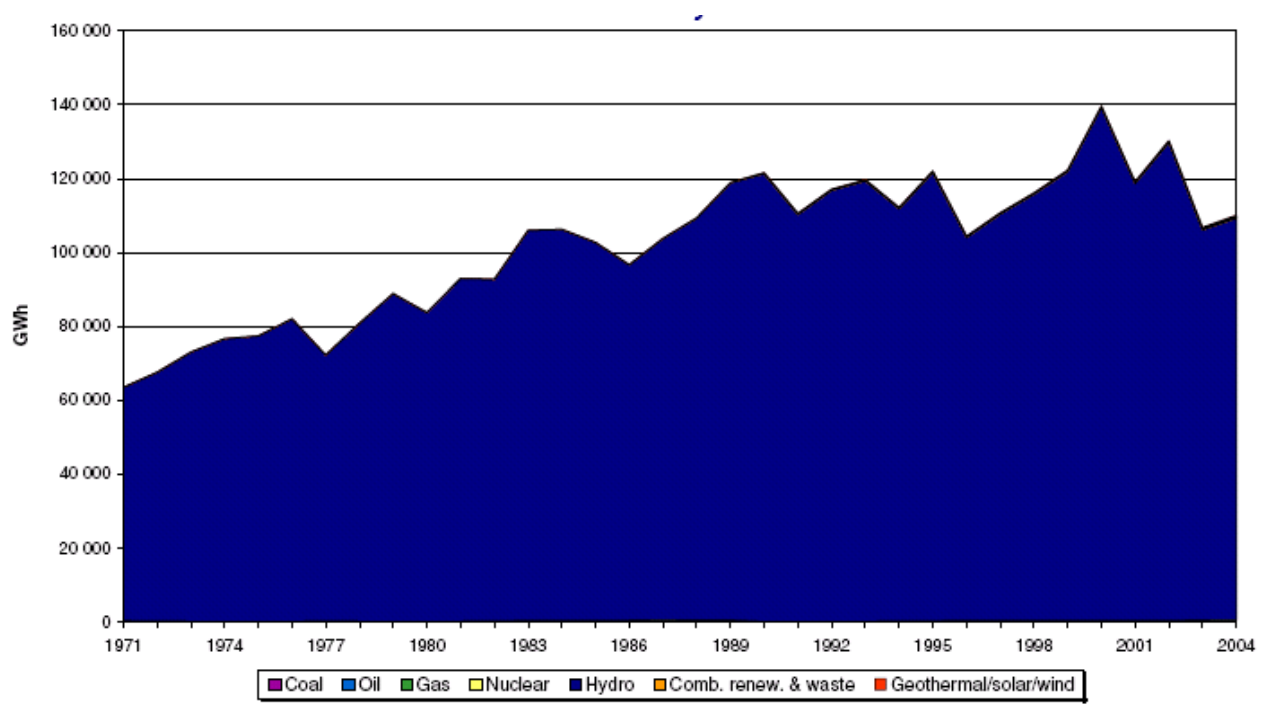

Figure 39: Norway's electricity generation by fuel from 1971 to 2004

[source: IEA, 2006] 


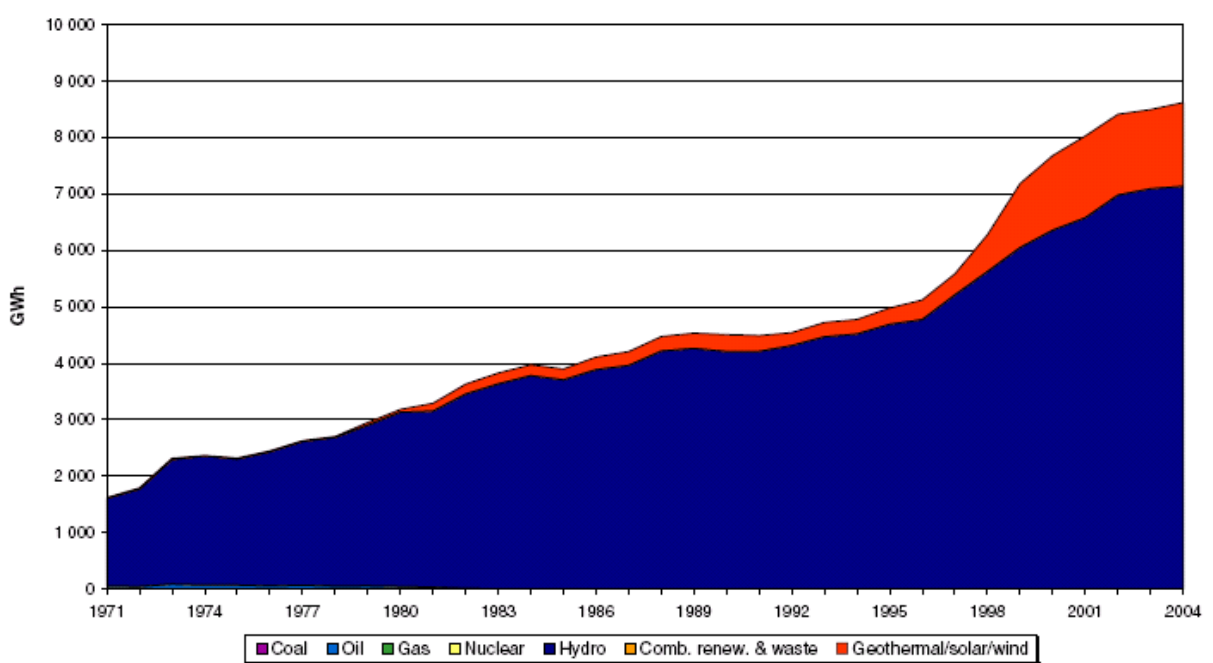

Figure 40: Iceland's electricity generation by fuel from 1971 to 2004 [source: IEA, 2006]

\section{Final energy consumption by sectors}

Source: Eurostat, $2007^{29}$

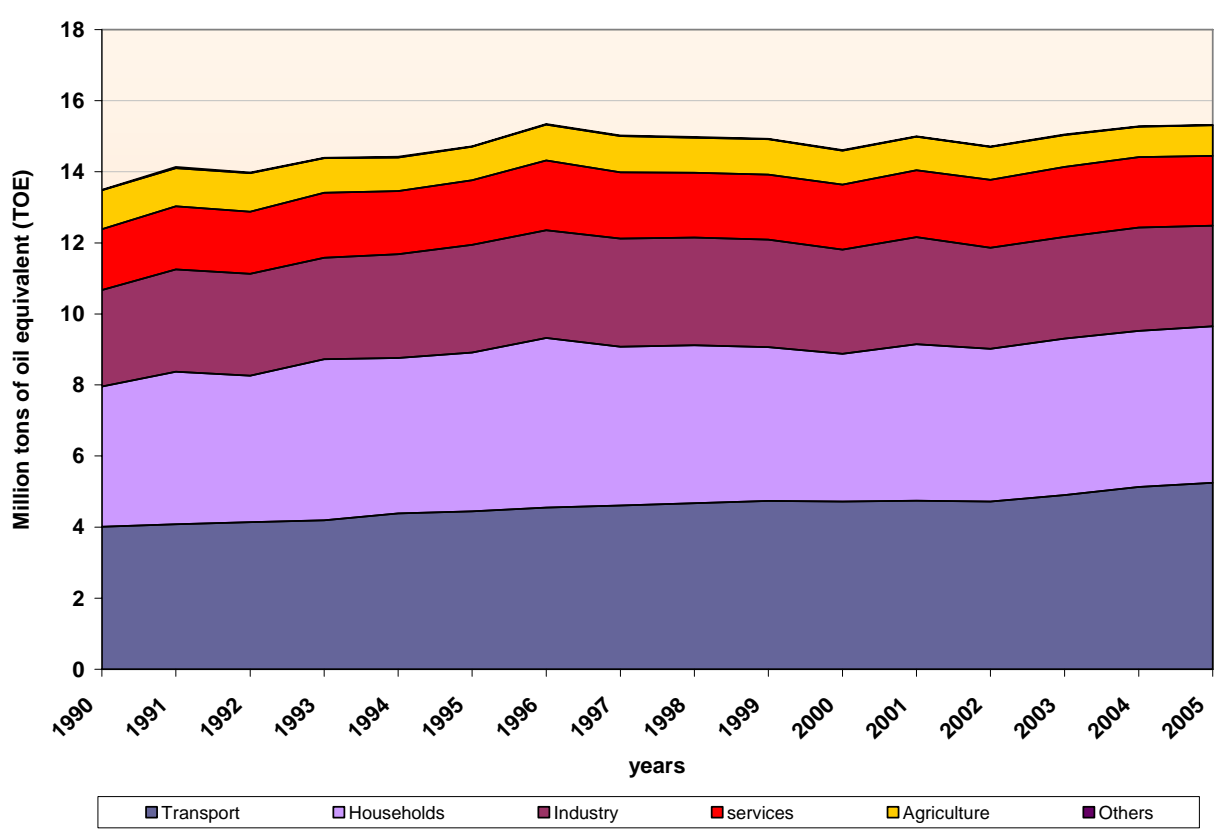

Figure 40: Denmark, final energy consumption, 1990 - 2005, [source: Eurostat, 2007]

${ }^{29} \mathrm{http} / / /$ epp.eurostat.ec.europa.eu/portal/page?_pageid=0,1136239,0_45571447\&_dad=portal\&_s chema=PORTAL 


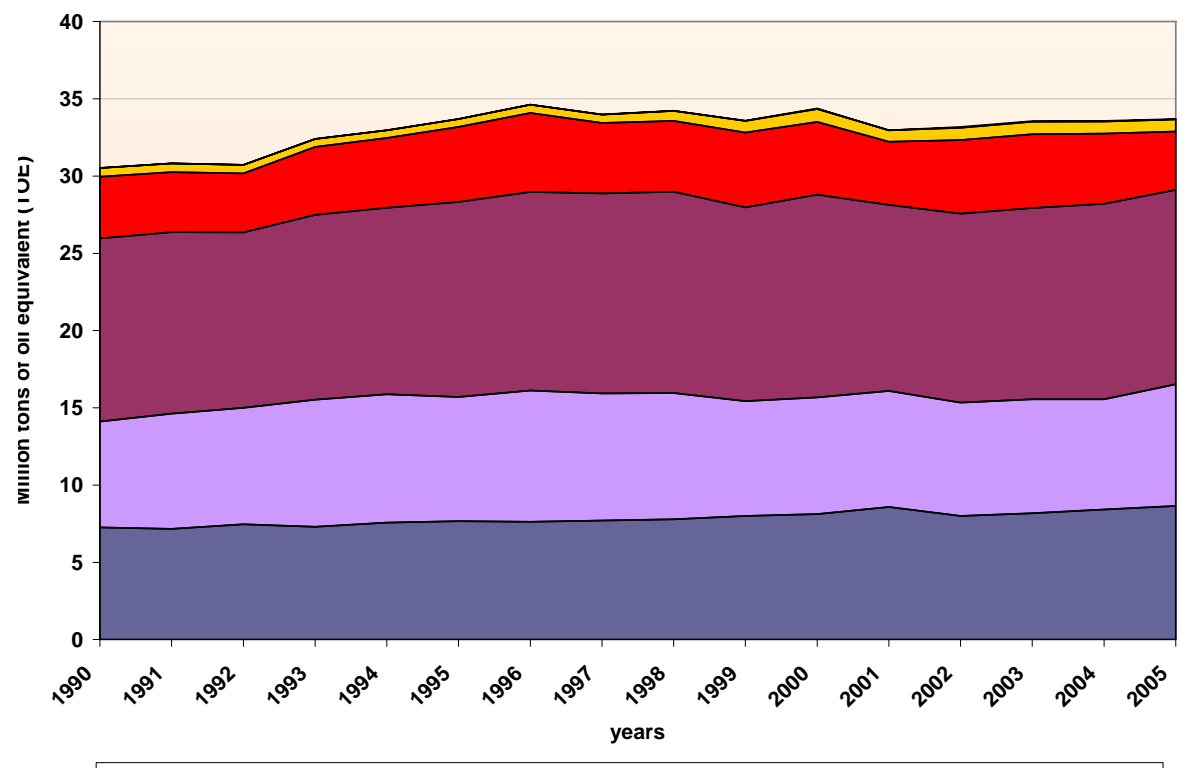

Figure 41: Sweden, final energy consumption, 1990 - 2005, [source: Eurostat, 2007]

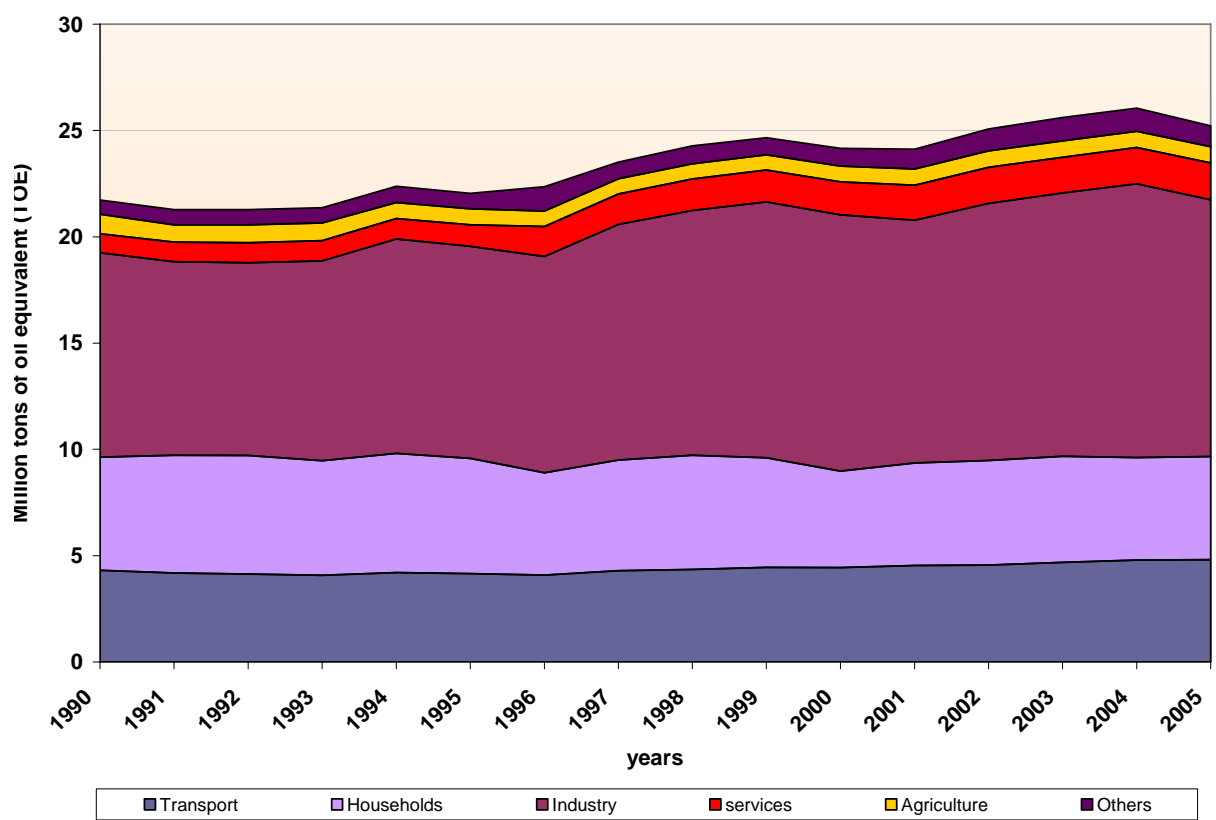

Figure 42: Finland, final energy consumption, 1990 - 2005. [source: Eurostat, 2007] 


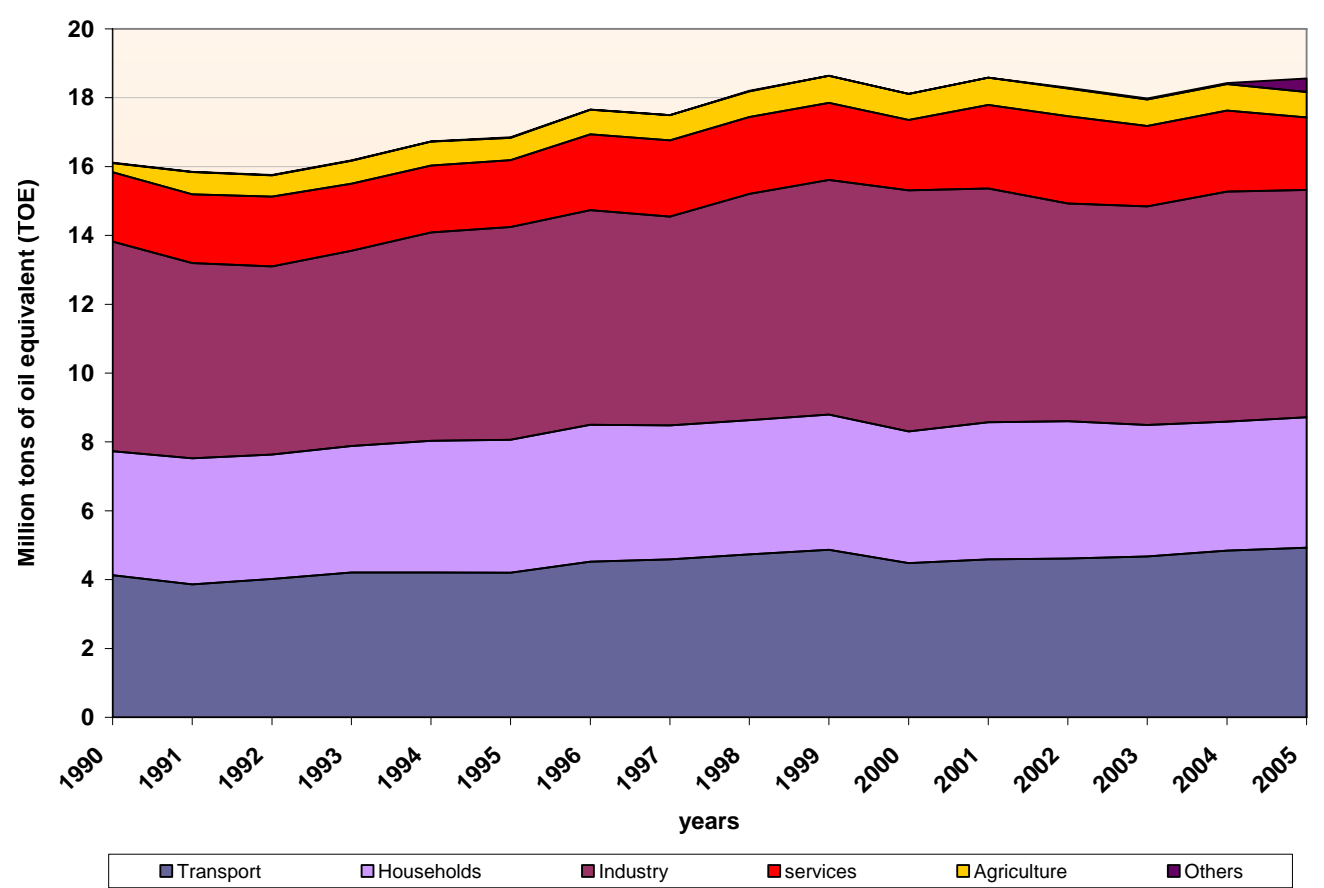

Figure 43: Norway, final energy consumption, 1990 - 2005.

Source: Eurostat, 2007

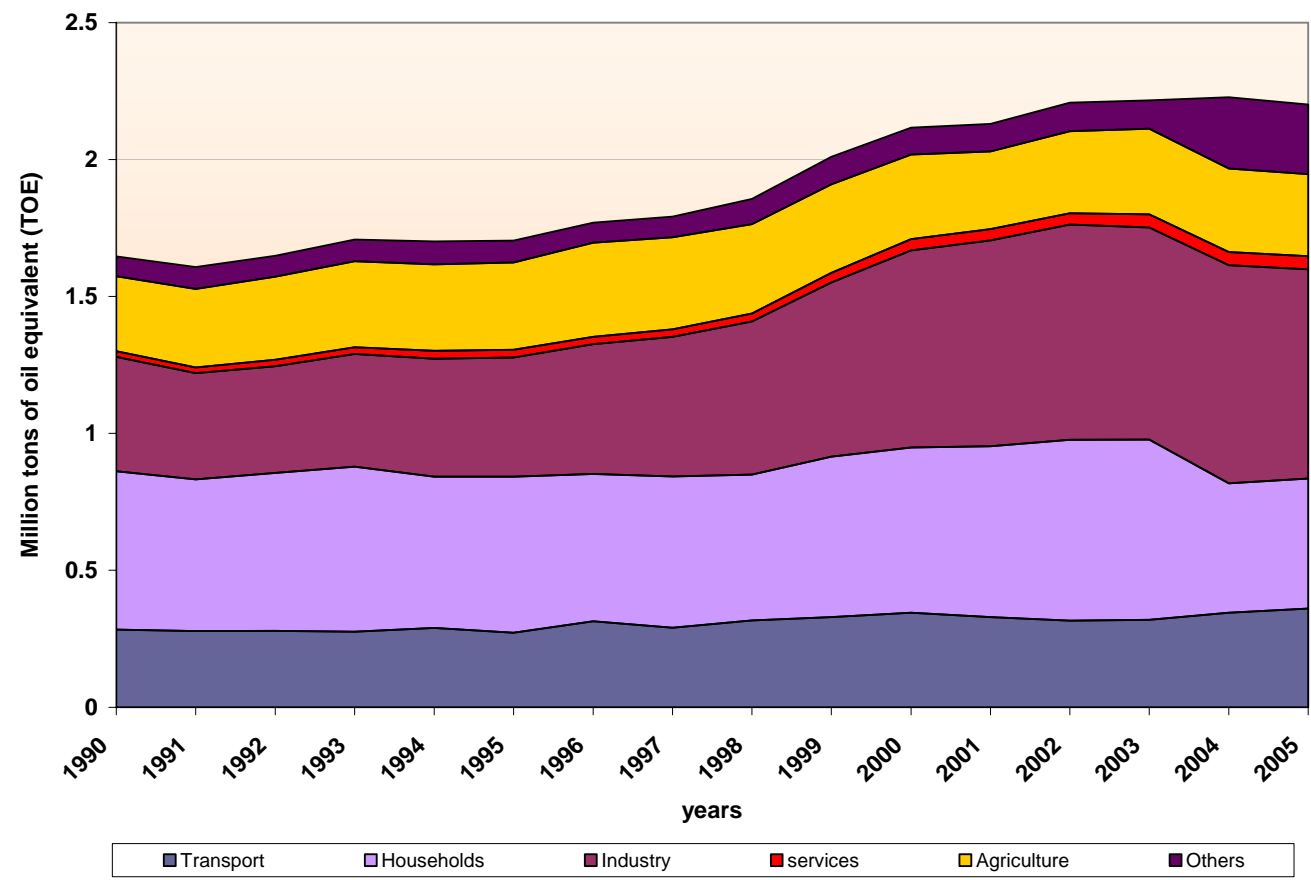

Figure 44: Iceland, final energy consumption, 1990 - 2005,

Source: Eurostat, 2007 
Electricity consumption per sector, total production and net imports

Source: Eurostat, 2007

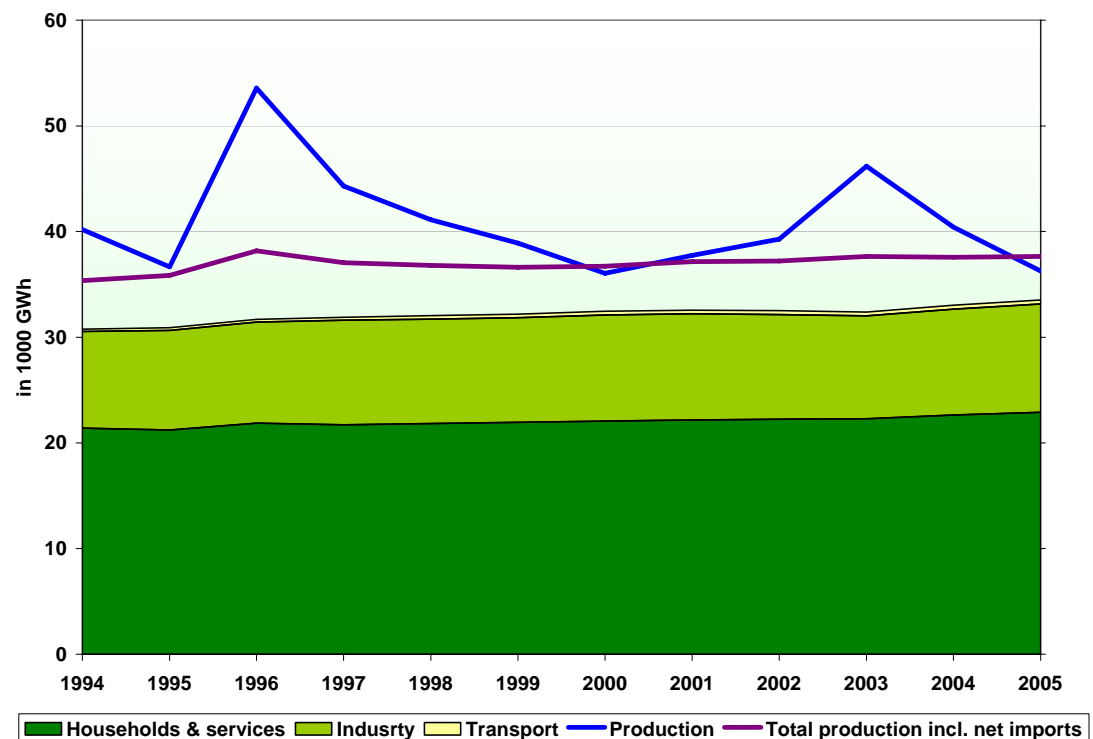

Figure 45: Denmark, electricity consumption per sector \& total production 1994-2005. [source: EUROSTAT 2007]

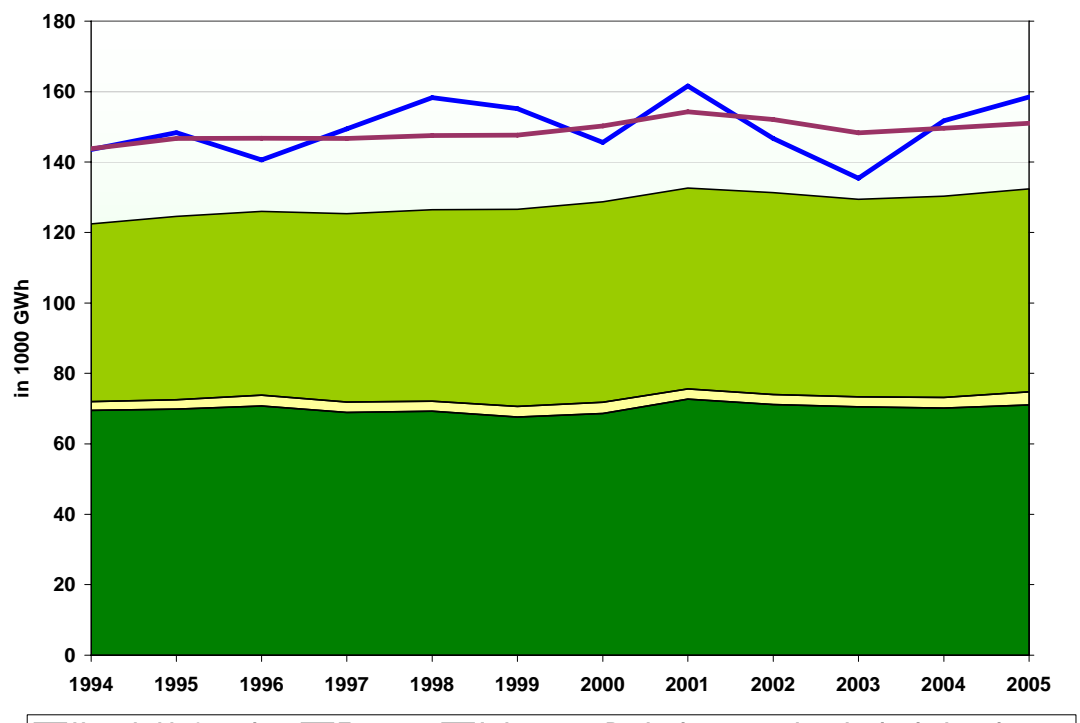

$\square$ Households \& services $\square$ Transport $\square$ Indusrty $\square$ Poduction — total production incl. net inpons

Figure 46: Sweden, electricity consumption per sector \& total production 1994-2005. [Source: EUROSTAT 2007] 


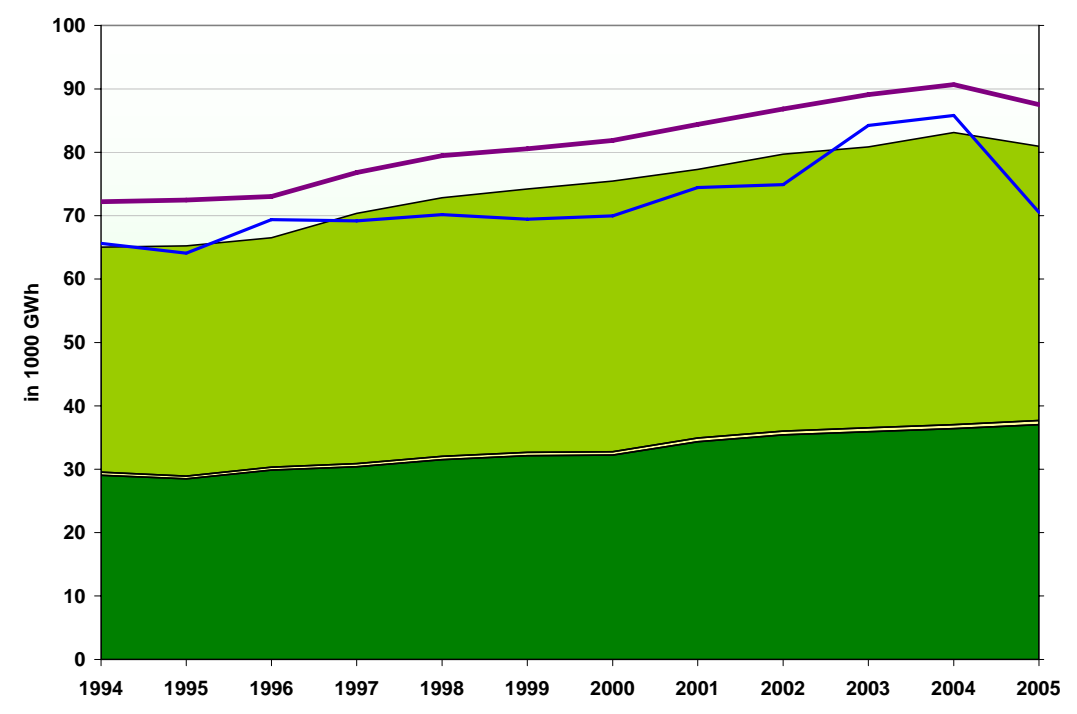

$\square$ Households \& services $\square$ Transport $\square$ Industry — Production — Total production incl. net imports

Figure 47: Finland, electricity consumption per sector \& total production 1994-2005 [source: EUROSTAT 2007]

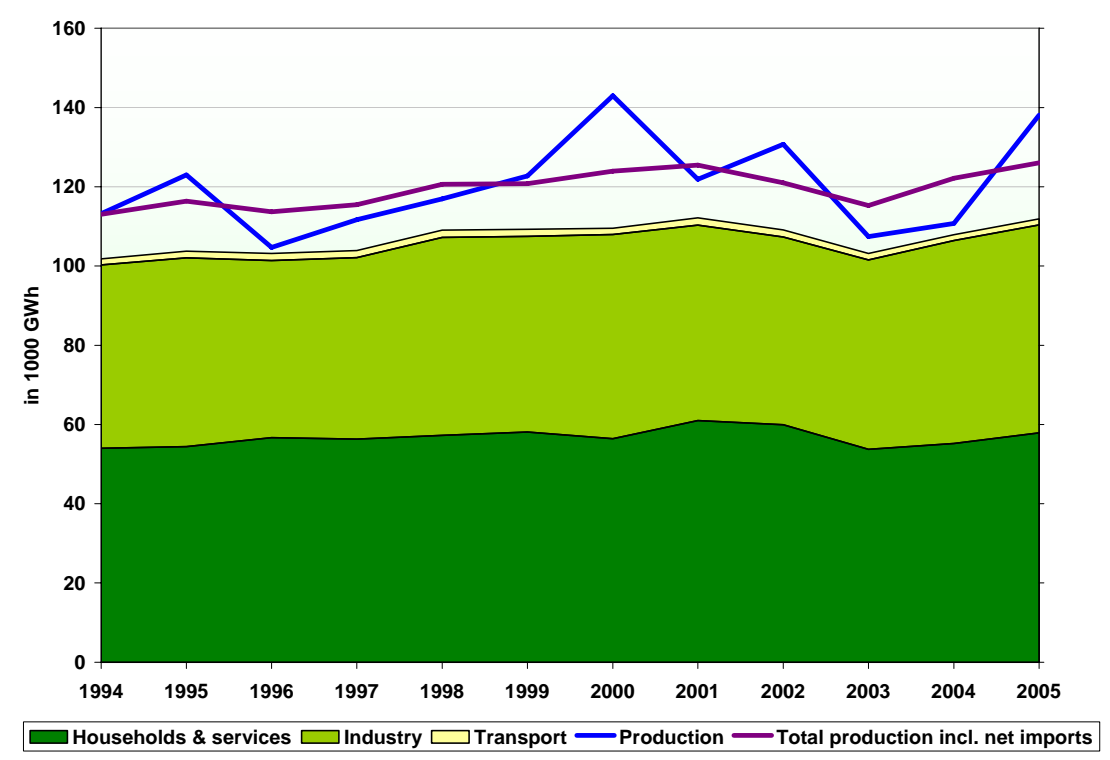

Figure 48: Norway, electricity consumption per sector \& total production 1994-2005. [source: EUROSTAT 2007] 


\section{Primary energy production and consumption}

Source: Eurostat, 2007

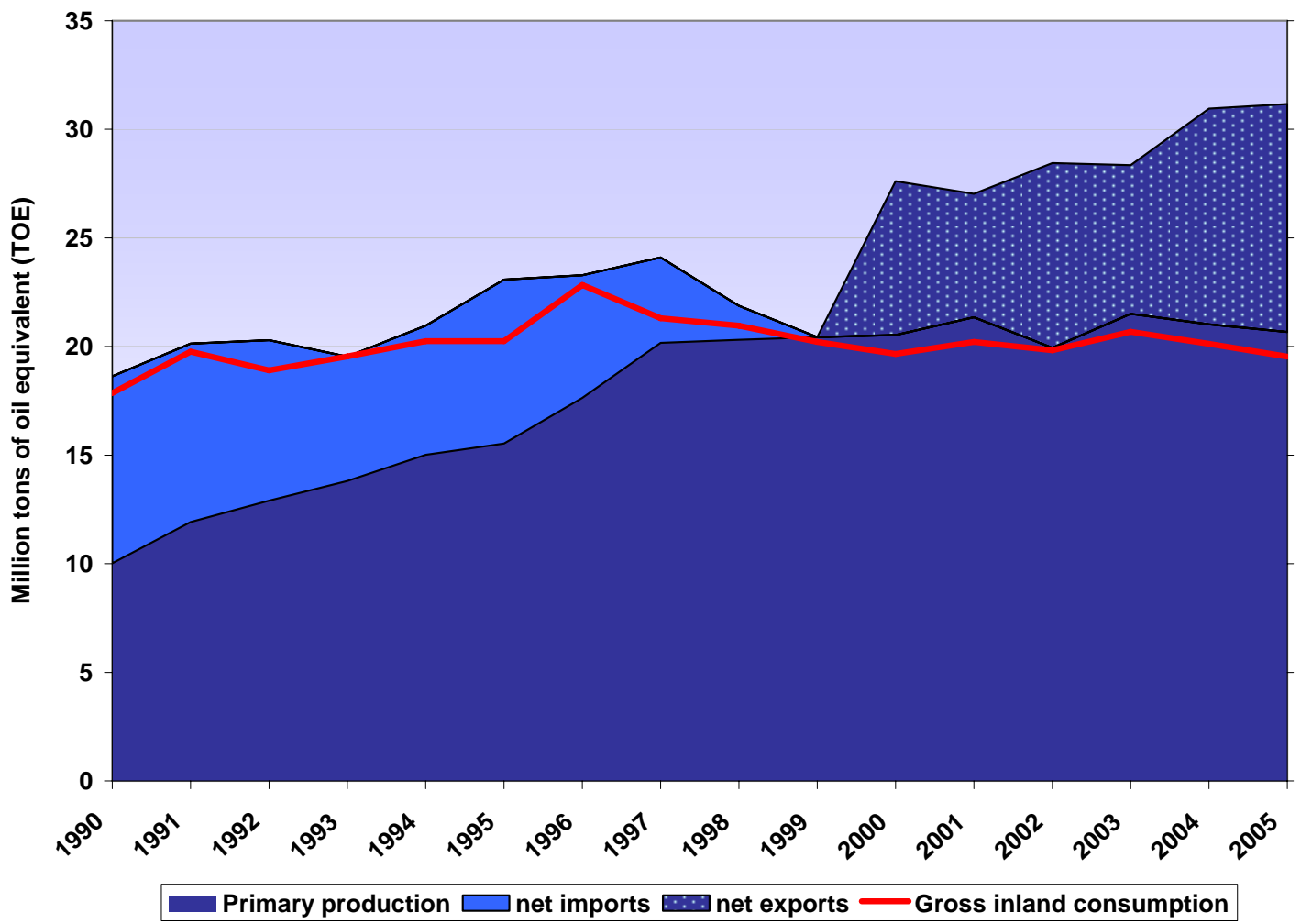

Figure 49: Denmark, Primary energy production, 1990- 2005, [source: Eurostat, 2007]

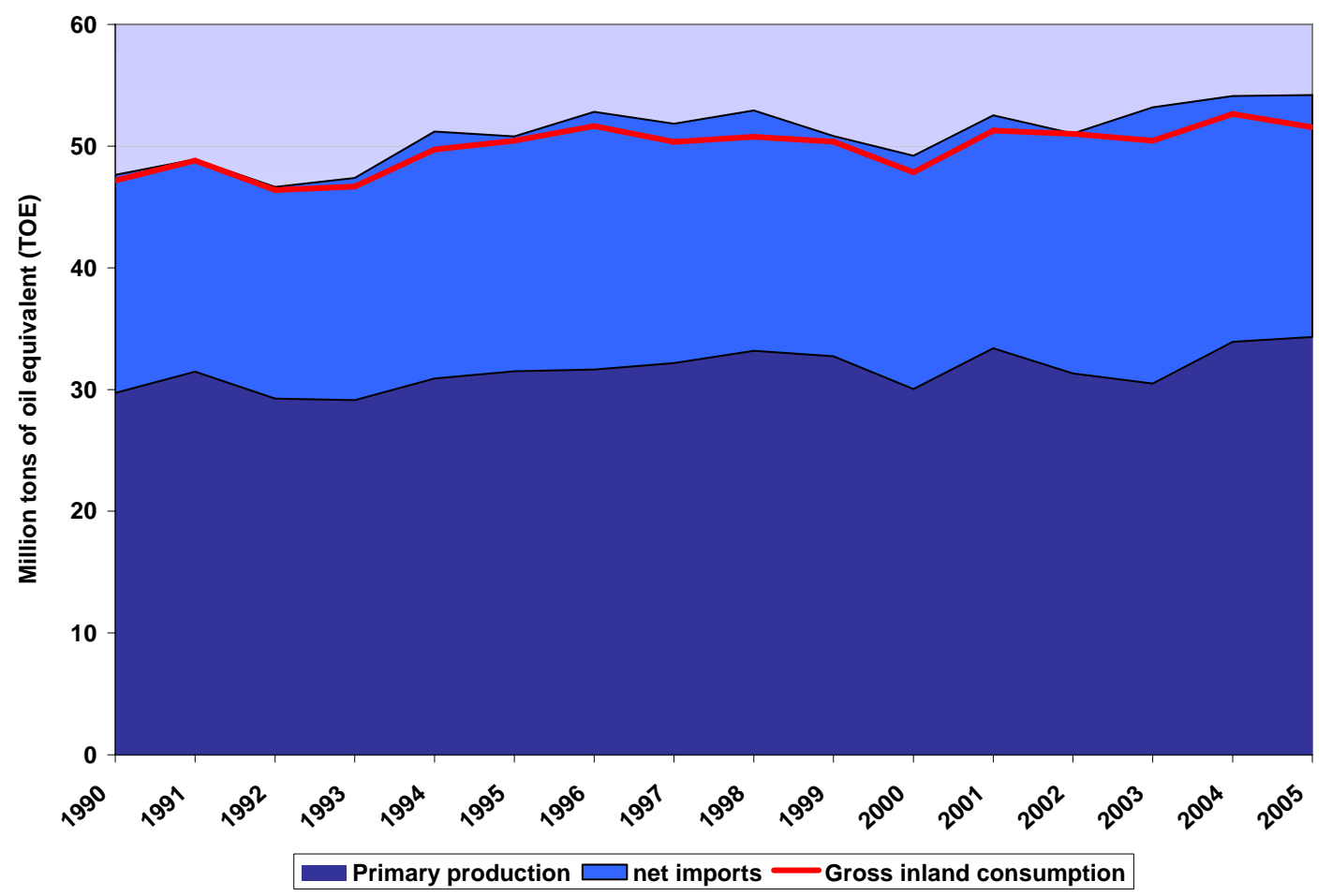

Figure 50: Sweden, Primary energy production, 1990-2005, [source: Eurostat, 2007] 


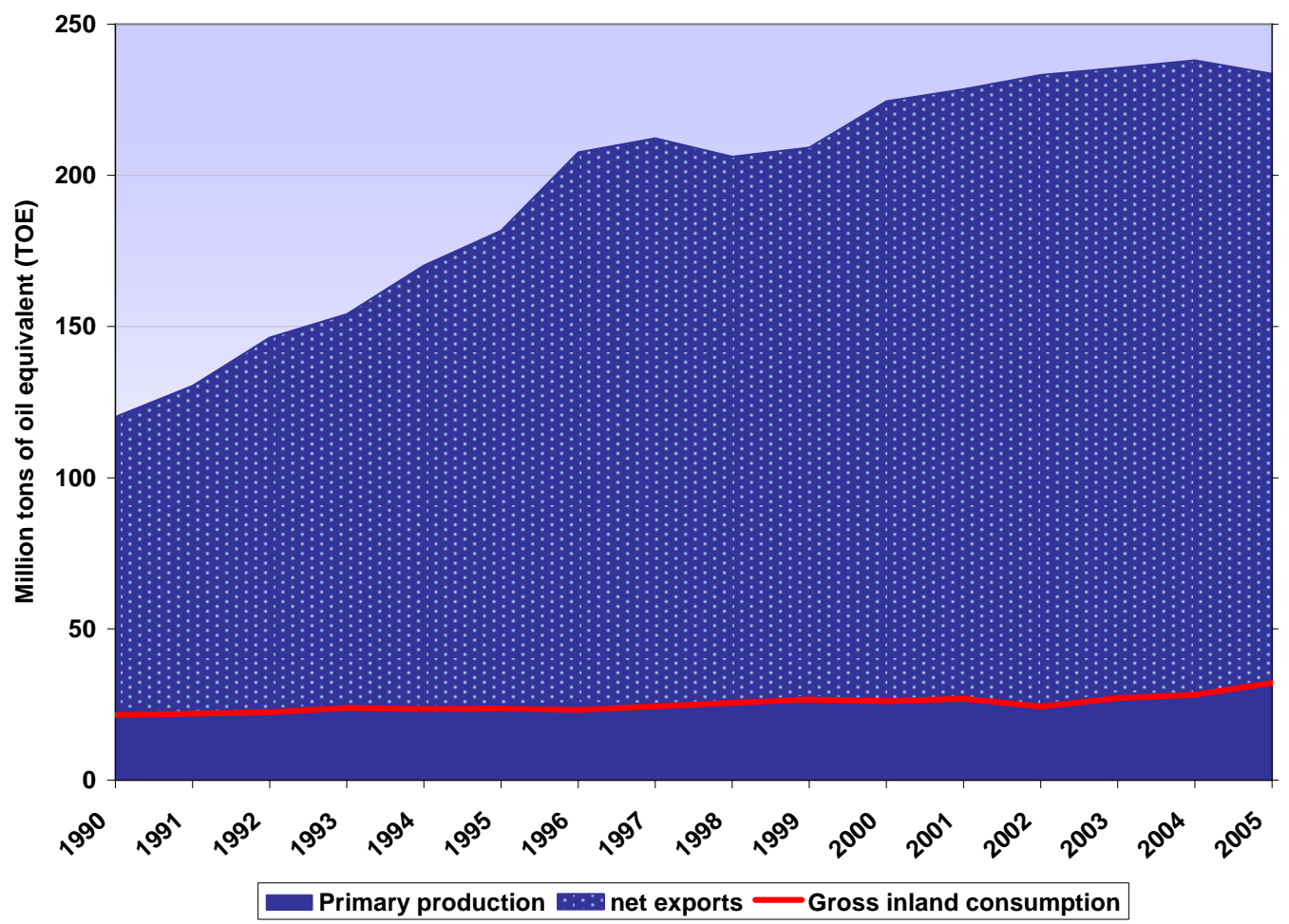

Figure 51: Norway, Primary energy production, 1990 - 2005, [source: Eurostat, 2007]

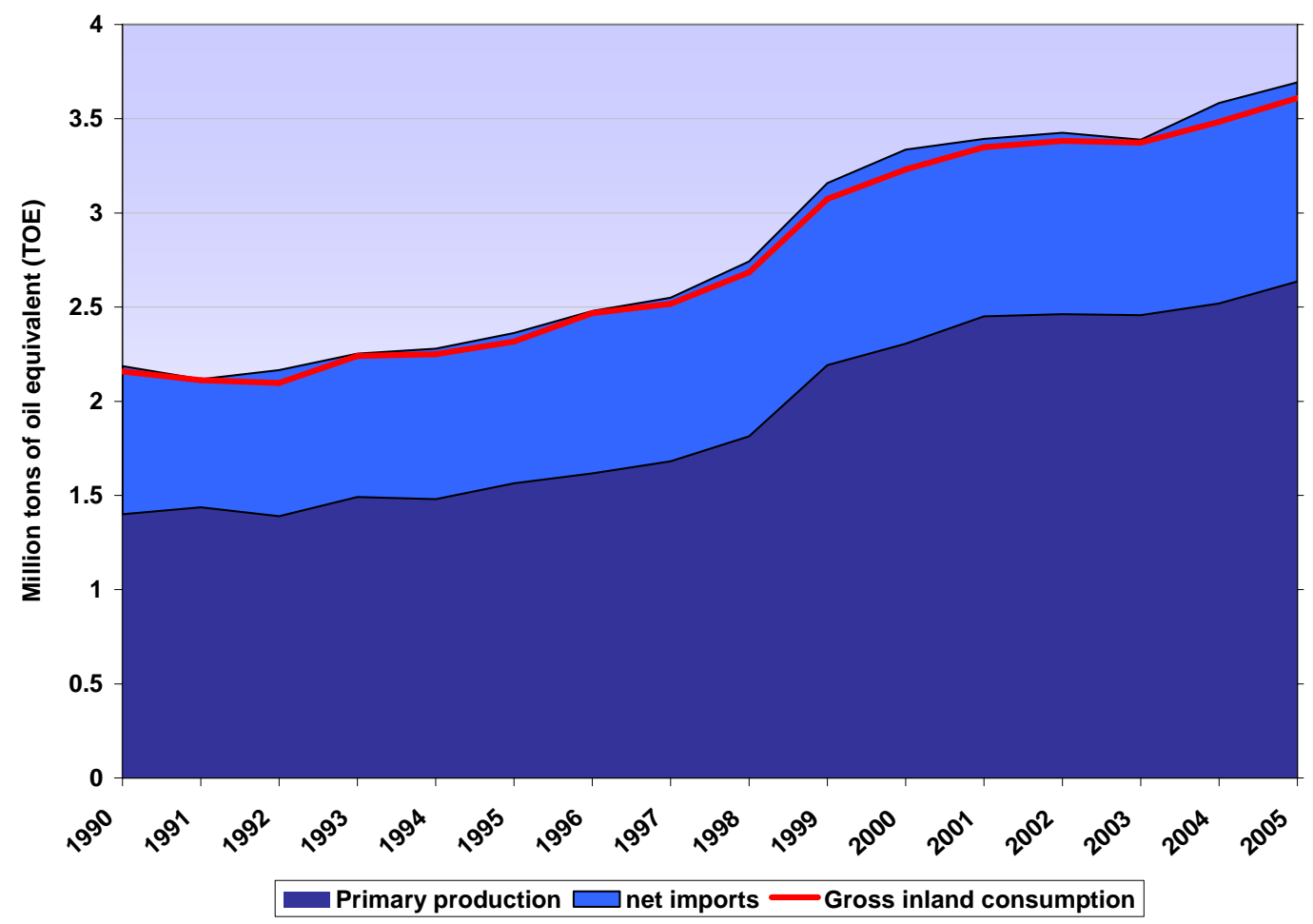

Figure 52: Iceland, Primary energy production, 1990 - 2005, [source: Eurostat, 2007] 


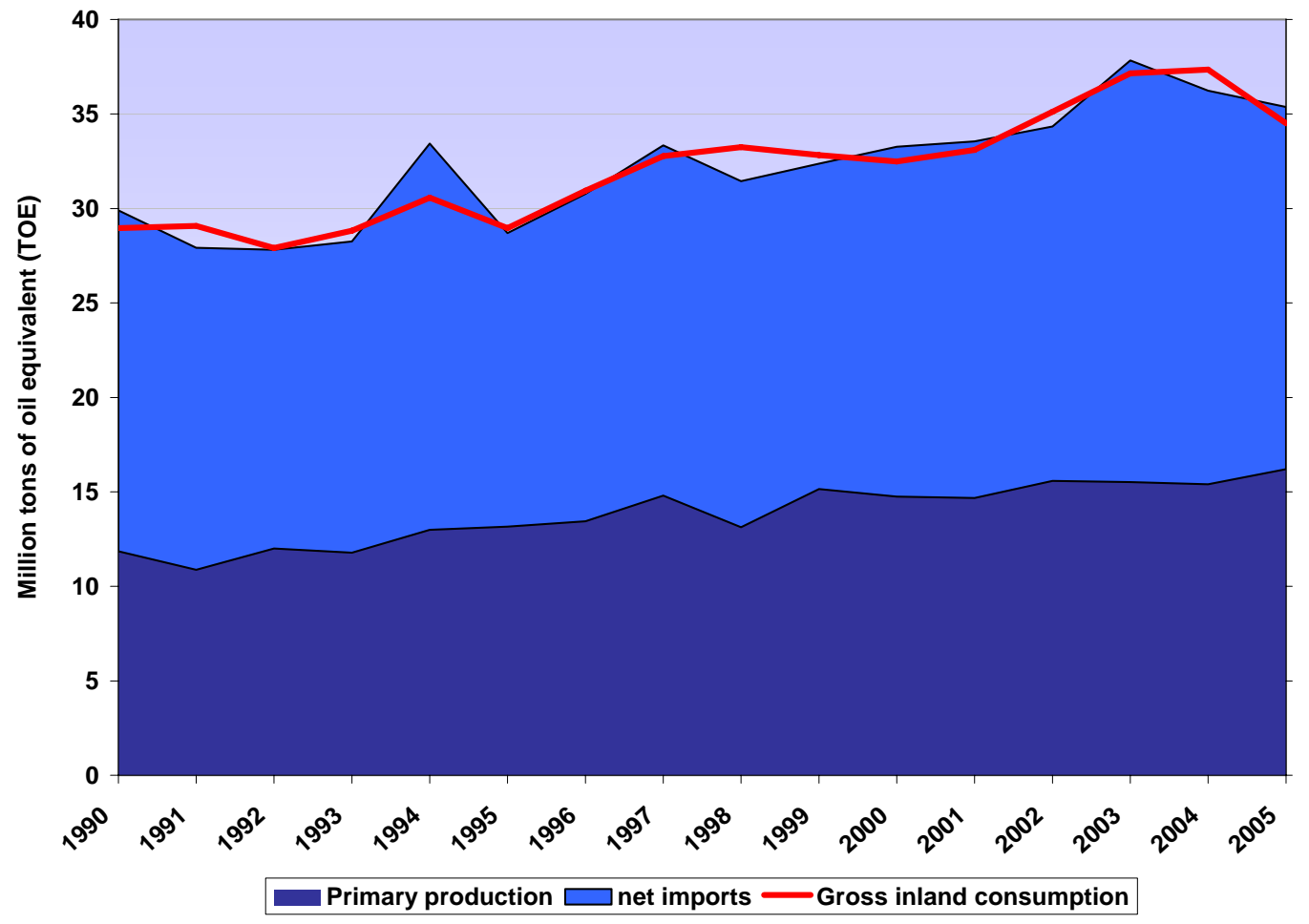

Figure 53: Sweden, Primary energy production, 1990 - 2005, [source: Eurostat, 2007] 
Table 15 Electricity generation, consumption and trade in the Nordic countries.

\begin{tabular}{|c|c|c|c|c|c|c|c|c|c|c|c|c|}
\hline $\begin{array}{l}\text { Total } \\
\text { Production }\end{array}$ & 1994 & 1995 & 1996 & 1997 & 1998 & 1999 & 2000 & 2001 & 2002 & 2003 & 2004 & 2005 \\
\hline DK & 40191 & 36655 & 53577 & 44311 & 41110 & 38917 & 36049 & 37726 & 39283 & 46180 & 40432 & 36276 \\
\hline NO & 113213 & 123011 & 104712 & 111656 & 116986 & 122722 & 143028 & 121890 & 130705 & 107405 & 110699 & 138108 \\
\hline SW & 143571 & 148379 & 140633 & 149422 & 158275 & 155158 & 145585 & 161617 & 146733 & 135435 & 151727 & 158435 \\
\hline $\mathrm{FI}$ & 65642 & 64064 & 69372 & 69176 & 70170 & 69433 & 69989 & 74450 & 74899 & 84230 & 85817 & 70549 \\
\hline IS & 4780 & 4981 & 5123 & 5586 & 6281 & 7188 & 7684 & 8033 & 8416 & 8500 & 8623 & 8686 \\
\hline \multicolumn{13}{|c|}{ Consumption } \\
\hline \multicolumn{13}{|l|}{ Industry } \\
\hline DK & 9140 & 9432 & 9560 & 9890 & 9905 & 9897 & 10049 & 10059 & 9924 & 9728 & 10043 & 10261 \\
\hline NO & 46293 & 47671 & 44695 & 45818 & 50001 & 49376 & 51566 & 49324 & 47397 & 47763 & 51277 & 52467 \\
\hline SW & 50476 & 52013 & 52169 & 53496 & 54369 & 55971 & 56938 & 57119 & 57273 & 56107 & 57194 & 57558 \\
\hline $\mathrm{FI}$ & 35528 & 36274 & 36166 & 39477 & 40773 & 41520 & 42674 & 42384 & 43668 & 44306 & 46111 & 43261 \\
\hline IS & 2730 & 2847 & 2973 & 3355 & 3991 & 4798 & 5240 & 5519 & 5822 & 5867 & 5917 & 5889 \\
\hline \multicolumn{13}{|l|}{ Transport } \\
\hline DK & 226 & 237 & 257 & 282 & 325 & 341 & 348 & 348 & 364 & 353 & 370 & 375 \\
\hline NO & 1545 & 1681 & 1786 & 1791 & 1844 & 1795 & 1542 & 1890 & 1804 & 1660 & 1476 & 1547 \\
\hline SW & 2469 & 2718 & 3067 & 2955 & 2796 & 3016 & 3194 & 2862 & 2867 & 2838 & 2989 & 3816 \\
\hline \multicolumn{13}{|c|}{$\begin{array}{l}\text { Households/ } \\
\text { services }\end{array}$} \\
\hline DK & 21394 & 21213 & 21865 & 21704 & 21813 & 21942 & 22057 & 22158 & 22227 & 22289 & 22615 & 22878 \\
\hline NO & 53966 & 54414 & 56663 & 56288 & 57212 & 58096 & 56425 & 60974 & 59912 & 53731 & 55162 & 57901 \\
\hline SW & 69520 & 69842 & 70768 & 68910 & 69274 & 67593 & 68593 & 72692 & 71139 & 70498 & 70178 & 70999 \\
\hline $\mathrm{FI}$ & 29043 & 28478 & 29879 & 30389 & 31518 & 32160 & 32234 & 34347 & 35419 & 35922 & 36387 & 37026 \\
\hline IS & 1442 & 1412 & 1323 & 1357 & 1510 & 1585 & 1671 & 1693 & 1697 & 1674 & 1843 & 1910 \\
\hline \multicolumn{13}{|l|}{ Net imports } \\
\hline DK & -4840 & -794 & -15401 & -7252 & -4320 & -2313 & 665 & -575 & -2071 & -8545 & -2872 & 1369 \\
\hline NO & -132 & -6666 & 8976 & 3818 & 3634 & -1919 & -19055 & 3571 & -9711 & 7874 & 11455 & -12043 \\
\hline SW & 261 & -1681 & 6139 & -2708 & -10697 & -7482 & 4678 & -7290 & 5356 & 12830 & -2104 & -7392 \\
\hline $\mathrm{FI}$ & 6541 & 8405 & 3661 & 7653 & 9306 & 11124 & 11880 & 9959 & 11925 & 4852 & 4870 & 16989 \\
\hline
\end{tabular}

